\title{
The Trafficking of the Water Channel Aquaporin-2 in Renal Principal Cells - a Potential Target for Pharmacological Intervention in Cardiovascular Diseases
}

\section{OPEN ACCESS}

Edited by:

Vsevolod V. Gurevich, Vanderbilt University, USA

Reviewed by:

Yanyong Kang,

Van Andel Institute, USA

Qiuyan Chen,

Vanderbilt University, USA

*Correspondence:

Enno Klussmann

enno.klussmann@mdc-berlin.de

${ }^{\dagger}$ These authors have contributed equally to this work.

Specialty section:

This article was submitted to

Experimental Pharmacology and Drug

Discovery,

a section of the journal

Frontiers in Pharmacology

Received: 18 December 2015

Accepted: 25 January 2016

Published: 11 February 2016

Citation:

Vukićević T, Schulz M, Faust $D$ and Klussmann E (2016) The Trafficking of the Water Channel Aquaporin-2 in Renal Principal Cells - a Potential

Target for Pharmacological

Intervention in Cardiovascular

Diseases. Front. Pharmacol. 7:23.

doi: 10.3389/fphar.2016.00023

\author{
Tanja Vukićević ${ }^{1+}$, Maike Schulz ${ }^{1+}$, Dörte Faust ${ }^{1}$ and Enno Klussmann ${ }^{1,2 *}$ \\ ${ }^{1}$ Max Delbrück Center for Molecular Medicine (MDC) in the Helmholtz Association, Berlin, Germany, ${ }^{2}$ German Centre for \\ Cardiovascular Research, Berlin, Germany
}

Arginine-vasopressin (AVP) stimulates the redistribution of water channels, aquaporin-2 (AQP2) from intracellular vesicles into the plasma membrane of renal collecting duct principal cells. By this AVP directs 10\% of the water reabsorption from the $170 \mathrm{~L}$ of primary urine that the human kidneys produce each day. This review discusses molecular mechanisms underlying the AVP-induced redistribution of AQP2; in particular, it provides an overview over the proteins participating in the control of its localization. Defects preventing the insertion of AQP2 into the plasma membrane cause diabetes insipidus. The disease can be acquired or inherited, and is characterized by polyuria and polydipsia. Vice versa, up-regulation of the system causing a predominant localization of AQP2 in the plasma membrane leads to excessive water retention and hyponatremia as in the syndrome of inappropriate antidiuretic hormone secretion (SIADH), late stage heart failure or liver cirrhosis. This article briefly summarizes the currently available pharmacotherapies for the treatment of such water balance disorders, and discusses the value of newly identified mechanisms controlling AQP2 for developing novel pharmacological strategies. Innovative concepts for the therapy of water balance disorders are required as there is a medical need due to the lack of causal treatments.

Keywords: AQP2, AVP, AKAP, PKA, CAMP, NDI, heart failure, SIADH

\section{INTRODUCTION}

The kidney has multiple functions including excretion of toxins, control of blood pressure and $\mathrm{pH}$. One of its main functions is water reabsorption from primary urine. The kidney generates more than $170 \mathrm{~L}$ of primary urine per day by ultrafiltration of the blood. This huge volume, mainly water, of course needs to be reduced to prevent dehydration. Indeed, only around $1 \%$ of the volume is excreted as urine. How does the kidney achieve this?

The functional unit of the kidney is the nephron, of which there are around 1-2 million per kidney. A nephron is a tubular system consisting of several functionally distinct segments. The initial unit is the glomerulus where the blood is filtered at a rate of $\sim 120 \mathrm{ml} / \mathrm{min}$ into the surrounding Bowman's capsule. The filtrate flows from there through the proximal convoluted tubule, the descending and ascending limb of Henle, the distal convoluted tubule, and the collecting duct into the bladder. During the passage the volume of the filtrate is reduced and its composition altered. As the final urine, the filtrate reaches the bladder where it is stored until it is cleared. 


\section{RENAL WATER CHANNELS: EXPRESSION PATTERN AND FUNCTIONS}

The concentration of the filtrate is achieved mainly by aquaporins (AQPs) that allow diffusion of water across membranes. The water flow is driven by an osmotic gradient established by sodium across the kidney.

There are 13 mammalian AQPs, AQP0-AQP12, that show high structural similarity. They all contain six transmembrane domains, which form a water pore characterized by a dual NPA motif (Preston et al., 1992; Jung et al., 1994; Kosinska Eriksson et al., 2013). All AQPs assemble into homotetramers. Nine AQPs (AQP1-8 and AQP11) are expressed along the nephron with distinct localization to particular segments (Table 1). Crucial roles in water reabsorption from primary urine play AQP14. AQP1 in the plasma membrane of epithelial cells facing the lumen of the proximal tubule and descending limb of Henle facilitates reabsorption of $80-90 \%$ of water from the filtrate (Nielsen et al., 1993; Schnermann et al., 1998). The ascending limb of Henle is impermeable for water due to the lack of AQPs. From the distal convoluted tubule throughout the collecting duct AQP3 and 4 are constitutively expressed in the basolateral plasma membrane (Ecelbarger et al., 1995; Terris et al., 1995). Thus the apical plasma membrane is water impermeable. However, in the collecting duct the principal cells additionally express $\mathrm{AQP} 2$. It resides on intracellular vesicles under resting conditions. Stimulation of vasopressin V2 receptors (V2R) on the basolateral surface of the cells with arginine-vasopressin (AVP) causes a redistribution of AQP2 predominantly into the apical plasma membrane (Figure 1). The insertion facilitates water reabsorption of around $10 \%$ of the water from the remaining filtrate (Fushimi et al., 1993; Katsura et al., 1995; Nielsen et al., 2002). In total, the reabsorption of water by AQPs accounts for the reduction of the volume of the initial filtrate from $170 \mathrm{~L}$ to around 2-4 L/day of final urine that is on average excreted by an adult.

This review focuses on mechanisms controlling the localization of AQP2 and the value of such control mechanisms as pharmacological targets in cardiovascular diseases.

\section{AVP STIMULATES THE REDISTRIBUTION OF AQP2 FROM INTRACELLULAR VESICLES INTO THE PLASMA MEMBRANE}

The modulation of the final $10 \%$ of water reabsorption in the collecting duct fine-tunes body water homeostasis. Osmoreceptors in the hypothalamus detect changes in blood osmolality that arise, for example, from hypernatremia and hypovolemia, and induce the release of the peptide hormone AVP (antidiuretic hormone) (Verney, 1947; Hayashi et al., 1994). AVP is synthesized in the hypothalamus as a preprohormone. It is released to the pituitary gland and secreted from there to stimulate renal collecting duct principal cells to retain water. As a result, blood volume increases, osmolality decreases, and osmoreceptor signaling declines.
The primary regulator of blood pressure is the reninangiotensin-aldosterone system (RAAS). Hypotension or hypovolemia induce renin secretion from renal juxtaglomerular cells. Renin converts angiotensin I (Ang I) to angiotensin II (Ang II). AngII acts as a vasoconstrictor, and induces aldosterone and AVP secretion to stimulate renal sodium and water reabsorption. This increases blood volume and blood pressure. As a counterpart natriuretic peptides are secreted by cardiac myocytes upon hypervolemia-induced mechanical stretching of the atrial (atrial natriuretic peptide, ANP) and ventricular (brain natriuretic peptide, BNP) walls. The peptides have vasodilative, natriuretic and diuretic effects to lower blood volume and pressure.

At the molecular level, AVP binds to its cognate G proteincoupled receptor, the V2R, which is located in the basolateral plasma membrane of collecting duct principal cells (Figure 1). The binding of AVP to V2R activates the stimulatory $G$ protein, $\mathrm{G}_{\mathrm{s}}$. $\mathrm{G}_{\mathrm{s}}$, in turn activates adenylyl cyclases AC3 and AC6 to convert ATP to cyclic adenosine monophosphate (cAMP). One of the effectors of cAMP is protein kinase A (PKA). It consists of a dimer of regulatory subunits (RI $\alpha, \mathrm{RI} \beta, \mathrm{RII} \alpha$, or RII $\beta$ ) and two catalytic subunits $(\mathrm{C} \alpha, \mathrm{C} \beta, \mathrm{C} \gamma$, or PrKX) each bound to one $\mathrm{R}$ subunit. Upon binding of cAMP to two sites in the R subunits PKA undergoes a conformational change and the $\mathrm{C}$ subunits are released. The free, and now active $\mathrm{C}$ subunits phosphorylate nearby targets. PKA phosphorylates serine 256 (S256) in the C terminus of AQP2.

AQP2 undergoes a constitutive recycling: its trafficking from intracellular vesicles into the plasma membrane and endocytic retrieval to its intracellular storage site is in dynamic equilibrium under resting conditions. The equilibrium is shifted toward plasma membrane insertion by the AVP-induced phosphorylation of S256 (Klussmann et al., 2000; Nedvetsky et al., 2009; Moeller et al., 2011). The finding that upon inhibition of endocytosis AQP2 accumulates in the apical plasma membrane of cultured cells regardless of AVP stimulation or S256 phosphorylation emphasizes the importance of the recycling pathway (Lu et al., 2004). It also shows that the redistribution of AQP2 can be induced independently of PKA activation (Nejsum et al., 2005). In addition to the phosphorylation status of S256 that of at least three further C-terminal residues of AQP2 changes in response to AVP stimulation (Fushimi et al., 1997; Katsura et al., 1997; Kamsteeg et al., 2000; Tamma et al., 2010): S261, S264, and S269. S261 is phosphorylated under resting conditions and found intracellularly; AVP triggers its dephosphorylation (Hoffert et al., 2007). In contrast, AVP induces the phosphorylation of S264 and S269 and thereby confers plasma membrane retention properties to AQP2 (Fenton et al., 2008; Hoffert et al., 2008; Moeller et al., 2009).

\section{PROTEINS CONTROLLING AQP2 TRAFFICKING}

Several proteins participating in the control of the localization and functioning of AQP2 at various levels have been identified (Table 2). They include, for example, proteins directing 
TABLE 1 | Renal aquaporins.

\begin{tabular}{|c|c|c|c|c|c|c|c|c|c|}
\hline Name & Class & Exons & Synonyms & $\begin{array}{l}\text { Kidney } \\
\text { segment }\end{array}$ & $\begin{array}{l}\text { Extrarenal } \\
\text { localization }\end{array}$ & $\begin{array}{l}\text { Subcellular } \\
\text { distribution }\end{array}$ & Function & KO mice show & References \\
\hline AQP1 & 1 & 4 & $\begin{array}{l}\text { AQP-CHIP, } \\
\text { CHIP28 }\end{array}$ & PT, DL & $\begin{array}{l}\text { Brain, } \\
\text { erythrocytes, } \\
\text { eye, heart, lung, } \\
\text { pancreas, } \\
\text { skeletal muscle, } \\
\text { vagina }\end{array}$ & $\begin{array}{l}\text { Apical and } \\
\text { basolateral } \\
\text { PM }\end{array}$ & $\begin{array}{l}\text { Constitutive water } \\
\text { reabsorption from } \\
\text { pre-urine, tubular } \\
\text { cell migration, } \\
\text { angiogenesis }\end{array}$ & $\begin{array}{l}\text { Impaired pain } \\
\text { sensation, polyuria }\end{array}$ & $\begin{array}{l}\text { Preston and Agre, 1991; Ma } \\
\text { et al., 1998; Bai et al., 1999; } \\
\text { Pallone et al., 2000; Vacca et al., } \\
\text { 2001; Saadoun et al., 2005; } \\
\text { Hara-Chikuma and Verkman, } \\
\text { 2006; Wang et al., 2008; Kim } \\
\text { et al., 2011b; Arrighi and Aralla, } \\
2014\end{array}$ \\
\hline AQP2 & 1 & 4 & $\begin{array}{l}\text { AQP-CD, } \\
\text { WCH-CD }\end{array}$ & CD-PC & $\begin{array}{l}\text { Ear, epididymis, } \\
\text { vagina }\end{array}$ & $\begin{array}{l}\text { Intracellular } \\
\text { vesicles, } \\
\text { apical and } \\
\text { basolateral } \\
\text { PM }\end{array}$ & $\begin{array}{l}\text { AVP-stimulated } \\
\text { water } \\
\text { reabsorption from } \\
\text { urine }\end{array}$ & $\begin{array}{l}\text { Fail to thrive, } \\
\text { polyuria }\end{array}$ & $\begin{array}{l}\text { Fushimi et al., 1993; Nielsen and } \\
\text { Agre, 1995; Nelson et al., 1998; } \\
\text { Merves et al., 2000; Rojek et al., } \\
\text { 2006; Kim et al., 2011b; Arrighi } \\
\text { and Aralla, } 2014\end{array}$ \\
\hline AQP4 & 1 & 4 & $\begin{array}{l}\text { MIWC, } \\
\text { WCH4 }\end{array}$ & $C D-P C$ & $\begin{array}{l}\text { Brain, eye, lung, } \\
\text { muscle, retinal } \\
\text { glia, skin, } \\
\text { stomach }\end{array}$ & $\begin{array}{l}\text { Basolateral } \\
\text { PM }\end{array}$ & $\begin{array}{l}\text { Water exit of } \\
\text { kidney CD-PC, } \\
\text { regulation of } \\
\text { water flow in } \\
\text { central nervous } \\
\text { system }\end{array}$ & $\begin{array}{l}\text { Impaired vision, } \\
\text { hearing, olfaction; } \\
\text { urinary } \\
\text { concentration } \\
\text { defects }\end{array}$ & $\begin{array}{l}\text { Hasegawa et al., 1994; Ma et al., } \\
\text { 1994, 1997; Yang et al., 1997; } \\
\text { Manley et al., 2000; Li and } \\
\text { Verkman, 2001; Zelenina et al., } \\
\text { 2002; Hiroaki et al., 2006; Ho } \\
\text { et al., } 2009\end{array}$ \\
\hline AQP5 & I & 4 & - & $\begin{array}{l}\text { CNT, } \\
\text { CD- } \beta I C\end{array}$ & $\begin{array}{l}\text { Ear, eye, lung, } \\
\text { salivary glands, } \\
\text { placenta, } \\
\text { pancreas, } \\
\text { vagina }\end{array}$ & Apical PM & $\begin{array}{l}\text { Generation of } \\
\text { saliva, tears and } \\
\text { pulmonary } \\
\text { secretion, } \\
\text { unknown renal } \\
\text { function }\end{array}$ & $\begin{array}{l}\text { Impaired salivary } \\
\text { and sweat } \\
\text { secretion, } \\
\text { decreased } \\
\text { osmotic water } \\
\text { permeability } \\
\text { across alveolar } \\
\text { epithelium }\end{array}$ & $\begin{array}{l}\text { Raina et al., 1995; He et al., } \\
\text { 1997; Ishida et al., 1997; Ma } \\
\text { et al., 1999; Mhatre et al., 1999; } \\
\text { Ma et al., 2000; Krane et al., } \\
\text { 2001a,b; Song and Verkman, } \\
\text { 2001; Nejsum et al., 2002; Kim } \\
\text { et al., 2011b; Procino et al., } \\
\text { 2011b; Wu et al., } 2013\end{array}$ \\
\hline AQP7 & $\|$ & 6 & AQPap & PT & $\begin{array}{l}\text { Adipose tissue, } \\
\text { brain, heart, } \\
\text { intestine, } \\
\text { skeletal muscle, } \\
\text { testis }\end{array}$ & Apical PM & $\begin{array}{l}\text { Glycerol } \\
\text { metabolism, } \\
\text { arsenite uptake }\end{array}$ & $\begin{array}{l}\text { Glyceroluria, } \\
\text { obesity, smaller } \\
\text { islet cells }\end{array}$ & $\begin{array}{l}\text { Ishibashi et al., 1997a, 2000a; } \\
\text { Kishida et al., 2000; Nejsum } \\
\text { et al., 2000; Liu et al., 2002; } \\
\text { Hara-Chikuma et al., 2005; } \\
\text { Hibuse et al., 2005; Sohara } \\
\text { et al., 2005, 2006a; Laforenza } \\
\text { et al., } 2013\end{array}$ \\
\hline AQP8 & 1 & 6 & - & PT & $\begin{array}{l}\text { Brain, } \\
\text { pancreas, } \\
\text { placenta, } \\
\text { salivary glands, } \\
\text { sperm, testis }\end{array}$ & $\begin{array}{l}\text { Intracellular } \\
\text { vesicles, PM }\end{array}$ & $\begin{array}{l}\text { Urea, amonia and } \\
\text { ROS transport }\end{array}$ & $\begin{array}{l}\text { Mild } \\
\text { hypertriglyceridemia }\end{array}$ & $\begin{array}{l}\text { Ishibashi et al., 1997b; Elkjaer } \\
\text { et al., 2001; Yang et al., 2005; } \\
\text { Bienert et al., 2007; Saparov } \\
\text { et al., 2007; Kobayashi and } \\
\text { Yasui, 2010; Tamma et al., } \\
\text { 2011b }\end{array}$ \\
\hline
\end{tabular}


TABLE 1 | Continued

\begin{tabular}{|c|c|c|c|c|c|c|c|c|c|}
\hline Name & Class & Exons & Synonyms & $\begin{array}{l}\text { Kidney } \\
\text { segment }\end{array}$ & $\begin{array}{l}\text { Extrarenal } \\
\text { localization }\end{array}$ & $\begin{array}{l}\text { Subcellular } \\
\text { distribution }\end{array}$ & Function & KO mice show & References \\
\hline AQP11 & III & 3 & AQPX1 & PT & $\begin{array}{l}\text { Brain, intestine, } \\
\text { liver, testis, } \\
\text { thymus }\end{array}$ & ER & $\begin{array}{l}\text { ER homeostasis, } \\
\text { spermiogenesis, } \\
\text { salivary gland } \\
\text { development }\end{array}$ & $\begin{array}{l}\text { Polycystic kidney } \\
\text { disease }\end{array}$ & $\begin{array}{l}\text { Ishibashi et al., 2000b; Morishita } \\
\text { et al., 2004, 2005b; Gorelick } \\
\text { et al., 2006; Ishibashi, 2006; } \\
\text { Yakata et al., 2007; Larsen et al., } \\
\text { 2010; Yeung and Cooper, } 2010\end{array}$ \\
\hline
\end{tabular}

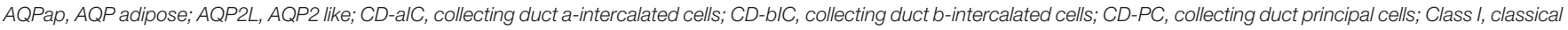

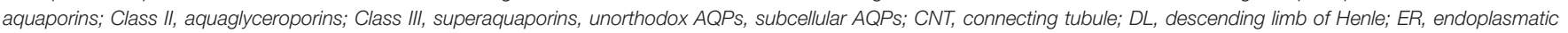

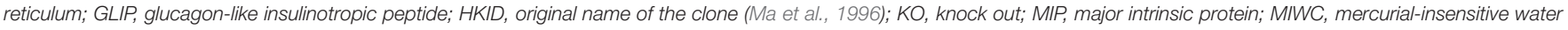
channel; PM, plasma membrane; PT, proximal tubule; SSC1, small solute channel 1; WCH4, water channel 4.

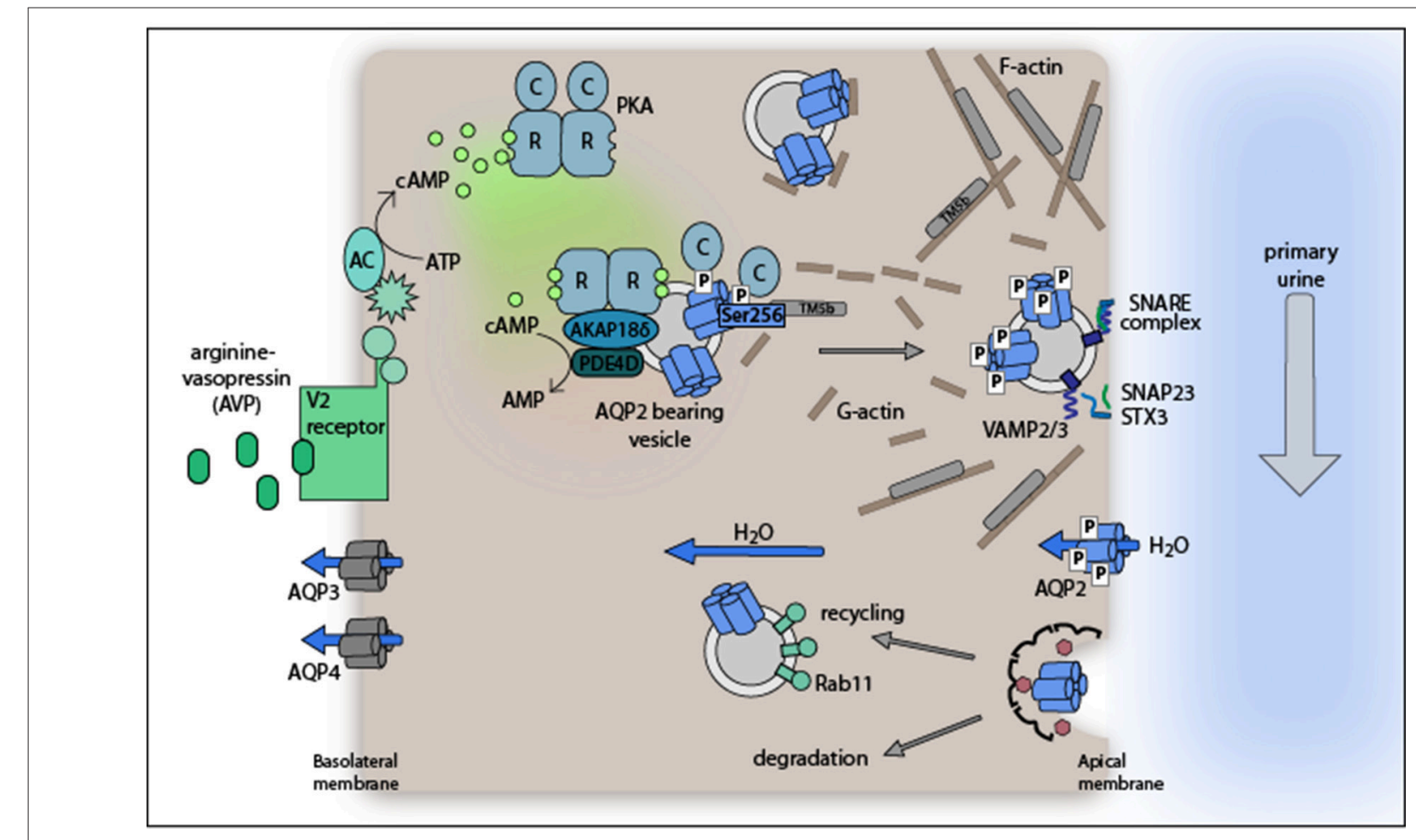

FIGURE 1 | Model of the arginine-vasopressin (AVP)-stimulated AQP2 translocation from intracellular vesicles into the plasma membrane of renal collecting duct principal cells. The plasma membrane insertion of AQP2 facilitates water reabsorption from hypoosmotic primary urine. The exocytosis-like process requires PKA phosphorylation of AQP2 at S256. Water exits the cells through water channels AQP3 and 4 constitutively expressed in the basolateral plasma membrane. For details please refer to section Proteins controlling AQP2 trafficking.

exo- and endocytic trafficking, cytoskeletal proteins as the tracks for the trafficking, proteins controlling cAMP signaling such as A-kinase anchoring proteins (AKAPs) and phosphodiestereases (PDEs). A few examples are discussed below.

\section{AKAPs}

AKAPs are scaffolding proteins. They tether PKA in close proximity of its substrates (Skroblin et al., 2010; Langeberg and Scott, 2015). Global inhibition of AKAP-PKA interactions in a cell culture model of renal principal cells, primary inner medullary collecting duct (IMCD) cells, revealed that AKAP-PKA interactions are crucial for the AVP-stimulated translocation of AQP2 (Klussmann et al., 1999; Klussmann and Rosenthal, 2001). AKAP18 $\delta$ and AKAP220 are located on AQP2bearing vesicles to tether PKA in close proximity of AQP2. They apparently facilitate the phosphorylation of S256 (Henn et al., 2004; McSorley et al., 2006; Okutsu et al., 2008).

\section{PDEs}

Termination of cAMP signaling is achieved through hydrolysis of cAMP by PDEs. There are 11 families of PDEs hydrolyzing cAMP, cGMP, or both. PDE4 family isozymes are cAMPspecific, constitutively active and shape local cAMP gradients, thus regulating its availability for PKA activation (Houslay, 2010; Klussmann, 2015; Mika and Conti, 2015). PDE4D directly 
TABLE 2 | Proteins controlling AQP2 expression and/or localization.

\begin{tabular}{|c|c|c|}
\hline Protein & Suggested functional implication & References \\
\hline Actin & Actin-depolymerization promotes AQP2 trafficking to the plasma membrane & $\begin{array}{l}\text { Simon et al., 1993; Umenishi et al., 2000; } \\
\text { Klussmann et al., 2001; Tamma et al., } \\
\text { 2001; Noda et al., 2004b, 2005, } 2008\end{array}$ \\
\hline AKAP18 & AKAP18 tethers PKA to AQP2-bearing vesicles, most likely facilitating its PKA phosphorylation & Henn et al., 2004 \\
\hline AKAP220 & AKAP220 tethers PKA to AQP2-bearing vesicles, most likely facilitating its PKA phosphorylation & Okutsu et al., 2008 \\
\hline Annexin & $\begin{array}{l}\text { Annexin II is required for AQP2 trafficking to and/or fusion with the plasma membrane; annexins II } \\
\text { and VI belong to a motor complex binding to AQP2; annexins I, II, IV, and V are located on } \\
\text { AQP2-bearing vesicles }\end{array}$ & $\begin{array}{l}\text { Barile et al., 2005; Noda et al., 2005; } \\
\text { Tamma et al., 2008; Zwang et al., } 2009\end{array}$ \\
\hline AP1/2 & AP1/2 mediates clathrin-mediated endocytosis of AQP2 & $\begin{array}{l}\text { Barile et al., 2005; Bouley et al., 2006; Lu } \\
\text { et al., } 2007\end{array}$ \\
\hline AP-1 & AP-1 increases AQP2 transcription & Yasui et al., 1997; Irarrazabal et al., 2008 \\
\hline $\mathrm{BIP}$ & $\begin{array}{l}\text { BiP selectively binds to phosphorylated AQP2; its functional implication regarding AQP2 is currently } \\
\text { unknown }\end{array}$ & Zwang et al., 2009; Cai et al., 2010 \\
\hline
\end{tabular}

\begin{tabular}{|c|c|c|}
\hline Calcineurin & $\begin{array}{l}\text { Calcineurin enhances AQP2 transcription and dephosphorylates AQP2 during GOLGI/vesicle } \\
\text { routing, allowing normal trafficking }\end{array}$ & $\begin{array}{l}\text { Valenti et al., 2000; Jo et al., 2001; Gooch, } \\
\text { 2006; Li et al., 2007; Rinschen et al., } 2011\end{array}$ \\
\hline Calcitonin & Calcitonin induces cAMP-dependent AQP2 trafficking to the plasma membrane & Bouley et al., 2011 \\
\hline Caveolin & Caveolin-1 was suggested to mediate AQP2 internalization & Aoki et al., 2012 \\
\hline CDK & CDK1 and CDK5 were shown to phosphorylate AQP2 at S261 & Rinschen et al., 2010 \\
\hline Clathrin & Clathrin forms coated pits for AQP2 endocytosis & $\begin{array}{l}\text { Strange et al., 1988; Verkman et al., 1988; } \\
\text { Katsura et al., 1995; Sun et al., } 2002\end{array}$ \\
\hline
\end{tabular}
COXII $\quad$ COXI is involved in renal prostanoid synthesis and its inhibition leads to enhanced AQP2 protein
abundance

CREB

CREB and CREB-like transcription factors increase AQP2 transcription

\begin{tabular}{|c|c|c|}
\hline CSNK & CSNK phosphorylates S256 during GOLGI transition of AQP2 & Brunati et al., 2000; Procino et al., 2003 \\
\hline Dynactin & Dynactin is located on AQP2-bearing vesicles and probably links them to the dynein complex & Marples et al., 1998 \\
\hline Dynamin & $\begin{array}{l}\text { Dynamin binds to AQP2 and is involved in the scission of clathrin-coated AQP2-bearing vesicles } \\
\text { during endocytosis }\end{array}$ & $\begin{array}{l}\text { Sun et al., 2002; Lu et al., 2004, 2007; } \\
\text { Barile et al., 2005; Moeller et al., } 2010\end{array}$ \\
\hline Dynein & Dynein mediates the microtubule-associated transport of endocytotic AQP2-bearing vesicles & $\begin{array}{l}\text { Marples et al., 1998; Vossenkämper et al., } \\
2007\end{array}$ \\
\hline EPAC & Epac triggers AQP2 translocation to the plasma membrane $\mathrm{Ca}^{2+}$-dependently & $\begin{array}{l}\text { Umenishi et al., 2006; Yip, 2006; } \\
\text { Kortenoeven et al., 2012b }\end{array}$ \\
\hline ERK & $\begin{array}{l}\text { ERK1/2 increases AQP2 transcription via the cAMP/Epac/ERK/CREB pathway; ERK1/2 may } \\
\text { mediate S256 phosphorylation under hypertonic conditions; ERK1/2 phosphorylates S261 in vitro }\end{array}$ & $\begin{array}{l}\text { Bustamante et al., 2005; Hoffert et al., } \\
\text { 2006; Umenishi et al., 2006; Nielsen et al., } \\
\text { 2008a; Hasler et al., 2008b; Rinschen } \\
\text { et al., } 2010\end{array}$ \\
\hline GSK3 $\beta$ & $\begin{array}{l}\text { GSK3 } \beta \text { enhances PGE2 production by stimulation of COXII, which causes endocytic retrieval of } \\
\text { AQP2; GSK3 } \beta \text { inhibition was suggested to reduce AVP-induced AC activity }\end{array}$ & $\begin{array}{l}\text { Rao et al., 2005, 2010; Brown et al., } \\
\text { 2008; Nielsen et al., 2008b }\end{array}$ \\
\hline $\begin{array}{l}\text { HSC70, } \\
\text { HSP70 }\end{array}$ & $\begin{array}{l}\text { Hsc70 and Hsp70 are involved in clathrin-mediated endocytosis of AQP2, were shown to bind } \\
\text { AQP2 and suggested to affect AQP2 trafficking to the plasma membrane }\end{array}$ & $\begin{array}{l}\text { Lu et al., 2007; Zwang et al., 2009; } \\
\text { Moeller et al., 2010; Rice et al., 2012; Park } \\
\text { et al., } 2013\end{array}$ \\
\hline
\end{tabular}

Nørregaard et al., 2005, 2010, 2011; Jensen et al., 2006, 2010; Kim et al., 2008; Kortenoeven et al., 2011

Hozawa et al., 1996; Matsumura et al., 1997; Yasui et al., 1997; Umenishi et al., 2006; Yu et al., 2009

Brunati et al., 2000; Procino et al., 2003

(Continued) 


\section{TABLE 2 | Continued}

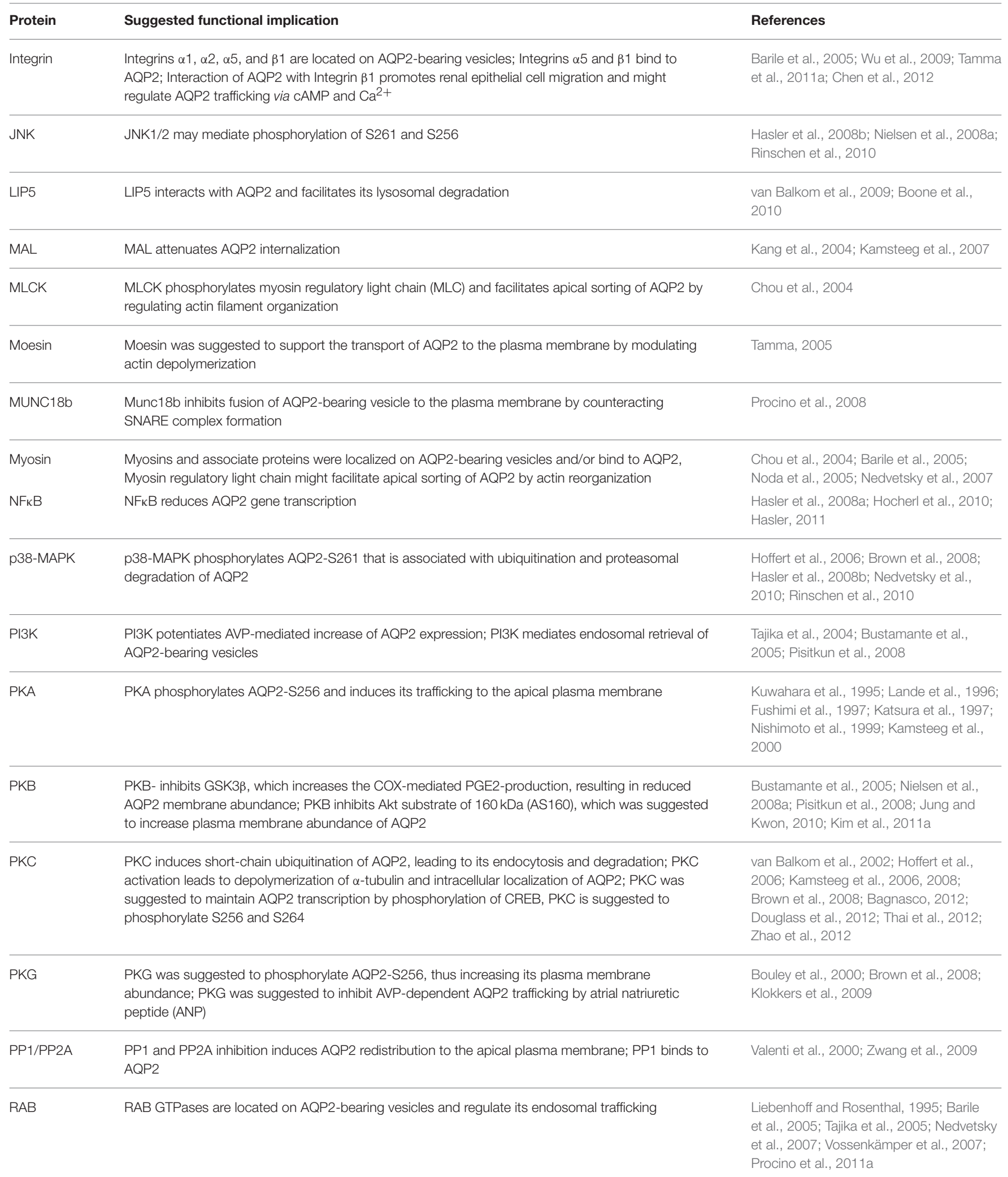




\section{TABLE 2 | Continued}

\begin{tabular}{|c|c|c|}
\hline Protein & Suggested functional implication & References \\
\hline RAN & RAN binds to AQP2 but its significance regarding AQP2 control is not known & Zwang et al., 2009 \\
\hline SNAP & $\begin{array}{l}\text { SNAP23 and SNAP25 are located on AQP2-bearing vesicles and participate in SNARE complex } \\
\text { formation during vesicle and plasma membrane fusion }\end{array}$ & Inoue et al., 1998; Shukla et al., 2001 \\
\hline SPA-1 & SPA-1 binds to AQP2 and stimulates AQP2 trafficking to the apical plasma membrane & Noda et al., 2004a \\
\hline Synaptotagmin & $\begin{array}{l}\text { Synaptotagmin-13 is located on AQP2-bearing vesicles and might be involved in SNARE complex } \\
\text { formation during vesicle and plasma membrane formation }\end{array}$ & Kishore et al., 1998; Barile et al., 2005 \\
\hline Syntaxin & $\begin{array}{l}\text { Syntaxins are involved in SNARE complex formation during fusion of AQP2 vesicle and plasma } \\
\text { membrane; syntaxins } 1 \text { A, 2, } 3 \text { and } 4 \text { are located in the plasma membrane of kidney epithelial cells, } \\
\text { syntaxins } 5 A, 7,12,13 \text { and } 16 \text { are located on AQP2-bearing vesicles }\end{array}$ & $\begin{array}{l}\text { Mandon et al., 1996, 1997; Gouraud, } \\
\text { 2002; Brooks et al., 2003; Barile et al., } \\
\text { 2005; Procino et al., 2008; Mistry et al., } \\
2009\end{array}$ \\
\hline TONEBP & TonEBP increases AQP2 transcription during hypertonic stress response & $\begin{array}{l}\text { Storm et al., 2003; Lam et al., 2004; } \\
\text { López-Rodríguez et al., 2004; Hasler } \\
\text { et al., 2006; Li et al., 2007; Hasler, } 2011\end{array}$ \\
\hline TRPC3 & $\begin{array}{l}\text { TRPC3 interacts and translocates with AQP2 upon AVP stimulation, its functional implication is } \\
\text { presently unknown }\end{array}$ & Goel et al., 2007, 2010 \\
\hline TRPV4 & TRPV4 interacts with AQP2, the functional implication is presently unknown & Galizia et al., 2012 \\
\hline Tubulin & $\begin{array}{l}\alpha \text { - and } \beta \text {-tubulin are located on AQP2-bearing vesicles; tubulin forms microtubules, which } \\
\text { participate in AVP-elicited apical sorting of AQP2-bearing vesicles and perinuclear positioning of } \\
\text { AQP2 after endocytosis }\end{array}$ & $\begin{array}{l}\text { Sabolic et al., 1995; Breton and Brown, } \\
\text { 1998; Marples et al., 1998; Shaw and } \\
\text { Marples, 2002; Kang et al., 2004; Barile } \\
\text { et al., 2005; Tajika et al., 2005; } \\
\text { Vossenkämper et al., 2007; Zhao et al., } \\
\text { 2012; Yui et al., } 2013\end{array}$ \\
\hline VACM-1 & VACM-1 targets E3 ligase formation and decreases AQP2 protein abundance & Lee et al., 2011; Le et al., 2012 \\
\hline VAMP & $\begin{array}{l}\text { VAMP2 and } 3 \text { are located both on AQP2-bearing vesicles and in the plasma membrane and are } \\
\text { involved in SNARE complex formation during vesicle and plasma membrane fusion; VAMP8 was } \\
\text { suggested to be located on AQP2-bearing vesicles and to be implicated in SNARE complex } \\
\text { formation }\end{array}$ & $\begin{array}{l}\text { Franki et al., 1995; Jo et al., 1995; } \\
\text { Liebenhoff and Rosenthal, 1995; Marples } \\
\text { et al., 1995; Nielsen et al., 1995; } \\
\text { Inoue et al., 1998; Gouraud, 2002; Barile } \\
\text { et al., 2005; Procino et al., 2008; Wang } \\
\text { et al., } 2010\end{array}$ \\
\hline
\end{tabular}

Several proteins were shown to regulate AQP2 expression, abundance, subcellular localization, and degradation. Listed proteins act downstream of receptor activation. For most of them indirect evidence supports their role in AQP2-mediated water reabsorption. AKAP, A-kinase anchor protein, AKAP188/AKAP78, AKAP220/AKAP11; AP1/2, adaptor protein; AP-1, activator protein; BIP/GRP78/HSP50-5/HSPA5/HSP70-5, Heat shock $70 \mathrm{kDa}$ protein 5/Immunoglobulin heavy chain-binding protein/78 kDa g/ucose-regulated protein precursor; Calcineurin, Protein phosphatase 2B, PP2B; CSNK, Golgi casein kinase, casein kinase; CDK, Cyclin-dependent kinase; COX, Cyclooxygenase-2; CREB, Cyclic AMP responsive element binding protein; EPAC, Exchange protein activated by CAMP; ERK, Extracellular signal-regulated kinase, ERK1/MAPK3, ERK2/MAPK1; GSK3B, Glycogen synthase kinase 3B; HSC, Heat shock cognate; HSP, Heat shock protein; JNK, c-Jun NH2-terminal kinase; LIP5, Lysosomal trafficking regulator interacting protein-5; MAL, Myelin and lymphozyte associated protein, JNK1/MAPK8, JNK2/MAPK9; MAPK, mitogen activated protein kinase; MLCK, Myosin light chain kinase; Moesin, part of ERM (ezrin/radixin/moesin) protein compex; Munc18b, Unc18-2, Syntaxin-binding protein 2; NFKB, Nuclear factor "kappa-light-chain-enhancer" of activated B-cells; P38-MAPK, p38 mitogen activated protein kinase, MAPK14; PI3K, Phosphoinositide-3-kinase, MAPK14; PKA/B/C/G, Protein kinase A/B/C/G; PP1, Serine/threonine-proteine phosphatase 1; PKB/AKT; RAB, Ras-related protein; RAN, Ras-related nuclear protein; RHOA, Ras homolog family member A; SNAP, Synaptosomal-associated protein 25; SPA-1, Signal-induced proliferation-associated protein 1; TM5b, $\alpha$-Tropomyosin 5b; TONEBP, tonicity-responsive enhancer binding protein/NFAT5, Nuclear factor of activated T-cells 5/OREBP, Osmotic respone element binding protein; TRPC3, Transient receptor potential cation channel subfamily C member 3; TRPV4, Transient receptor potential cation channel subfamily V member 4; VACM, Vasopressin-activated calcium mobilizing, Cullin 5; VAMP2, Vesicle associated membrane protein/Synaptobrevin; VAMP3, Vesicle associated membrane protein/Cellubrevin. 
interacts with AKAP18 $\delta$ on AQP2-bearing vesicles (Stefan et al., 2007). The presence of PDE4D on AQP2-bearing vesicles prevents an inappropriate plasma membrane insertion of AQP2 and thus water reabsorption in resting IMCD cells. Specific PDE4 inhibition with rolipram did not induce, but enhance the cAMPstimulated AQP2 translocation into the plasma membrane (Stefan et al., 2007; Szaszák et al., 2008). On the other hand, hyperactive PDE4 diminishes intracellular cAMP and causes AVP resistance in a mouse model (Valtin et al., 1990; Takeda et al., 1991).

\section{Cytoskeletal Components}

AQP2 is folded and assembled into homotetramers in the endoplasmic reticulum (ER), passes through the Golgi and is then stored in intracellular vesicles in the perinuclear region. Under resting conditions, AQP2 binds monomeric G-actin (Noda et al., 2004b, 2008). PKA-mediated AQP2 phosphorylation of S256 weakens the interaction. This increases the affinity of AQP2 to the actin-stabilizing protein tropomyosin-5b, withdrawing it from F-actin. Consequently, actin depolymerizes, enabling the vesicle redistribution to the plasma membrane (Noda et al., 2008). AVPstimulated AQP2 vesicle trafficking to the plasma membrane depends on F-actin depolymerization (Simon et al., 1993). Activation of the small GTPase RhoA induces F-actin-containing stress fibers and tonically inhibits AQP2 trafficking (Klussmann et al., 2001; Tamma et al., 2001). Activated PKA phosphorylates and thereby inhibits RhoA (Lang et al., 1996; Dong et al., 1998), contributing to the AVP-induced destabilization of the actin network. A role of actin in the redistribution of AQP2 is supported by observations in cultured renal collecting duct cells (CD8 cells) treated with the serine/threonine phosphatase 1 and $2 \mathrm{a}$ inhibitor, okadaic acid. The agent increased the AQP2 phosphorylation of AQP2 at S256 by around $60 \%$ and led to a depolymerization of the actin network. These findings also supported the notion that the redistribution of AQP2 is not exclusively controlled by PKA (Valenti et al., 2000).

\section{SNAREs}

The plasma membrane insertion of AQP2 occurs in an exocytosis-like manner involving the SNARE (soluble $\mathrm{N}$ ethylmaleimide sensitive factor attachment protein receptor) machinery (Liebenhoff and Rosenthal, 1995; Gouraud, 2002). The vesicle-associated membrane proteins (VAMP) 2 and 3 reside on AQP2-bearing vesicles. They interact with apical plasma membrane-located syntaxin 3 and the synaptosomeassociated protein (SNAP) 23 to achieve vesicle fusion and the insertion of AQP2 into plasma membrane (Barile et al., 2005; Procino et al., 2008).

\section{Proteins for AQP2 Endocytosis and Recycling}

Adjustment of body water balance by AQP2-mediated water reabsorption leads to a decline of AVP, followed by internalization of AQP2. AQP2 retrieval from the plasma membrane proceeds via clathrin-mediated endocytosis (Sun et al., 2002). AVP stimulates co-accumulation of Hsc70 and AQP2 in the apical plasma membrane (rat kidney sections), and functional Hsc70 is required for AQP2 endocytosis in LLC-PK cells stably expressing AQP2. AQP2 directly interacts with the endocytotic proteins clathrin, dynamin, and the adaptor protein AP2 (Lu et al., 2007). The phosphomimic mutants S256D and S269D of AQP2 show reduced interactions with the endocytotic machinery, which reduces internalization and increases half-life due to decreased proteasomal degradation (Moeller et al., 2010).

Myelin and lymphocyte-associated protein (MAL), a protein found in glycosphingolipid-enriched membranes and potentially involved in the apical transport machinery forms a complex with AQP2 in LLC-PK 1 cells (Frank et al., 1998; Martín-Belmonte et al., 2000; Kamsteeg et al., 2007). As phosphorylation of S256 strengthens the interaction with MAL and MAL attenuates AQP2 internalization, this is in line with the above-described reduced endocytosis to explain the stabilization and accumulation of pS256 in the apical plasma membrane.

From the plasma membrane AQP2 is recycled or directed for degradation. The motor protein myosin $\mathrm{Vb}$, its receptor on AQP2-bearing vesicles, Rab11, and the adaptor protein Rab11FIP2 are essential for recycling through the Rab11-dependent recycling pathway (Nedvetsky et al., 2007). Positioning of AQP2bearing vesicles in their perinuclear storage region involves microtubules (Vossenkämper et al., 2007).

\section{Ubiquitin}

Under resting conditions AQP2 is phosphorylated at S261 by, amongst others p38 MAP kinase (Nedvetsky et al., 2010). The phosphorylation is a signal for AQP2's mono- and poly-ubiquitination. The short-chain ubiquitination of AQP2 at K270 increases its endocytosis under resting conditions (Kamsteeg et al., 2006). In primary IMCD cells, AVP causes a decrease in the phosphorylation of S261 within $30 \mathrm{~min}$ of exposure. This reduces polyubiquitination and prevents AQP2's proteasomal degradation resulting in an increase in its abundance. Thus, AQP2 expression adapts quickly to water availability: thirsting increases, whereas water overload reduces AQP2 levels (Nedvetsky et al., 2010). The AVP-induced reduction of polyubiquitination of AQP2 implies that its recycling via the Rab11 pathway requires its deubiquitination.

AQP2 short-chain ubiquitination and subsequent internalization can occur independently of the AVP-PKA axis upon activation of protein kinase C (PKC) (Han et al., 1994; van Balkom et al., 2002; Kamsteeg et al., 2006). Prostaglandin $2\left(\mathrm{PGE}_{2}\right)$ or dopamine counteract AVP and induce AQP2 retrieval from the apical plasma membrane (Zelenina et al., 2000; Edwards and Brooks, 2001). The underlying pathway is not fully elucidated. In addition to PKC it may involve modulation of the ubiquitination of AQP2 (Hébert et al., 1990; Tamma et al., 2003b; Nejsum et al., 2005).

\section{DYSREGULATION OF AVP-MEDIATED WATER REABSORPTION CAUSES WATER BALANCE DISORDERS}

Several diseases are associated or caused by dysregulation of AVP-mediated water reabsorption (Figure 2). Elevated levels of 


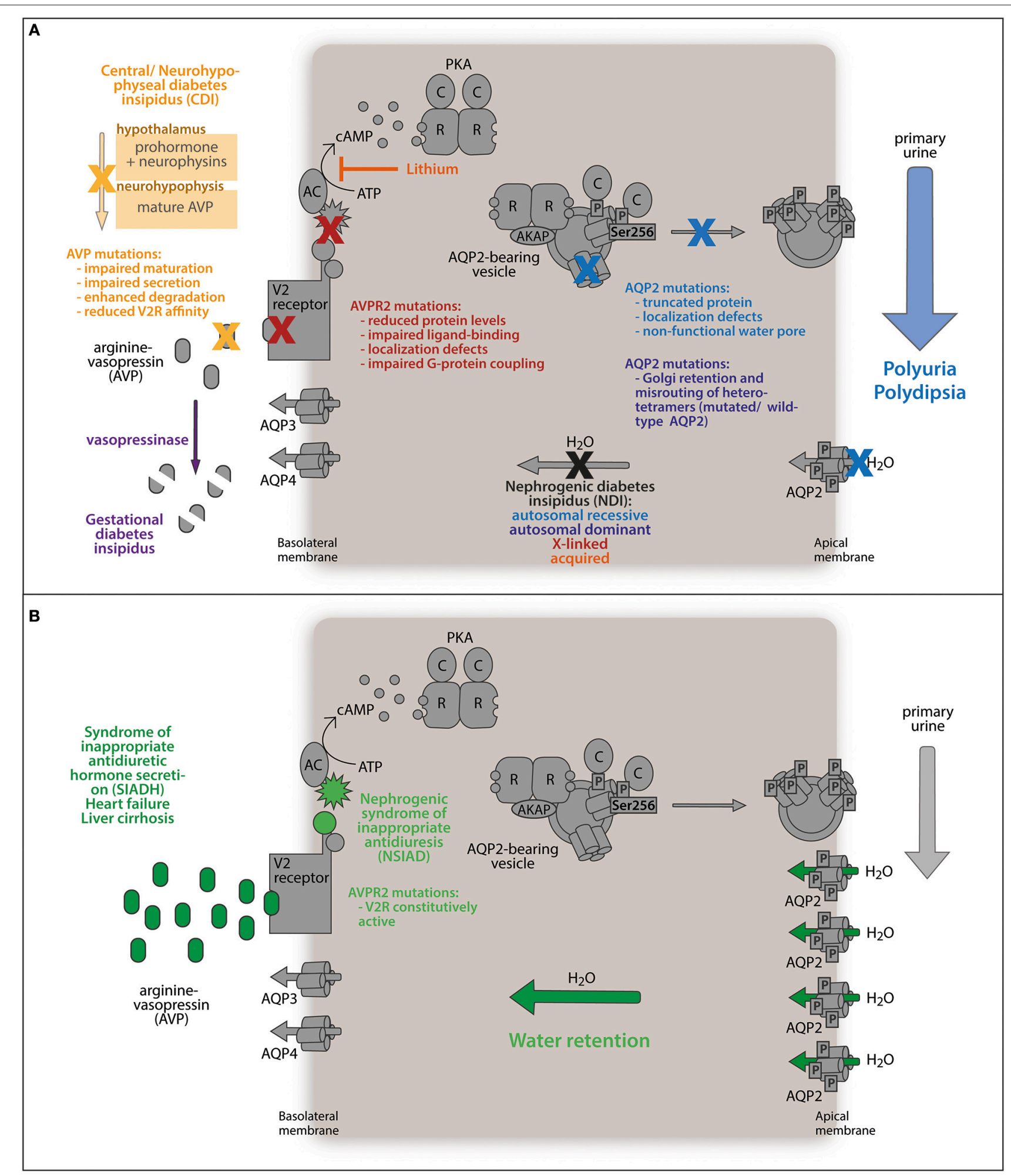

FIGURE 2 | Water balance disorders. (A) Diabetes insipidus describes the abnormal loss of hypoosmotic urine (polyuria) along with increased thirst (polydipsia). The antidiuretic peptide hormone arginine-vasopressin (AVP) is synthesized in the hypothalamus as a prohormone. Mature AVP is secreted from the neurohypophysis to stimulate the kidneys to retain water. Mutations in the AVP gene impede correct processing or reduce its affinity for the V2 receptor, which precludes AVP-mediated water reabsorption from primary urine and is termed central diabetes insipidus (CDI). In the rare case of gestational diabetes insipidus, placenta-released vasopressinase degrades AVP, counteracting antidiuretic signaling. Similarly, mutations in the gene encoding the V2 receptor (AVPR2) render renal principal cells

(Continued) 
FIGURE 2 | Continued

AVP-resistant. Defects in AQP2 protein expression, channel function, intracellular sorting, or membrane translocation disrupt the responsiveness of principal cells to antidiuretic stimuli and maintains low water permeability of the kidney collecting duct. (B) Deregulated accumulation of AVP enhances antidiuretic stimulation of renal principal cells through the V2 receptor and triggers enhanced AQP2-conducted water reabsorption from the primary urine urine (SIADH, heart failure, liver cirrhosis). The same effect is caused by a mutation in the AVPR2 gene constitutively activating the receptor. Both defects abnormally elevate water retention.

$\mathrm{AVP}$ as in the syndrome of inappropriate antidiuretic hormone secretion (SIADH), late stage heart failure, and liver cirrhosis cause excessive water retention. Defects preventing the insertion of AQP2 into the plasma membrane lead to diabetes insipidus.

\section{DECREASED AVP-MEDIATED WATER REABSORPTION CAUSES DIABETES INSIPIDUS}

Patients suffering from diabetes insipidus display a limited ability to concentrate urine. This leads to polyuria and polydipsia (Knoers, 1993; Bockenhauer and Bichet, 2015), and if untreated to severe dehydration, hypernatremia, and hyperchloremia (Multari et al., 2001; Qureshi et al., 2014).

Diabetes insipidus may be inherited or acquired. In central diabetes insipidus (CDI) mutations in the gene encoding AVP lead to insufficient amounts of AVP released from the pituitary gland. The consequence is a compromised concentrating ability of the collecting duct due to a low level of V2R stimulation and abnormally low AQP2 levels, resulting from the lack of AVP-dependent AQP2 gene expression (Ishikawa, 2000). The prevalence of CDI is 1 in 25,000 (www.orpha.net). An animal model reproducing CDI is the Brattleboro rat. The rats lack AVP and the expression levels of AQP2 are decreased (Sokol and Zimmerman, 1982; Kishore et al., 1996).

Mutations in the V2R gene (X-chromosome, Xq28) cause Xlinked NDI, which accounts for $\sim 90 \%$ of all congenital NDI forms (Peters et al., 2007; Heinke and Labudde, 2012). Due to the lack of a functional V2R gene, the AQP2 level is decreased and $\mathrm{AQP} 2$ does not translocate into the plasma membrane. The prevalence of X-linked NDI is 3.7 in 1 million males (Bichet et al., 1992). Interestingly, in the Canadian province Nova Scotia the incidence is much higher with 58 in 1 million male live births, a founder effect discussed as the "Hopewell hypothesis" (Bichet et al., 1993; Arthus et al., 2000). The X-linked inheritance is obviously more apparent in males due to the lack of a second $\mathrm{X}$ chromosome. Even after administration of dDAVP (see below) the male patients do not show signs of improvement (Knoers and Deen, 2001). An animal model reproducing the phenotype is the inducible V2R knockout mouse model (Li et al., 2009a).

The remaining $\sim 10 \%$ of the persons with congenital autosomal recessive and autosomal dominant forms of NDI carry mutations in the AQP2 gene (Deen et al., 1994; Park et al., 2014). Autosomal dominant forms were observed in patients with frame shift mutations producing a C-terminally elongated AQP2 protein (721delG/727delG) or a mutation leading to an E258K substitution (Mulders et al., 1998; Kuwahara et al., 2001; Marr et al., 2002b). When overexpressed in Xenopus oocytes, the E258K, and AQP2-727delG versions were misrouted to the Golgi and late endosomes, respectively (Mulders et al., 1998; Marr et al., 2002b). The dominant-negative effect seems to be conferred by the formation of heterotetramers with wild type AQP2 that fail to translocate to the plasma membrane in response to AVP (Marr et al., 2002b). Disruption of the PKA consensus sequence by the substitution R254L interferes with the AVP-induced PKA phosphorylation of S256 and also leads to autosomal dominant NDI (de Mattia et al., 2005). The AQP2 version S256L, associated with congenital progressive hydronephrosis, cannot be phosphorylated and causes a severe urine concentration defect in mice, underpinning the importance of S256 for controlling water homeostasis (McDill et al., 2006).

Most of the more than 30 known AQP2 mutations associated with hereditary nephrogenic diabetes insipidus cause autosomal recessive NDI (Fujiwara and Bichet, 2005; Park et al., 2014; Cen et al., 2015). The mutations predominantly cause ER retention and impair protein stability and proper channel function (Deen et al., 1995; Mulders et al., 1997; Goji et al., 1998; Marr et al., 2002a). In comparison to the autosomal dominant mutants, the recessive ones such as AQP2-R187C do not form heterotetramers with wild type AQP2 (Kamsteeg et al., 1999).

There are several animal models available for studying AQP2 in the pathophysiology of NDI (Boone and Deen, 2009). Mice globally lacking AQP2 or mice expressing the T126M mutant die within 2 weeks of age (Yang et al., 2001; Rojek et al., 2006). The collecting duct-specific knockout of AQP2 enabled survival. In addition, mouse models with an amino acid substitution in the PKA phosphorylation site (S256A; McDill et al., 2006), an F204V substitution (Lloyd et al., 2005) or a complete deletion of the C-terminus were established to study recessive NDI (Shi et al., 2007). Sohara et al. presented the first mouse model for autosomal-dominant NDI, in which the assembly of mutant with wild type AQP2 into heterotetramers supported the in vitro findings (Sohara et al., 2006b). Using this model the PDE inhibitor rolipram was identified as a potential drug to treat autosomal-dominant NDI.

The most common form of NDI is acquired NDI. One of the main causes is the long-term treatment of bipolar disorders with lithium. This causes acquired NDI in up to $40 \%$ of the patients (Sim et al., 2014). In elderly patients a 6-year prevalence rate of 3\% was observed (Rej et al., 2014). The uptake route of lithium into collecting duct principal cells is through the epithelial sodium channel (ENaC). Lithium inhibits adenylyl cyclases and thereby cAMP synthesis and, consequently, the cAMP-dependent signaling that controls AQP2 trafficking and expression. A marked decrease in AQP2 expression in human and rat medullary collecting ducts has been reported with longterm lithium carbonate treatment (Blount et al., 2010).

Gestational DI is another form of acquired NDI. It manifests during pregnancy in the third trimester and in the early 
postpartum period. During pregnancy, the threshold level of serum osmolality to induce AVP secretion is lowered. The metabolic AVP clearance is increased due to increased levels of the trophoblast-produced aminopeptidase vasopressinase, which can lead to a transient form of DI (Barron et al., 1984; Durr et al., 1987; Davison et al., 1989). Gestational DI has a prevalence of 2-4 in 100,000 pregnancies and can be treated with dDAVP (see below), as this AVP analog is resistant to degradation by vasopressinase (Ananthakrishnan, 2009). Placental abruption can cause acute postpartum DI owing to high amounts of placental vasopressinase released into the circulation (Wallia et al., 2013). Occurrence of gestational DI is elevated in women with preeclampsia, HELLP syndrome (Hemolysis, Elevated Liver enzymes, and Low Platelets) or liver steatosis. These conditions present defective hepatic vasopressinase degradation (Katz and Bowes, 1987; Usta et al., 1994; Ellidokuz et al., 2006).

Bilateral ureteral obstruction (BUO) can cause acquired NDI with a marked decrease in AQP2 abundance (Jensen et al., 2009; Radin et al., 2012). In a rat model, the AQP2 level drops to a fourth of the control within $24 \mathrm{~h}$ upon induction of BUO and the phosphorylation of S256 is decreased (Stødkilde et al., 2011). Even 1 week after the release of BUO and when the urine output had become normal, AQP2 levels reached only half those of the controls. Upon dehydration, the affected rats were not able to efficiently concentrate urine (Frøkiaer et al., 1996), indicating that reduced levels of AQP2 are the main limiting factor during recovery from polyuria caused by BUO.

Acquired NDI can also be caused by hypercalcemia (Khairallah et al., 2007; Kamath et al., 2013), hypokalemia (Celik et al., 2014), and secondary hyperaldosteronism (Lee et al., 2010; Qureshi et al., 2014).

\section{INCREASED AVP-MEDIATED WATER REABSORPTION CAUSES WATER RETENTION AND HYPONATREMIA DISORDERS}

In SIADH, late stage heart failure, and liver cirrhosis elevated levels of AVP lead to diluted plasma with hyponatremia with or without hypervolemia. Hyponatremia is a physiological response to maintain an adequate circulating blood volume but turns into an electrolyte disorder when serum sodium drops to less than 135 $\mathrm{mEq} / \mathrm{L}$.

SIADH is the most frequent cause of hyponatremia, accounting for approximately one-third of all cases (Ishikawa, 2015). The abundance and plasma membrane localization of AQP2 is increased (Kortenoeven et al., 2013), which leads to excessive water retention and hypervolemic (dilutional) hyponatremia (Fenske and Allolio, 2010; Braun et al., 2015). A mutation in the V2R gene that causes nephrogenic syndrome of inappropriate antidiuresis (NSIAD) leads to constitutively active receptors triggering SIADH-like symptoms without elevated AVP levels (Feldman et al., 2005).

In humans with heart failure and in several animal models of heart failure, RAAS system activity, the non-osmotic release of AVP and the expression level and membrane localization of AQP2 are significantly increased. The consequence is water retention with increased circulatory blood volume (Radin et al., 2012; Cui et al., 2015; Ishikawa, 2015). An excessive circulatory volume results in hypervolemic hyponatremia. These patients have a poor prognosis (Noveanu et al., 2011). However, recent studies of heart failure in rat models revealed increased AQP2 protein abundance even in the presence of normal AVP and unchanged plasma sodium levels (Hadrup et al., 2004). Thus in heart failure AQP2 may be up-regulated more generally than previously thought (Brønd et al., 2013).

Liver cirrhosis is associated with a non-osmotic AVP release, water retention and hyponatremia (John and Thuluvath, 2015). The NO concentration in the plasma of cirrhosis patients correlates with the extent to which AQP2 levels are increased (Chung et al., 2010). However, the underlying mechanisms modulating water reabsorption through $\mathrm{AQP} 2$, and sodium excretion are unknown (Wilson et al., 2013).

Nephrotic syndrome is similar to heart failure and liver cirrhosis with regard to increased AVP levels and water retention (Apostol et al., 1997; Bou Matar et al., 2012). In contrast to heart failure and liver cirrhosis the nephrotic syndrome shows an "escape" from AVP in the renal collecting ducts. This "escape phenomena" is characterized by a notable down-regulation of AQP2 expression despite high AVP levels. Water balance disorders associated with "escape" phenomena are characterized by an ability to prevent water retention and hyponatremia via secondary natriuresis (Brønd et al., 2004; Verbalis, 2006). A possible mechanism involved in the AVP "escape" includes reduced V2 receptor binding and uncoupling of the V2 receptor from its cognate $\mathrm{G}$ protein resulting in abnormally low cytosolic cAMP concentrations upon dDAVP stimulation (Ecelbarger et al., 1998; Tian et al., 2000; Jonassen et al., 2003; Brønd et al., 2004).

\section{ESTABLISHED PHARMACOLOGICAL TREATMENTS OF DIABETES INSIPIDUS AND NEW OPTIONS}

\section{Desmopressin (dDAVP)}

CDI is commonly treated by the administration of an AVP analog, desmopressin (dDAVP), for example, via a nasal spray or infusion (van Balkom et al., 2004; Kortenoeven and Fenton, 2014). Chronic treatment with dDAVP increases the AQP2 level in apical plasma membranes of both cortical and inner medullary collecting duct principal cells, and decreases urine output usually drastically (Agarwal and Gupta, 2008; Kortenoeven and Fenton, 2014).

\section{Diuretics}

The main strategy for the treatment of X-linked NDI is to bypass non-functional V2R and restore physiological expression levels of AQP2 as well as AQP2 trafficking. Thiazides are widely used in patients with NDI. They decrease urine volume, but the mechanism by which they exhibit their paradoxical antidiuretic effect is poorly understood (Kim et al., 2004a). It was proposed that thiazides inhibit reabsorption of sodium and chloride in the 
distal collecting duct and thus increase the osmolality of the urine (Bockenhauer and Bichet, 2014).

Hydrochlorothiazide (HCTZ) combined with amiloride is the main therapy in patients with lithium-induced NDI (Sinke et al., 2014). Treatment with thiazides can decrease the glomerular filtration rate, which causes a reduced excretion of lithium, resulting in lithium intoxication. Amiloride, a potassium sparing diuretic, interferes with lithium uptake by blocking $\mathrm{ENaC}$, and for this reason is combined with thiazides (Bedford et al., 2008; Kishore et al., 2015). Also a combination of HCTZ with the NSAID, indomethacin (see below) reduces urine output more effectively than the administration of thiazides alone (Kortenoeven and Fenton, 2014). The expression of AQP2 was substantially reduced in the collecting ducts of lithium-treated rats and was increased in the presence of amiloride (Bedford et al., 2008).

\section{Statins}

Statins are lipid-lowering drugs used to reduce cardiovascular risks. They competitively inhibit hepatic 3-hydroxy-3methylglutaryl-coenzyme A reductase catalyzing the conversion of HMG-CoA to mevalonate. Thereby statins inhibit the production of isoprenoid intermediates such as farnesyl pyrophosphate (FPP), geranylgeranyl pyrophosphate (GGPP). A range of proteins undergoes post-translational modifications by addition of isoprenoid pyrophosphates (Verhulst et al., 2004). FPP and GGPP act as lipid anchors required for membrane tethering and activation of heterotrimeric $G$ proteins and small GTPases, amongst them RhoA (Li et al., 2011; Szygula-Jurkiewicz et al., 2014). Statins inhibit RhoA isoprenylation, leading to the accumulation of inactive RhoA in the cytoplasm (Liao and Laufs, 2005).

In MCD4 cells, mouse collecting duct cells stably expressing AQP2, statins inhibit the isoprenylation and thus activation of RhoA (Procino et al., 2010). This causes F-actin depolymerization and an AVP-independent increase in AQP2 plasma membrane localization (Bouley et al., 2008; Procino et al., 2010, 2011a; Li et al., 2011; Wade, 2011). Statins also activate the NO/cGMP pathway (Tamma et al., 2003a; Rikitake and Liao, 2005; Maher et al., 2009) and thus may induce AQP2 phosphorylation at S256 and thereby induce the insertion into the plasma membrane. Incubation of $\mathrm{LLC}^{-\mathrm{PK}_{1}}$ and MCD4 cells with simvastatin resulted in AQP2 plasma membrane accumulation in a dosedependent manner due to reduced clathrin-mediated endocytosis (Procino et al., 2012). Short-term exposure to simvastatin produced no change in cholesterol plasma membrane levels, but increased AQP2 accumulation in the apical membrane of principal cells in Brattleboro rats. This increased water reabsorption and urine concentration ( $\mathrm{Li}$ et al., 2011; Bonfrate et al., 2015). In adult Munich-Wistar male rats subjected to BUO for $2 \mathrm{~h}$ atorvastatin improved urinary concentrating ability by reversing ureteral obstruction-induced down-regulation of AQP2 (Danilovic et al., 2012). Fluvastatin increased AQP2 plasma membrane abundance in wild-type mice. In the same study when X-linked NDI mice were treated with secretin plus fluvastatin, urine volume was reduced by nearly $90 \%$ and the urine osmolality was doubled. Fluvastatin promoted AQP2 trafficking to the plasma membrane whereas secretin increased intracellular stores of AQP2 (Procino et al., 2014). Additional experiments in mice indicated that fluvastatin increases AQP2 membrane accumulation by altering the prenylation status of key proteins regulating AQP2 trafficking such as RhoA (Procino et al., 2011a).

In a recent study, 24 naïve hypercholesterolemic patients were treated with simvastatin $(20 \mathrm{mg}$ /day for 12 weeks). This rapidly and significantly enhanced urine excretion of AQP2, and decreased the $24 \mathrm{~h}$ diuresis while urine osmolality increased. This occurred similarly and persistently in patients who were treated with statins in the long-term, i.e., for at least 1 year (Procino et al., 2015).

Collectively, the data suggest that statins provide novel opportunities for the treatment of X-linked NDI as their target is independent from V2R.

\section{Prostaglandins}

Prostaglandin $\mathrm{E}_{2}\left(\mathrm{PGE}_{2}\right)$ is synthesized and released in the collecting duct (Olesen et al., 2011). It is one of the major cyclooxygenated metabolites of arachidonic acid that stimulates all four $\mathrm{G}$ protein-coupled E-prostanoid receptors, $\mathrm{EP}_{1}-\mathrm{EP}_{4}$ (Hao and Breyer, 2008). $\mathrm{PGE}_{2} / \mathrm{EP}_{1}$ signaling elicits a diuretic response via the $\mathrm{G} \alpha_{\mathrm{q}}$-mediated activation of $\mathrm{PKC}$, triggering AQP2 internalization (Bachteeva et al., 2007). However, an $\mathrm{EP}_{1}$-mediated decrease in $\mathrm{AQP} 2$-induced water permeability was only observed in frog urinary bladder, but not in collecting ducts (Bachteeva et al., 2007). $\mathrm{EP}_{3}$ is coupled to $G \alpha_{i}$ and reduces cAMP synthesis upon activation (Sugimoto et al., 1992), thus decreasing AQP2 expression and membrane localization (Zelenina et al., 2000). $\mathrm{EP}_{3}$-signaling also stimulates RhoA (Tamma et al., 2003b), probably mediated by the $\mathrm{G} \alpha_{12 / 13}$-dependent activation of Rho guanine nucleotide exchange factors (GEFs) (Yamaguchi et al., 2000; Wells et al., 2002). GEFs directly activate RhoA and thus attenuate AQP2 membrane trafficking (Klussmann et al., 2001; Tamma et al., 2001). The activation of the different signaling pathways is most likely due to different $\mathrm{EP}_{3}$ splice variants (Namba et al., 1993; Hatae et al., 2002). The observation of various cellular responses might also be the result of the differential expression of $\mathrm{PGE}_{2}$ receptors in model systems derived from different renal sections of diverse species (Olesen and Fenton, 2013).

$\mathrm{EP}_{2}$ and $\mathrm{EP}_{4}$ couple to $\mathrm{G} \alpha_{\mathrm{s}}$ (Alexander et al., 2011). The stimulation of each receptor results in the increased phosphorylation of AQP2-S264, whose effect is presently unknown (Olesen et al., 2011). Only $\mathrm{EP}_{2}$ signaling increases the cytosolic cAMP concentration AVP-independently (Breyer and Breyer, 2001) and stimulates the phosphorylation of AQP2 at S256 and S269 (Olesen et al., 2011). However, there are contradictory data on whether $\mathrm{EP}_{2}$ is expressed in the collecting duct at all (Sugimoto et al., 1994; Breyer et al., 1996; Morath et al., 1999; Jensen et al., 2001; Regan, 2003; Hao and Breyer, 2008). $\mathrm{EP}_{4}$ is widely spread in the collecting duct (Sugimoto and Narumiya, 2007). Its activation enhances AQP2 membrane trafficking, although the cytosolic cAMP concentration remains unaffected (Olesen et al., 2011). This 
might result from promiscuous $\mathrm{G}$ protein coupling (Fujino and Regan, 2006) which may occur upon PKA phosphorylation of $\mathrm{EP}_{4}$ (Olesen and Fenton, 2013). In line, $\mathrm{EP}_{4}$ activation stimulates phosphatidylinositol 3-kinase (PI3K) (Fujino et al., 2003), which is suggested to regulate AQP2 expression and endosomal retrieval (Tajika et al., 2004; Bustamante et al., 2005). Altogether, the molecular details of $\mathrm{PGE}_{2}$ signaling remain to be completely understood.

Non-steroidal anti-inflammatory drugs (NSAIDs) block the production of $\mathrm{PGE}_{2}$, other prostaglandins and thromboxanes by inhibition of the cyclooxygenases, COX-1 and COX-2 (Jin, 2015). NSAIDs are commonly used in the treatment of pain and inflammation. Their use in cell culture and animal models has shed some light on the role of prostaglandins such as $\mathrm{PGE}_{2}$ in the control of water homeostasis (Baggaley et al., 2010; Jia et al., 2012; Kortenoeven et al., 2012a).

Recently, effects of the chronic use of the NSAIDs, ibuprofen and meloxicam, on AQP2 were investigated in kidneys from Sprague-Dawley rats. The daily application of the drugs enhanced urine output and significantly reduced urine osmolality after 7-14 days. In line, both drugs significantly reduced the AQP2 protein abundance by $60-70 \%$. Meloxicam significantly increased AQP2 phosphorylated at S256 and S261, whereas ibuprofen increased the AQP2 phosphorylated at S256 but did not affect the phosphorylation of AQP2 at S261. Both ibuprofen and meloxicam increased the phosphorylation of AQP2 at S264 and S269. The observed alterations in the C-terminal phosphorylations of AQP2 may partially compensate for the decrease in AQP2 abundance by promoting its membrane localization and thereby permitting only a limited effect on urine osmolality (Ren et al., 2015).

Indomethacin enhances the antidiuretic activity of AVP and markedly reduces urine output by increasing the AQP2 plasma membrane insertion. This effect of indomethacin is additive with that of thiazide diuretics (Kim et al., 2004b).

In a study where male Wistar rats were treated with indomethacin, ibuprofen and meloxicam AQP2 expression was significantly decreased in water-restricted rats but $\mathrm{PGE}_{2}$ excretion did not significantly change. This effect was less pronounced in water-loaded rats and meloxicam had no significant effect. The stronger effect of NSAIDs on the AQP2 protein level during water restriction seems most relevant for elderly and severely ill patients who are prone to dehydration (Baggaley et al., 2010; Lauridsen et al., 2010).

Stimulation of $\mathrm{EP}_{2}$ and $\mathrm{EP}_{4}$ increases $\mathrm{AQP} 2$ trafficking via increased cAMP. The $\mathrm{EP}_{2}$ agonist, butaprost relieved symptoms of NDI in a rat model (Gao et al., 2015; Olesen et al., 2011). Pharmacological blocking of V2R in rats results in NDI, which could be greatly mitigated via the administration of an $\mathrm{EP}_{2}$ agonist. $\mathrm{EP}_{2}$ agonists are already used in the treatment of dysmenorrhea (Moeller et al., 2013). Moreover, selective $\mathrm{EP}_{4}$ agonists relieved NDI symptoms developed in V2R genedeficient mice (Bockenhauer and Bichet, 2014). In a mouse model for X-linked NDI, an $\mathrm{EP}_{4}$ receptor agonist, [ONO-AE329 (ONO)] efficiently increased urine osmolality and reduced polyuria.
Taken together a possible strategy for the treatment of NDI might be the stimulation of $\mathrm{EP}_{2}$ and/or $\mathrm{EP}_{4}$ and simultaneous blocking of $\mathrm{EP}_{3}$.

$\mathrm{PGE}_{2}$ is particularly important for lithium-induced diabetes insipidus. Increased expression of COX-2 and abnormally high urinary excretion of $\mathrm{PGE}_{2}$ has been noted in animal models suffering from lithium-induced NDI. Lithium-treated patients have elevated urine $\mathrm{PGE}_{2}$ excretion as well (Kim et al., 2008). Administration of COX-2 inhibitors to adult mice and rats relieved the lithium-associated polyuria. Indomethacin blocks prostaglandin production in lithium-treated mpkCCD cells. Additionally, $\mathrm{PGE}_{2}$ synthase-1 (mPGES-1)-deficient mice did not develop lithium-associated polyuria (Jia et al., 2009; Baggaley et al., 2010; Kjaersgaard et al., 2014). In clinical practice inhibition of prostaglandin synthesis with NSAIDs remains an effective therapy for lithium-induced NDI (Kortenoeven et al., 2012a).

\section{PDE Inhibitors}

An increase in cGMP levels, e.g., by ANP or the nitric oxide (NO) donor sodium nitroprusside activates protein kinase G (PKG). PKG can phosphorylate AQP2 at S256 to induce its redistribution into the plasma membrane (Bouley et al., 2000). PDE5 specifically hydrolyses cGMP and thereby prevents cGMP/PKG signaling. PDE5 is present in the principal cells of the collecting duct along with further PDEs, including PDE1 and PDE4 (Dousa, 1999). Inhibition of PDE5, in particular with sildenafil (Viagra) causes AQP2 plasma membrane accumulation in LLC-PK 1 cells. This effect was attributed to the activation of the NO/cGMP pathway (Bouley et al., 2000, 2005) as also sodium nitroprusside, L-arginine (a precursor of NO) and ANP induce plasma membrane accumulation of AQP2 in vitro, and ANP also in vivo (Brown et al., 2012). In line, mice deficient in NO synthase isoforms developed NDI (Morishita et al., 2005a). PDE5 inhibitors and ANP combined cause natriuresis and decreased urine output (Bouley et al., 2005; Assadi and Ghane Sharbaf, 2015). Therefore, the activation of AVP-independent cGMP signaling with sildenafil could be an option in the treatment of X-linked NDI as it bypasses the defective V2R/cAMP axis (Sanches et al., 2012). Sildenafil is already used for the treatment of erectile dysfunction, pulmonary hypertension and subarachnoid hemorrhage.

The PDE4 family of enzymes (PDE4A, PDE4B, PDE4C, and PDE4D) encodes more than 20 isozymes (Houslay, 2010; Klussmann, 2015). Rolipram selectively inhibits the PDE4 isozymes by targeting the catalytic domain of the enzymes. Rolipram enhances the AVP-induced accumulation of cAMP, the translocation of AQP2 into the plasma membrane and the osmotic water permeability of cultured IMCD cells (Stefan et al., 2007). Moreover, rolipram increased urine osmolality in a mouse model of autosomal dominant NDI (Sohara et al., 2006b). However, the clinical trial with rolipram failed (Bichet et al., 1990) because of its intolerable side effects, mainly nausea and vomiting. Recently, roflumilast, and apremilast, both nonselective inhibitors of PDE4A-D, with fewer side effects reached the market. Roflumilast is approved for the treatment of chronic 
obstructive pulmonary disease (COPD) and apremilast for psoriatic arthritis (Klussmann, 2015). These new PDE4 inhibitors may provide a new opportunity for the therapy of X-linked NDI.

\section{Pharmacological Chaperones}

Cell-permeable pharmacological chaperons have proven their efficacy in restoring the plasma membrane localization and functional rescue of V2R. Vaptans (see below) not only block the V2R but can also act as such chaperones. The cellpermeable V2R antagonists S121463 and VPA-985 stabilize ERretained V2R mutants, so that the receptor can be released from the ER and inserted into the plasma membrane (Morello et al., 2000; Wüller et al., 2004). These positive effects of pharmacological chaperons were reproducible in Madin-Darby canine kidney (MDCK) cells overexpressing nine ER-retained V2R mutants involved in NDI (Robben et al., 2006). SR49059 (Conivaptan), a non-selective blocker of V2R and vasopressin V1a receptors (Bernier et al., 2004), has been tested in NDI patients where it decreased urine output and was thus suggested for the treatment of X-linked NDI (Bernier et al., 2006). The chaperones are active in nanomolar concentrations on cultured cells. Regarding NDI treatment the high affinity OPC31260 (mozavaptan) and OPC41061 (tolvaptan) nonpeptidic antagonists would promise beneficial effects in terms of V2R rescue, low doses and efficient substitution for AVP (Robben et al., 2007; Wesche et al., 2012). On the other hand, since low affinity antagonists require higher doses for clinical efficacy this could lead to hepatic toxicity because of potential interference with cytochrome P450 systems. Hence, further studies using modified antagonists or treatment regimes are required.

Vice versa, agonists binding to V2R mutants induced the production of sufficient amounts of cAMP and the translocation of AQP2 into the apical plasma membrane of renal cells. Biased agonists of the V2R represent a novel therapeutic strategy for the treatment of congenital NDI. The non-peptidic agonists MCF14 (OPC23h), MCF18 (VNA932), and MCF57 are full agonist of the V2R but do not induce receptor internalization and arrestin-associated signaling. From a clinical perspective these properties can be of great importance as they can have long-lasting effects (Mouillac and Mendre, 2014).

Both strategies with antagonists or agonists are not applicable if $\mathrm{V} 2 \mathrm{R}$ is not at least partially functional or if it is insensitive to such agents (Moeller et al., 2013; Bockenhauer and Bichet, 2014).

\section{Activators of the AQP2 Shuttle}

An unbiased screening of 3646 compounds for stimulators of the redistribution of AQP2 to the apical plasma membrane of LLC-PK 1 cells identified the JAK-2 and EGFR inhibitor AG-490. The molecule induced the AQP2 accumulation at the plasma membranes of LLC-PK 1 and Madin-Darby canine kidney (MDCK) cells and at that of principal cells in rat kidney sections. AG-490 treatment of AVPdeficient Brattleboro rats improved their urine concentrating capacity within $2 \mathrm{~h}$ (Nomura et al., 2014; Sands and Blount, 2014).

\section{PHARMACOLOGICAL TREATMENTS OF WATER BALANCE DISORDERS WITH ENHANCED AVP-MEDIATED WATER REABSORPTION AND NOVEL AVENUES FOR THERAPY}

\section{Vaptans}

Vaptans, also termed aquaretics, comprise a family of V2R antagonists. They include intravenously administered conivaptan and oral vaptans like tolvaptan, lixivaptan, and satavaptan (Narayen and Mandal, 2012). Tolvaptan, the most extensively used vaptan, selectively inhibits the binding of AVP to the V2R with an almost two times higher affinity than AVP, and interferes with the AQP2 redistribution into the plasma membrane of collecting duct principal cells (Sato et al., 2014). Patients treated with tolvaptan have increased urine AQP2 levels (Sato et al., 2014), indicative of shedding of AQP2 from the apical plasma membrane into the urine.

The aquaretic effect is achieved by enhanced free water clearance without induction of natriuresis, kaliuresis or changes of the glomerular filtration rate (Graziani et al., 2014). Vaptans are approved for the therapy of hypervolemic (heart failure, liver cirrhosis, SIADH) (Narayen and Mandal, 2012) and normovolemic hyponatremia, and since recently for autosomal dominant polycystic kidney disease (Lin et al., 2014; Blair and Keating, 2015). In particular, the adjustment of sodium levels in patients suffering from SIADH and hyponatremia can be easier controlled with vaptans than with conventional hypertonic saline infusions. This translates into a better safety profile, and a lower risk of side effects (Nathan, 2007). Heart failure patients are treated with conventional anti-hypertensive drugs and only since recently additionally with $\mathrm{V} 2$ receptor antagonists (vaptans, see below) if hospitalized (Gilotra and Russell, 2014). More than half of the cirrhosis patients suffer from ascites, a major complication associated with sodium and AVP-dependent water retention that is characterized by the accumulation of fluid in the abdominal cavity. Hence, V2R antagonists could prove beneficial in the symptomatic treatment of this condition by increasing urine output (Yan et al., 2015).

\section{Demeclocycline}

Demeclocycline, a bacteriostatic antibiotic of the tetracycline group, is used for the treatment of sustained hyponatremia in patients with SIADH. It is the first choice in this case because of its aquaretic effect. Demeclocycline decreases the AVP-induced cAMP production and abundance of adenylyl cyclases 3 and 5/6, and reduces the expression of AQP2 in the apical plasma membrane of mpkCCD cells without affecting the V2R. In a rat model of SIADH, demeclocycline increased urine volume, decreased urine osmolality and alleviated hyponatremia as has been shown in patients (Kortenoeven et al., 2013). Other tetracycline antibiotics including minocycline, doxycycline and tetracycline have similar effects with regard to reducing urine volume in toads (Feldman and Singer, 1974; Hirji and Mucklow, 1991). Tetracycline reduces urinary concentrating ability also in humans (Wilson et al., 1973). However, demeclocycline 
(600-1200 mg/day) may also cause NDI in some patients, and that is the reason for the limited application of these drugs in clinical practice (Gross, 2012).

\section{PHARMACOLOGICAL TARGETING OF PROTEIN-PROTEIN INTERACTIONS FOR INTERFERENCE WITH AQP2 TRAFFICKING}

Protein-protein interactions play key roles in all biological processes. They are diverse and highly specific and, therefore, provide ample opportunities for the development of novel drugs (Jones and Thornton, 1996; Klussmann and Rosenthal, 2008; Cho et al., 2016). Since AKAP-PKA interactions are involved in AQP2 trafficking (Klussmann et al., 1999; Klussmann and Rosenthal, 2001), their disruption may lead to a new concept for the treatment of diseases characterized by excessive AVPmediated water retention such as heart failure (Nedvetsky et al., 2009; Tröger et al., 2012; Deak and Klussmann, 2015; Dema et al., 2015). Indeed, peptides, peptidomimetics, and small molecules for the non-selective disruption of AKAPPKA interactions are available (Hundsrucker et al., 2006a,b; Hundsrucker and Klussmann, 2008; Christian et al., 2011; Schäfer et al., 2013; Schächterle et al., 2015). All of these agents target the AKAP-binding domain of regulatory $\mathrm{R}$ subunits of PKA, the dimerization/docking (D/D) domain. They bind competitively and thereby prevent the interactions of $\mathrm{R}$ subunits with AKAPs (Deak and Klussmann, 2015). The peptides such as Ht31, AKAP18-derived peptides or AKAP Is all bind R subunits with high affinity and thereby effectively disrupt AKAP-PKA interactions. However, short half-life, low bioavailability, and membrane permeability limit the development of peptide-based drugs, although several peptide-drugs reached the market (Otvos and Wade, 2014). The available peptidomimetics are low affinity binders and require a multistep synthesis. They would require further optimization prior to becoming candidates for drug development (Dema et al., 2015). Most promising are small molecule inhibitors of protein-protein interactions. With good bioavailability and enhanced plasma membrane permeability they can be optimized toward effective inhibitors. However, the development is challenging, because protein-protein interaction interfaces are generally large and shallow and can hardly be completely covered by small molecules. Despite this, in the past years remarkable progress has been made and several small molecule inhibitors of protein-protein interactions were discovered (Sheng et al., 2015). The only small molecule inhibiting AKAP-PKA interactions, FMP-API-1, is not suitable for further development toward a drug candidate as it also activates PKA (Christian et al., 2011; Yu et al., 2014).

In order to identify small molecule inhibitors of the AVPinduced redistribution of AQP2, high-throughput screening of small molecule libraries provides ample opportunities. A prototypical example is a screening of 17,700 small molecules for inhibitors of the cAMP-induced redistribution of AQP2 using a cell-based assay (Bogum et al., 2013). This approach yielded 17 inhibitors, among them, 4-acetyldiphyllin (4-AD) a selective blocker of V-ATPase. 4AD increased $\mathrm{pH}$ levels of intracellular vesicles and caused an accumulation of AQP2 in the Golgi. The compound prevented the PKA-induced phosphorylation of AQP2 at S256 without affecting cAMP levels, PKA activity or the phosphorylations of AQP2 at S261 and S269. Although the screening approach did not yield an inhibitor of PPIs, it is suitable for identification of small molecules that may serve as a starting point for the development of novel drug candidates for the therapy of disorders associated with increased AQP2 levels (Bogum et al., 2013).

\section{SUMMARY AND OUTLOOK}

The localization of AQP2 is critical for the reabsorption of water. If located in the plasma membrane of renal collecting duct principal cells AQP2 facilitates water reabsorption from primary urine. A predominant localization in the plasma membrane contributes to excessive water retention as in heart failure, SIADH or liver cirrhosis; vice versa a predominant intracellular localization causes diabetes insipidus, a disease characterized by a massive loss of hypotonic urine. A variety of cAMP-dependent and independent signaling pathways and defined protein-protein interactions have been identified that control the localization of AQP2. Considering the still unmet medical need in both classes of diseases, i.e., diseases with a high- or a low-level plasma membrane localization of AQP2, pharmacological targeting of the mechanisms controlling AQP2 trafficking provides ample opportunities for the development of novel drugs.

Several established drugs modulate the localization of AQP2 in animal models, and first data from patients confirmed these effects. Examples are statins that promote or NSAIDs and vaptans that prevent the plasma membrane localization of AQP2. Further clinical trials will have to confirm the value of repurposing such drugs toward the treatment of water balance disorders. However, all of these established drugs cause unwanted side effects, which may limit their use. Therefore, it will be necessary to continue with the identification of molecular mechanisms underlying the control of the localization of AQP2 to provide novel drug targets. In particular, identifying protein-protein interactions that govern the control of AQP2 is relevant as protein-protein interactions are highly specific and diverse and therefore represent a unique class of drug targets. AKAP-PKA interactions that are essential for the AVP-induced redistribution of AQP2 are an example (Christian et al., 2011; Schächterle et al., 2015). It is important to define "hot spots" within the interacting surfaces, i.e., crucial amino acids that mediate the interaction and that can be targeted with small molecules for effective disruption (Buchwald, 2010; Villoutreix et al., 2014; Sheng et al., 2015). For identifying small molecule inhibitors of protein-protein interactions highthroughput screening may be used. This approach has led to the identification of FMP-API-1, the first small molecule disruptor of AKAP-PKA interactions (Keskin et al., 2008; Christian et al., 2011).

Other unbiased screening approaches have identified small molecule modulators of the AVP-induced redistribution of AQP2. The identification of the inhibitor 4AD for example provided new insight into the regulation of AQP2. It identified 
V-ATPase as a protein involved in the control of AQP2 (Bogum et al., 2013). Another example is the identification of a small molecule activator of the AQP2 redistribution, AG-490. AG490 inhibits the EGF receptor and JAK-2 kinase (Nomura et al., 2014). Even though targeting a ubiquitous protein such as VATPase or the EGF receptor may not be an option for the treatment of patients, the screening approaches are valuable for the identification of new molecules and targets and may provide new starting points for the development of novel drugs for the treatment of water balance disorders.

Taken together, many questions surrounding water balance disorders have been answered but even more remain unanswered. A particular topic in the future will be to translate the insights into molecular mechanisms underlying the trafficking of AQP2 into novel therapies for these diseases with their unmet medical needs.

\section{REFERENCES}

Agarwal, S. K., and Gupta, A. (2008). Aquaporins: the renal water channels. Indian J. Nephrol. 18, 95-100. doi: 10.4103/0971-4065.43687

Alexander, S. P., Mathie, A., and Peters, J. A. (2011). Guide to Receptors and Channels (GRAC), 5th edition. Br. J. Pharmacol. 164(Suppl. 1), S1-S324. doi: 10.1111/j.1476-5381.2011.01649_1.x

Ananthakrishnan, S. (2009). Diabetes insipidus in pregnancy: etiology, evaluation, and management. Endocr. Pract. 15, 377-382. doi: 10.4158/EP09090.RA

Aoki, T., Suzuki, T., Hagiwara, H., Kuwahara, M., Sasaki, S., Takata, K., et al. (2012). Close association of aquaporin-2 internalization with caveolin-1. Acta Histochem. Cytochem. 45, 139-146. doi: 10.1267/ahc.12003

Apostol, E., Ecelbarger, C. A., Terris, J., Bradford, A. D., Andrews, P., and Knepper, M. A. (1997). Reduced renal medullary water channel expression in puromycin aminonucleoside-induced nephrotic syndrome. J. Am. Soc. Nephrol. JASN 8, $15-24$.

Arrighi, S., and Aralla, M. (2014). Immunolocalization of aquaporin water channels in the domestic cat male genital tract. Reprod. Domest. Anim. 49, 17-26. doi: 10.1111/rda.12213

Arthus, M. F., Lonergan, M., Crumley, M. J., Naumova, A. K., Morin, D., De Marco, L. A., et al. (2000). Report of 33 novel AVPR2 mutations and analysis of 117 families with X-linked nephrogenic diabetes insipidus. J. Am. Soc. Nephrol. 11, 1044-1054.

Assadi, F., and Ghane Sharbaf, F. G. (2015). Sildenafil for the treatment of congenital nephrogenic diabetes insipidus. Am. J. Nephrol. 42, 65-69. doi: $10.1159 / 000439065$

Bachteeva, V., Fock, E., Lavrova, E., Nikolaeva, S., Gambaryan, S., and Parnova, R. (2007). Prostaglandin E2 inhibits vasotocin-induced osmotic water permeability in the frog urinary bladder by EP1-receptor-mediated activation of NO/cGMP pathway. Am. J. Physiol. Regul. Integr. Comp. Physiol. 293, R528-R537. doi: 10.1152/ajpregu.00811.2006

Baggaley, E., Nielsen, S., and Marples, D. (2010). Dehydration-induced increase in aquaporin-2 protein abundance is blocked by nonsteroidal antiinflammatory drugs. Am. J. Physiol. Renal Physiol. 298, F1051-F1058. doi: 10.1152/ajprenal.90202.2008

Bagnasco, S. M. (2012). Protein kinase C-alpha comes to the rescue of aquaporin-2. Am. J. Physiol. Renal. Physiol. 303, F35-F36. doi: 10.1152/ajprenal.00225.2012

Bai, C., Fukuda, N., Song, Y., Ma, T., Matthay, M. A., and Verkman, A. S. (1999). Lung fluid transport in aquaporin-1 and aquaporin-4 knockout mice. J. Clin. Invest. 103, 555-561. doi: 10.1172/JCI4138

Barile, M., Pisitkun, T., Yu, M. J., Chou, C. L., Verbalis, M. J., Shen, R. F., et al. (2005). Large scale protein identification in intracellular aquaporin-2 vesicles from renal inner medullary collecting duct. Mol. Cell. Proteomics 4, 1095-1106. doi: $10.1074 /$ mcp.M500049-MCP200

\section{AUTHOR CONTRIBUTIONS}

TV and MS contributed equally. TV wrote most of the pharmacology section, MS most of the section relating to molecular mechanisms underlying AQP2 trafficking and the figures. DF contributed the tables and to sections about AQP2 trafficking. EK designed the study wrote parts of all sections and edited the manuscript.

\section{FUNDING}

This work was supported by grants from the Else KrönerFresenius-Stiftung (2013_A145), the German-Israeli Foundation (G.I.F. I-1210-286.13/2012), and the German Centre for Cardiovascular Research (DZHK 81X210012) to EK.

Barron, W. M., Cohen, L. H., Ulland, L. A., Lassiter, W. E., Fulghum, E. M., Emmanouel, D., et al. (1984). Transient vasopressin-resistant diabetes insipidus of pregnancy. N. Engl. J. Med. 310, 442-444. doi: 10.1056/NEJM198402163100707

Bedford, J. J., Weggery, S., Ellis, G., McDonald, F. J., Joyce, P. R., Leader, J. P., et al. (2008). Lithium-induced nephrogenic diabetes insipidus: renal effects of amiloride. Clin. J. Am. Soc. Nephrol. 3, 1324-1331. doi: 10.2215/CJN.016 40408

Bernier, V., Lagacé, M., Lonergan, M., Arthus, M. F., Bichet, D. G., and Bouvier, M. (2004). Functional rescue of the constitutively internalized V2 vasopressin receptor mutant R137H by the pharmacological chaperone action of SR49059. Mol. Endocrinol. 18, 2074-2084. doi: 10.1210/me.2004-0080

Bernier, V., Morello, J. P., Zarruk, A., Debrand, N., Salahpour, A., Lonergan, M., et al. (2006). Pharmacologic chaperones as a potential treatment for Xlinked nephrogenic diabetes insipidus. J Am. Soc. Nephrol. 17, 232-243. doi: 10.1681/ASN.2005080854

Bichet, D. G., Arthus, M. F., Lonergan, M., Hendy, G. N., Paradis, A. J., Fujiwara, T. M., et al. (1993). X-linked nephrogenic diabetes insipidus mutations in North America and the Hopewell hypothesis. J. Clin. Invest. 92, 1262-1268. doi: $10.1172 /$ JCI116698

Bichet, D. G., Hendy, G. N., Lonergan, M., Arthus, M. F., Ligier, S., Pausova, Z., et al. (1992). X-linked nephrogenic diabetes insipidus: from the ship Hopewell to RFLP studies. Am. J. Hum. Genet. 51, 1089-1102.

Bichet, D. G., Ruel, N., Arthus, M. F., and Lonergan, M. (1990). Rolipram, a phosphodiesterase inhibitor, in the treatment of two male patients with congenital nephrogenic diabetes insipidus. Nephron 56, 449-450. doi: $10.1159 / 000186196$

Bienert, G. P., Møller, A. L., Kristiansen, K. A., Schulz, A., Møller, I. M., Schjoerring, J. K., et al. (2007). Specific aquaporins facilitate the diffusion of hydrogen peroxide across membranes. J. Biol. Chem. 282, 1183-1192. doi: 10.1074/jbc.M603761200

Blair, H. A., and Keating, G. M. (2015). Tolvaptan: A review in autosomal dominant polycystic kidney disease. Drugs 75, 1797-1806. doi: 10.1007/s40265015-0475-x

Blount, M. A., Sim, J. H., Zhou, R., Martin, C. F., Lu, W., Sands, J. M., et al. (2010). Expression of transporters involved in urine concentration recovers differently after cessation of lithium treatment. Am. J. Physiol. Renal. Physiol. 298, F601-F608. doi: 10.1152/ajprenal.00424.2009

Bockenhauer, D., and Bichet, D. G. (2014). Urinary concentration: different ways to open and close the tap. Pediatr. Nephrol. 29, 1297-1303. doi: 10.1007/s00467013-2526-4

Bockenhauer, D., and Bichet, D. G. (2015). Pathophysiology, diagnosis and management of nephrogenic diabetes insipidus. Nat. Rev. Nephrol. 11, 576-588. doi: 10.1038/nrneph.2015.89 
Bogum, J., Faust, D., Zühlke, K., Eichhorst, J., Moutty, M. C., Furkert, J., et al. (2013). Small-molecule screening identifies modulators of aquaporin2 trafficking. J. Am. Soc. Nephrol. 24, 744-758. doi: 10.1681/ASN. 2012030295

Bonfrate, L., Procino, G., Wang, D. Q., Svelto, M., and Portincasa, P. (2015). A novel therapeutic effect of statins on nephrogenic diabetes insipidus. J. Cell. Mol. Med. 19, 265-282. doi: 10.1111/jcmm.12422

Boone, M., and Deen, P. M. (2009). Congenital nephrogenic diabetes insipidus: what can we learn from mouse models? Exp. Physiol. 94, 186-190. doi: 10.1113/expphysiol.2008.043000

Boone, M., Kortenoeven, M. L. A., Robben, J. H., Tamma, G., and Deen, P. M. T. (2011). Counteracting vasopressin-mediated water reabsorption by ATP, dopamine, and phorbol esters: mechanisms of action. Am. J. Physiol. Renal Physiol. 300, F761-F771. doi: 10.1152/ajprenal.00247.2010

Boone, M., Mobasheri, A., Fenton, R. A., van Balkom, B. W., Wismans, R., van der Zee, C. E., et al. (2010). The lysosomal trafficking regulator interacting protein-5 localizes mainly in epithelial cells. J. Mol. Hist. 41, 61-74. doi: 10.1007/s10735-010-9263-9

Bou Matar, R. N., Malik, B., Wang, X. H., Martin, C. F., Eaton, D. C., Sands, J. M., et al. (2012). Protein abundance of urea transporters and aquaporin 2 change differently in nephrotic pair-fed vs. non-pair-fed rats. Am. J. Physiol. Renal Physiol. 302, F1545-F1553. doi: 10.1152/ajprenal.00686.2011

Bouley, R., Breton, S., Sun, T., McLaughlin, M., Nsumu, N. N., Lin, H. Y., et al. (2000). Nitric oxide and atrial natriuretic factor stimulate cGMP-dependent membrane insertion of aquaporin 2 in renal epithelial cells. J. Clin. Invest. 106, 1115-1126. doi: 10.1172/JCI9594

Bouley, R., Hasler, U., Lu, H. A., Nunes, P., and Brown, D. (2008). Bypassing vasopressin receptor signaling pathways in nephrogenic diabetes insipidus. Semin. Nephrol. 28, 266-278. doi: 10.1016/j.semnephrol.2008.03.010

Bouley, R., Hawthorn, G., Russo, L. M., Lin, H. Y., Ausiello, D. A., and Brown, D. (2006). Aquaporin 2 (AQP2) and vasopressin type 2 receptor (V2R) endocytosis in kidney epithelial cells: AQP2 is located in 'endocytosis-resistant' membrane domains after vasopressin treatment. Biol. Cell 98, 215-232. doi: 10.1042/BC20040054

Bouley, R., Lu, H. A., Nunes, P., Da Silva, N., McLaughlin, M., Chen, Y., et al. (2011). Calcitonin has a vasopressin-like effect on aquaporin-2 trafficking and urinary concentration. J. Am. Soc. Nephrol. 22, 59-72. doi: 10.1681/ASN.2009121267

Bouley, R., Pastor-Soler, N., Cohen, O., McLaughlin, M., Breton, S., and Brown, D. (2005). Stimulation of AQP2 membrane insertion in renal epithelial cells in vitro and in vivo by the cGMP phosphodiesterase inhibitor sildenafil citrate (Viagra). Am. J. Physiol. Renal Physiol. 288, F1103-F1112. doi: 10.1152/ajprenal.00337.2004

Braun, M. M., Barstow, C. H., and Pyzocha, N. J. (2015). Diagnosis and management of sodium disorders: hyponatremia and hypernatremia. Am. Fam. Physician 91, 299-307.

Breton, S., and Brown, D. (1998). Cold-induced microtubule disruption and relocalization of membrane proteins in kidney epithelial cells. J. Am. Soc. Nephrol. 9, 155-166.

Breyer, M. D., and Breyer, R. M. (2001). G protein-coupled prostanoid receptors and the kidney. Ann. Rev. Physiol. 63, 579-605. doi: 10.1146/annurev.physiol.63.1.579

Breyer, M. D., Davis, L., Jacobson, H. R., and Breyer, R. M. (1996). Differential localization of prostaglandin $\mathrm{E}$ receptor subtypes in human kidney. Am. J. Physiol. Renal Physiol. 270, F912-918.

Brønd, L., Hadrup, N., Salling, N., Torp, M., Graebe, M., Christensen, S., et al. (2004). Uncoupling of vasopressin signaling in collecting ducts from rats with CBL-induced liver cirrhosis. Am. J. Physiol. Renal Physiol. 287, F806-F815. doi: 10.1152/ajprenal.00278.2003

Brønd, L., Müllertz, K. M., Torp, M., Nielsen, J., Graebe, M., Hadrup, N., et al. (2013). Congestive heart failure in rats is associated with increased collecting duct vasopressin sensitivity and vasopressin type 2 receptor reexternalization. Am. J. Physiol. Renal Physiol. 305, F1547-F1554. doi: 10.1152/ajprenal.00461.2012

Brooks, H. L., Ageloff, S., Kwon, T. H., Brandt, W., Terris, J. M., Seth, A., et al. (2003). cDNA array identification of genes regulated in rat renal medulla in response to vasopressin infusion. Am. J. Physiol. Renal Physiol. 284, F218-F228. doi: 10.1152/ajprenal.00054.2002
Brown, D., Bouley, R., Paunescu, T. G., Breton, S., and Lu, H. A. (2012). New insights into the dynamic regulation of water and acid-base balance by renal epithelial cells. Am. J. Physiol. Cell Physiol. 302, C1421-C1433. doi: 10.1152/ajpcell.00085.2012

Brown, D., Hasler, U., Nunes, P., Bouley, R., and Lu, H. A. (2008). Phosphorylation events and the modulation of aquaporin 2 cell surface expression. Curr. Opin. Nephrol. Hypertens. 17, 491-498. doi: 10.1097/MNH.0b013e3283094eb1

Brunati, A. M., Marin, O., Bisinella, A., Salviati, A., and Pinna, L. A. (2000). Novel consensus sequence for the Golgi apparatus casein kinase, revealed using proline-rich protein-1 (PRP1)-derived peptide substrates. Biochem. J. 351(Pt 3), 765-768. doi: 10.1042/bj3510765

Buchwald, P. (2010). Small-molecule protein-protein interaction inhibitors: therapeutic potential in light of molecular size, chemical space, and ligand binding efficiency considerations. IUBMB Life 62, 724-731. doi: 10.1002/iub.383

Bustamante, M., Hasler, U., Kotova, O., Chibalin, A. V., Mordasini, D., Rousselot, M., et al. (2005). Insulin potentiates AVP-induced AQP2 expression in cultured renal collecting duct principal cells. Am. J. Physiol. Renal Physiol. 288, F334F344. doi: 10.1152/ajprenal.00180.2004

Cai, Q., Nelson, S. K., McReynolds, M. R., Diamond-Stanic, M. K., Elliott, D., and Brooks, H. L. (2010). Vasopressin increases expression of UT-A1, UTA3, and ER chaperone GRP78 in the renal medulla of mice with a urinary concentrating defect. Am. J. Physiol. Renal Physiol. 299, F712-F719. doi: 10.1152/ajprenal.00690.2009

Celik, G., Ozturk, E., Ipekci, S. H., Yilmaz, S., Colkesen, F., Baldane, S., et al. (2014). An uncommon presentation of Sjogren's syndrome and brucellosis. Transfus. Apher. Sci. 51, 77-80. doi: 10.1016/j.transci.2014.03.011

Cen, J., Nie, M., Duan, L., and Gu, F. (2015). Novel autosomal recessive gene mutations in aquaporin-2 in two Chinese congenital nephrogenic diabetes insipidus pedigrees. Int. J. Clin. Exp. Med. 8, 3629-3639.

Chen, Y., Rice, W., Gu, Z., Li, J., Huang, J., Brenner, M. B., et al. (2012). Aquaporin 2 promotes cell migration and epithelial morphogenesis. J. Am. Soc. Nephrol. 23, 1506-1517. doi: 10.1681/asn.2012010079

Cho, W., Kim, H., and Hu, Y. (2016). High-throughput fluorometric assay for membrane-protein interaction. Methods Mol. Biol. 1376, 163-174. doi: 10.1007/978-1-4939-3170-5_14

Chou, C. L., Christensen, B. M., Frische, S., Vorum, H., Desai, R. A., Hoffert, J. D., et al. (2004). Non-muscle myosin II and myosin light chain kinase are downstream targets for vasopressin signaling in the renal collecting duct. J. Biol. Chem. 279, 49026-49035. doi: 10.1074/jbc.M408565200

Christian, F., Szaszák, M., Friedl, S., Drewianka, S., Lorenz, D., Goncalves, A., et al. (2011). Small molecule AKAP-protein kinase A (PKA) interaction disruptors that activate PKA interfere with compartmentalized cAMP signaling in cardiac myocytes. J. Biol. Chem. 286, 9079-9096. doi: 10.1074/jbc.M110. 160614

Chung, S. H., Jun, D. W., Kim, K. T., Chae, J. D., Park, E. K., Son, B. K., et al. (2010). Aquaporin-2 urinary excretion in cirrhosis: relationship to vasopressin and nitric oxide. Dig. Dis. Sci. 55, 1135-1141. doi: 10.1007/s10620-009-0829-X

Cui, X., Zhang, J., Li, Y., Sun, Y., Cao, J., Zhao, M., et al. (2015). Effects of Qili Qiangxin Capsule on AQP2, V2R, and AT1R in rats with chronic heart failure. Evid. Based Complement. Alternat. Med. 2015:639450. doi: $10.1155 / 2015 / 639450$

Danilovic, A., Lopes, R. I., Sanches, T. R., Shimizu, M. H., Oshiro, F. M., Andrade, L., et al. (2012). Atorvastatin prevents the downregulation of aquaporin-2 receptor after bilateral ureteral obstruction and protects renal function in a rat model. Urology 80, 485 e415-e420. doi: 10.1016/j.urology.2012.02.021

Davison, J. M., Sheills, E. A., Barron, W. M., Robinson, A. G., and Lindheimer, M. D. (1989). Changes in the metabolic clearance of vasopressin and in plasma vasopressinase throughout human pregnancy. J. Clin. Invest. 83, 1313-1318. doi: 10.1172/JCI114017

de Mattia, F., Savelkoul, P. J., Kamsteeg, E. J., Konings, I. B., van der Sluijs, P., Mallmann, R., et al. (2005). Lack of arginine vasopressin-induced phosphorylation of aquaporin-2 mutant AQP2-R254L explains dominant nephrogenic diabetes insipidus. J. Am. Soc. Nephrol. 16, 2872-2880. doi: 10.1681/ASN.2005010104

Deak, V. A., and Klussmann, E. (2015). Pharmacological interference with proteinprotein interactions of A-kinase anchoring proteins as a strategy for the treatment of disease. Curr. Drug Targets. 
Deen, P. M., Croes, H., van Aubel, R. A., Ginsel, L. A., and van Os, C. H. (1995). Water channels encoded by mutant aquaporin-2 genes in nephrogenic diabetes insipidus are impaired in their cellular routing. J. Clin. Invest. 95, 2291-2296. doi: 10.1172/JCI117920

Deen, P. M., Weghuis, D. O., Sinke, R. J., Geurts van Kessel, A., Wieringa, B., and van Os, C. H. (1994). Assignment of the human gene for the water channel of renal collecting duct Aquaporin 2 (AQP2) to chromosome 12 region q12->q13. Cytogenet. Cell Genet. 66, 260-262. doi: 10.1159/000133707

Dema, A., Perets, E., Schulz, M. S., Deák, V. A., and Klussmann, E. (2015). Pharmacological targeting of AKAP-directed compartmentalized cAMP signalling. Cell. Signal. 27, 2474-2487. doi: 10.1016/j.cellsig.2015.09.008

Dong, J. M., Leung, T., Manser, E., and Lim, L. (1998). cAMP-induced morphological changes are counteracted by the activated RhoA small GTPase and the Rho kinase ROKalpha. J. Biol. Chem. 273, 22554-22562. doi: 10.1074/jbc.273.35.22554

Douglass, J., Gunaratne, R., Bradford, D., Saeed, F., Hoffert, J. D., Steinbach, P. J., et al. (2012). Identifying protein kinase target preferences using mass spectrometry. Am. J. Physiol. Cell Physiol. 303, C715-C727. doi: 10.1152/ajpcell.00166.2012

Dousa, T. P. (1999). Cyclic- $3^{\prime}, 5^{\prime}$-nucleotide phosphodiesterase isozymes in cell biology and pathophysiology of the kidney. Kidney Int. 55, 29-62. doi: 10.1046/j.1523-1755.1999.00233.x

Durr, J. A., Hoggard, J. G., Hunt, J. M., and Schrier, R. W. (1987). Diabetes insipidus in pregnancy associated with abnormally high circulating vasopressinase activity. N. Engl. J. Med. 316, 1070-1074. doi: 10.1056/NEJM198704233161707

Ecelbarger, C. A., Chou, C. L., Lee, A. J., DiGiovanni, S. R., Verbalis, J. G., and Knepper, M. A. (1998). Escape from vasopressin-induced antidiuresis: role of vasopressin resistance of the collecting duct. Am. J. Physiol. 274, F1161-F1166.

Ecelbarger, C. A., Terris, J., Frindt, G., Echevarria, M., Marples, D., Nielsen, S., et al. (1995). Aquaporin-3 water channel localization and regulation in rat kidney. Am. J. Physiol. Renal Physiol. 269, F663-F672.

Echevarria, M., Windhager, E. E., Tate, S. S., and Frindt, G. (1994). Cloning and expression of AQP3, a water channel from the medullary collecting duct of rat kidney. Proc. Natl. Acad. Sci. U.S.A. 91, 10997-11001. doi: 10.1073/pnas.91.23.10997

Edwards, R. M., and Brooks, D. P. (2001). Dopamine inhibits vasopressin action in the rat inner medullary collecting duct via alpha(2)-adrenoceptors. J. Pharmacol. Exp. Ther. 298, 1001-1006.

Elkjaer, M. L., Nejsum, L. N., Gresz, V., Kwon, T. H., Jensen, U. B., Frøkiaer, J., et al. (2001). Immunolocalization of aquaporin-8 in rat kidney, gastrointestinal tract, testis, and airways. Am. J. Physiol. Renal Physiol. 281, F1047-F1057. doi: 10.1152/ajprenal.0158.2001

Ellidokuz, E., Uslan, I., Demir, S., Cevrioglu, S., and Tufan, G. (2006). Transient postpartum diabetes insipidus associated with HELLP syndrome. J. Obstet. Gynaecol. Res. 32, 602-604. doi: 10.1111/j.1447-0756.2006.00464.x

Feldman, B. J., Rosenthal, S. M., Vargas, G. A., Fenwick, R. G., Huang, E. A., Matsuda-Abedini, M., et al. (2005). Nephrogenic syndrome of inappropriate antidiuresis. N. Engl. J. Med. 352, 1884-1890. doi: 10.1056/NEJMoa042743

Feldman, H. A., and Singer, I. (1974). Comparative effects of tetracyclines on water flow across toad urinary bladders. J. Pharmacol. Exp. Ther. 190, 358-364.

Fenske, W., and Allolio, B. (2010). The syndrome of inappropriate secretion of antidiuretic hormone: diagnostic and therapeutic advances. Horm. Metab. Res. 42, 691-702. doi: 10.1055/s-0030-1255117

Fenton, R. A., Moeller, H. B., Hoffert, J. D., Yu, M. J., Nielsen, S., and Knepper, M. A. (2008). Acute regulation of aquaporin-2 phosphorylation at Ser-264 by vasopressin. Proc. Natl. Acad. Sci. U.S.A. 105, 3134-3139. doi: 10.1073/pnas.0712338105

Frank, M., van der Haar, M. E., Schaeren-Wiemers, N., and Schwab, M. E. (1998). rMAL is a glycosphingolipid-associated protein of myelin and apical membranes of epithelial cells in kidney and stomach. J. Neurosci. 18, 4901-4913.

Franki, N., Macaluso, F., Schubert, W., Gunther, L., and Hays, R. M. (1995). Water channel-carrying vesicles in the rat IMCD contain cellubrevin. Am. J. Physiol. Renal Physiol. 269, C797-C801.

Frøkiaer, J., Marples, D., Knepper, M. A., and Nielsen, S. (1996). Bilateral ureteral obstruction downregulates expression of vasopressin-sensitive AQP-2 water channel in rat kidney. Am. J. Physiol. 270, F657-F668.
Fujino, H., and Regan, J. W. (2006). EP(4) prostanoid receptor coupling to a pertussis toxin-sensitive inhibitory G protein. Mol. Pharmacol. 69, 5-10. doi: 10.1124/mol.105.017749

Fujino, H., Xu, W., and Regan, J. W. (2003). Prostaglandin E2 induced functional expression of early growth response factor-1 by EP4, but not EP2, prostanoid receptors via the phosphatidylinositol 3-kinase and extracellular signal-regulated kinases. J. Biol. Chem. 278, 12151-12156. doi: 10.1074/jbc.M212665200

Fujiwara, T. M., and Bichet, D. G. (2005). Molecular biology of hereditary diabetes insipidus. J. Am. Soc. Nephrol. 16, 2836-2846. doi: 10.1681/ASN.2005040371

Fushimi, K., Sasaki, S., and Marumo, F. (1997). Phosphorylation of serine 256 is required for CAMP-dependent regulatory exocytosis of the aquaporin-2 water channel. J. Biol. Chem. 272, 14800-14804. doi: 10.1074/jbc.272.23.14800

Fushimi, K., Uchida, S., Hara, Y., Hirata, Y., Marumo, F., and Sasaki, S. (1993). Cloning and expression of apical membrane water channel of rat kidney collecting tubule. Nature 361, 549-552. doi: 10.1038/361549a0

Galizia, L., Pizzoni, A., Fernandez, J., Rivarola, V., Capurro, C., and Ford, P. (2012). Functional interaction between AQP2 and TRPV4 in renal cells. J. Cell. Biochem. 113, 580-589. doi: 10.1002/jcb.23382

Gao, M., Cao, R., Du, S., Jia, X., Zheng, S., Huang, S., et al. (2015). Disruption of prostaglandin E2 receptor EP4 impairs urinary concentration via decreasing aquaporin 2 in renal collecting ducts. Proc. Natl. Acad. Sci. U.S.A. 112, 8397-8402. doi: 10.1073/pnas.1509565112

Gilotra, N. A., and Russell, S. D. (2014). Arginine vasopressin as a target in the treatment of acute heart failure. World J. Cardiol. 6, 1252-1261. doi: 10.4330/wjc.v6.i12.1252

Goel, M., Sinkins, W. G., Zuo, C. D., Hopfer, U., and Schilling, W. P. (2007). Vasopressin-induced membrane trafficking of TRPC3 and AQP2 channels in cells of the rat renal collecting duct. Am. J. Physiol. Renal Physiol. 293, F1476-F1488. doi: 10.1152/ajprenal.00186.2007

Goel, M., Zuo, C. D., and Schilling, W. P. (2010). Role of cAMP/PKA signaling cascade in vasopressin-induced trafficking of TRPC3 channels in principal cells of the collecting duct. Am. J. Physiol. Renal Physiology 298, F988-FF996. doi: 10.1152/ajprenal.00586.2009

Goji, K., Kuwahara, M., Gu, Y., Matsuo, M., Marumo, F., and Sasaki, S. (1998). Novel mutations in aquaporin-2 gene in female siblings with nephrogenic diabetes insipidus: evidence of disrupted water channel function. J. Clin. Endocrinol. Metab. 83, 3205-3209. doi: 10.1210/jc.83.9.3205

Gooch, J. L. (2006). Loss of calcineurin A results in altered trafficking of AQP2 and in nephrogenic diabetes insipidus. J. Cell. Sci. 119, 2468-2476. doi: $10.1242 /$ jcs. 02971

Gorelick, D. A., Praetorius, J., Tsunenari, T., Nielsen, S., and Agre, P. (2006). Aquaporin-11: a channel protein lacking apparent transport function expressed in brain. BMC Biochem. 7:14. doi: 10.1186/1471-2091-7-14

Gouraud, S. (2002). Functional involvement of VAMP/synaptobrevin-2 in cAMPstimulated aquaporin 2 translocation in renal collecting duct cells. J. Cell Sci. 115, 3667-3674. doi: 10.1242/jcs.00053

Graziani, G., Pini, D., Oldani, S., Cucchiari, D., Podestá, M. A., and Badalamenti, S. (2014). Renal dysfunction in acute congestive heart failure: a common problem for cardiologists and nephrologists. Heart Fail. Rev. 19, 699-708. doi: 10.1007/s10741-013-9416-5

Gross, P. (2012). Clinical management of SIADH. Ther. Adv. Endocrinol. Metab. 3, 61-73. doi: 10.1177/2042018812437561

Hadrup, N., Petersen, J. S., Praetorius, J., Meier, E., Graebe, M., Brønd, L., et al. (2004). Opioid receptor-like 1 stimulation in the collecting duct induces aquaresis through vasopressin-independent aquaporin-2 downregulation. Am. J. Physiol. Renal Physiol. 287, F160-F168. doi: 10.1152/ajprenal. 00329.2003

Han, J. S., Maeda, Y., Ecelbarger, C., and Knepper, M. A. (1994). Vasopressinindependent regulation of collecting duct water permeability. Am. J. Physiol. 266, F139-F146.

Hao, C. M., and Breyer, M. D. (2008). Physiological regulation of prostaglandins in the kidney. Annu. Rev. Physiol. 70, 357-377. doi: 10.1146/annurev.physiol.70.113006.100614

Hara, M., Ma, T., and Verkman, A. S. (2002). Selectively reduced glycerol in skin of aquaporin-3-deficient mice may account for impaired skin hydration, elasticity, and barrier recovery. J. Biol. Chem. 277, 46616-46621. doi: 10.1074/jbc.M209003200 
Hara-Chikuma, M., and Verkman, A. S. (2006). Aquaporin-1 facilitates epithelial cell migration in kidney proximal tubule. J. Am. Soc. Nephrol. 17, 39-45. doi: 10.1681/ASN.2005080846

Hara-Chikuma, M., Sohara, E., Rai, T., Ikawa, M., Okabe, M., Sasaki, S., et al. (2005). Progressive adipocyte hypertrophy in aquaporin-7-deficient mice: adipocyte glycerol permeability as a novel regulator of fat accumulation. J. Biol. Chem. 280, 15493-15496. doi: 10.1074/jbc.C500028200

Hasegawa, H., Ma, T., Skach, W., Matthay, M. A., and Verkman, A. S. (1994). Molecular cloning of a mercurial-insensitive water channel expressed in selected water-transporting tissues. J. Biol. Chem. 269, 5497-5500.

Hasler, U. (2011). An example of functional interaction between NFAT5/TonEBP and nuclear factor-kappaB by hypertonic stress: aquaporin- 2 transcription. Cell Cycle 10, 364-365. doi: 10.4161/cc.10.3.14520

Hasler, U., Jeon, U. S., Kim, J. A., Mordasini, D., Kwon, H. M., Féraille, E., et al. (2006). Tonicity-responsive enhancer binding protein is an essential regulator of aquaporin-2 expression in renal collecting duct principal cells. J. Am. Soc. Nephrol. 17, 1521-1531. doi: 10.1681/ASN.2005121317

Hasler, U., Leroy, V., Jeon, U. S., Bouley, R., Dimitrov, M., Kim, J. A., et al. (2008a). NF-kappaB modulates aquaporin-2 transcription in renal collecting duct principal cells. J. Biol. Chem. 283, 28095-28105. doi: 10.1074/jbc.M708350200

Hasler, U., Nunes, P., Bouley, R., Lu, H. A., Matsuzaki, T., and Brown, D. (2008b). Acute hypertonicity alters aquaporin-2 trafficking and induces a MAPKdependent accumulation at the plasma membrane of renal epithelial cells. $J$. Biol. Chem. 283, 26643-26661. doi: 10.1074/jbc.M801071200

Hatae, N., Sugimoto, Y., and Ichikawa, A. (2002). Prostaglandin receptors: advances in the study of EP3 receptor signaling. J. Biochem. 131, 781-784. doi: 10.1093/oxfordjournals.jbchem.a003165

Hayashi, M., Sasaki, S., Tsuganezawa, H., Monkawa, T., Kitajima, W., Konishi, K., et al. (1994). Expression and distribution of aquaporin of collecting duct are regulated by vasopressin V2 receptor in rat kidney. J. Clin. Invest. 94, 1778-1783. doi: 10.1172/JCI117525

He, X., Tse, C. M., Donowitz, M., Alper, S. L., Gabriel, S. E., and Baum, B. J. (1997). Polarized distribution of key membrane transport proteins in the rat submandibular gland. Pflugers Arch. 433, 260-268. doi: 10.1007/s004240050276

Hébert, R. L., Jacobson, H. R., and Breyer, M. D. (1990). PGE2 inhibits AVPinduced water flow in cortical collecting ducts by protein kinase $\mathrm{C}$ activation. Am. J. Physiol.. Renal Physiol. 259, F318-F325.

Heinke, F., and Labudde, D. (2012). Membrane protein stability analyses by means of protein energy profiles in case of nephrogenic diabetes insipidus. Comput. Math. Methods Med. 2012:790281. doi: 10.1155/2012/790281

Henn, V., Edemir, B., Stefan, E., Wiesner, B., Lorenz, D., Theilig, F., et al. (2004). Identification of a novel A-kinase anchoring protein 18 isoform and evidence for its role in the vasopressin-induced aquaporin-2 shuttle in renal principal cells. J. Biol. Chem. 279, 26654-26665. doi: 10.1074/jbc. M312835200

Hibuse, T., Maeda, N., Funahashi, T., Yamamoto, K., Nagasawa, A., Mizunoya, W., et al. (2005). Aquaporin 7 deficiency is associated with development of obesity through activation of adipose glycerol kinase. Proc. Natl. Acad. Sci. U.S.A. 102, 10993-10998. doi: 10.1073/pnas.0503291102

Hirji, M. R., and Mucklow, J. C. (1991). Transepithelial water movement in response to carbamazepine, chlorpropamide and demeclocycline in toad urinary bladder. Br. J. Pharmacol. 104, 550-553. doi: 10.1111/j.14765381.1991.tb12466.X

Hiroaki, Y., Tani, K., Kamegawa, A., Gyobu, N., Nishikawa, K., Suzuki, H., et al. (2006). Implications of the aquaporin-4 structure on array formation and cell adhesion. J. Mol. Biol. 355, 628-639. doi: 10.1016/j.jmb.2005.10.081

Ho, J. D., Yeh, R., Sandstrom, A., Chorny, I., Harries, W. E., Robbins, R. A., et al. (2009). Crystal structure of human aquaporin 4 at $1.8 \mathrm{~A}$ and its mechanism of conductance. Proc. Natl. Acad. Sci. U.S.A. 106, 7437-7442. doi: 10.1073/pnas.0902725106

Hocherl, K., Schmidt, C., Kurt, B., and Bucher, M. (2010). Inhibition of NF-kappaB ameliorates sepsis-induced downregulation of aquaporin-2/V2 receptor expression and acute renal failure in vivo. Am. J. Physiol. Renal Physiol. 298, F196-F204. doi: 10.1152/ajprenal.90607.2008

Hoffert, J. D., Fenton, R. A., Moeller, H. B., Simons, B., Tchapyjnikov, D., McDill, B. W., et al. (2008). Vasopressin-stimulated Increase in Phosphorylation at Ser269 potentiates plasma membrane retention of aquaporin-2. J. Biol. Chem. 283, 24617-24627. doi: 10.1074/jbc.M803074200
Hoffert, J. D., Nielsen, J., Yu, M. J., Pisitkun, T., Schleicher, S. M., Nielsen, S., et al. (2007). Dynamics of aquaporin-2 serine-261 phosphorylation in response to short-term vasopressin treatment in collecting duct. Am. J. Physiol. Renal Physiol. 292, F691-F700. doi: 10.1152/ajprenal.00284.2006

Hoffert, J. D., Pisitkun, T., Wang, G., Shen, R. F., and Knepper, M. A. (2006) Quantitative phosphoproteomics of vasopressin-sensitive renal cells: regulation of aquaporin-2 phosphorylation at two sites. Proc. Natl. Acad. Sci. U.S.A. 103, 7159-7164. doi: 10.1073/pnas.0600895103

Houslay, M. D. (2010). Underpinning compartmentalised cAMP signalling through targeted cAMP breakdown. Trends Biochem. Sci. 35, 91-100. doi: 10.1016/j.tibs.2009.09.007

Hozawa, S., Holtzman, E. J., and Ausiello, D. A. (1996). cAMP motifs regulating transcription in the aquaporin 2 gene. Am. J. Physiol. Renal Physiol. 270, C1695-C1702.

Hundsrucker, C., and Klussmann, E. (2008). Direct AKAP-mediated proteinprotein interactions as potential drug targets. Handb. Exp. Pharmacol. 186, 483-503. doi: 10.1007/978-3-540-72843-6_20

Hundsrucker, C., Krause, G., Beyermann, M., Prinz, A., Zimmermann, B., Diekmann, O., et al. (2006a). High-affinity AKAP7delta-protein kinase A interaction yields novel protein kinase A-anchoring disruptor peptides. Biochem. J. 396, 297-306. doi: 10.1042/BJ20051970

Hundsrucker, C., Rosenthal, W., and Klussmann, E. (2006b). Peptides for disruption of PKA anchoring. Biochem. Soc. Trans. 34, 472-473. doi: 10.1042/BST0340472

Ikeda, M., Beitz, E., Kozono, D., Guggino, W. B., Agre, P., and Yasui, M. (2002). Characterization of aquaporin-6 as a nitrate channel in mammalian cells. Requirement of pore-lining residue threonine 63. J. Biol. Chem. 277, 39873-39879. doi: 10.1074/jbc.M207008200

Inoue, T., Nielsen, S., Mandon, B., Terris, J., Kishore, B. K., and Knepper, M. A. (1998). SNAP-23 in rat kidney: colocalization with aquaporin-2 in collecting duct vesicles. Am. J. Physiol. Renal Physiol. 275, F752-F760.

Irarrazabal, C. E., Williams, C. K., Ely, M. A., Birrer, M. J., Garcia-Perez, A., Burg, M. B., et al. (2008). Activator protein-1 contributes to high $\mathrm{NaCl}-$ induced increase in tonicity-responsive enhancer/osmotic response elementbinding protein transactivating activity. J. Biol. Chem. 283, 2554-2563. doi: 10.1074/jbc.M703490200

Ishibashi, K. (2006). Aquaporin superfamily with unusual npa boxes: S-aquaporins (superfamily, sip-like and subcellular-aquaporins). Biochim. Biophys. Acta 52, 20-27.

Ishibashi, K., Imai, M., and Sasaki, S. (2000a). Cellular localization of aquaporin 7 in the rat kidney. Exp. Nephrol. 8, 252-257. doi: 10.1159/000020676

Ishibashi, K., Kuwahara, M., Gu, Y., Kageyama, Y., Tohsaka, A., Suzuki, F., et al. (1997a). Cloning and functional expression of a new water channel abundantly expressed in the testis permeable to water, glycerol, and urea. J. Biol. Chem. 272, 20782-20786.

Ishibashi, K., Kuwahara, M., Kageyama, Y., Sasaki, S., Suzuki, M., and Imai, M. (2000b). "Molecular cloning of a new aquaporin superfamily in mammals," in Molecular Biology and Physiology of Water and Solute Transport, eds S. Hohmann and S. Nielsen (London: Kluwer Academic/Plenum Publishers), 123-126.

Ishibashi, K., Kuwahara, M., Kageyama, Y., Tohsaka, A., Marumo, F., and Sasaki, S. (1997b). Cloning and functional expression of a second new aquaporin abundantly expressed in testis. Biochem. Biophys. Res. Commun. 237, 714-718.

Ishibashi, K., Sasaki, S., Fushimi, K., Uchida, S., Kuwahara, M., Saito, H., et al. (1994). Molecular cloning and expression of a member of the aquaporin family with permeability to glycerol and urea in addition to water expressed at the basolateral membrane of kidney collecting duct cells. Proc. Natl. Acad. Sci. U.S.A. 91, 6269-6273. doi: 10.1073/pnas.91.14.6269

Ishida, N., Hirai, S. I., and Mita, S. (1997). Immunolocalization of aquaporin homologs in mouse lacrimal glands. Biochem. Biophys. Res. Commun. 238, 891-895. doi: 10.1006/bbrc. 1997.7396

Ishikawa, S. (2000). Urinary excretion of aquaporin-2 in pathological states of water metabolism. Ann. Med. 32, 90-93. doi: 10.3109/078538900090 11757

Ishikawa, S. E. (2015). Hyponatremia associated with heart failure: pathological role of vasopressin-dependent impaired water excretion. J.Clin. Med. 4, 933-947. doi: 10.3390/jcm4050933 
Jensen, A. M., Bae, E. H., Fenton, R. A., Nørregaard, R., Nielsen, S., Kim, S. W., et al. (2009). Angiotensin II regulates V2 receptor and pAQP2 during ureteral obstruction. Am. J. Physiol. Renal Physiol. 296, F127-F134. doi: 10.1152/ajprenal.90479.2008

Jensen, A. M., Bae, E. H., Nørregaard, R., Wang, G., Nielsen, S., Schweer, H., et al. (2010). Cyclooxygenase 2 inhibition exacerbates AQP2 and pAQP2 downregulation independently of V2 receptor abundance in the postobstructed kidney. Am. J. Physiol. Renal Physiol. 298, F941-F950. doi: 10.1152/ajprenal.00605.2009

Jensen, A. M., Li, C., Praetorius, H. A., Nørregaard, R., Frische, S., Knepper, M. A., et al. (2006). Angiotensin II mediates downregulation of aquaporin water channels and key renal sodium transporters in response to urinary tract obstruction. Am. J. Physiol. Renal Physiol. 291, F1021-F1032. doi: 10.1152/ajprenal.00387.2005

Jensen, B. L., Stubbe, J., Hansen, P. B., Andreasen, D., and Skøtt, O. (2001). Localization of prostaglandin E(2) EP2 and EP4 receptors in the rat kidney. Am. J. Physiol. Renal Physiol. 280, F1001-F1009.

Jia, Z., Liu, G., Downton, M., Dong, Z., Zhang, A., and Yang, T. (2012). mPGES-1 deletion potentiates urine concentrating capability after water deprivation. Am. J. Physiol. Renal Physiol. 302, F1005-F1012. doi: 10.1152/ajprenal.00508.2011

Jia, Z., Wang, H., and Yang, T. (2009). Mice lacking mPGES-1 are resistant to lithium-induced polyuria. Am. J. Physiol. Renal Physiol. 297, F1689-F1696. doi: 10.1152/ajprenal.00117.2009

Jin, J. (2015). Nonsteroidal anti-inflammatory drugs. JAMA 314, 1084. doi: 10.1001/jama.2015.9936

Jo, I., Harris, H. W., Amendt-Raduege, A. M., Majewski, R. R., and Hammond, T. G. (1995). Rat kidney papilla contains abundant synaptobrevin protein that participates in the fusion of antidiuretic hormone-regulated water channelcontaining endosomes in vitro. Proc. Natl. Acad. Sci. U.S.A. 92, 1876-1880. doi: 10.1073/pnas.92.6.1876

Jo, I., Ward, D. T., Baum, M. A., Scott, J. D., Coghlan, V. M., Hammond, T. G., et al. (2001). AQP2 is a substrate for endogenous PP2B activity within an inner medullary AKAP-signaling complex. Am. J. Physiol. Renal Physiol. 281, F958-F965.

John, S., and Thuluvath, P. J. (2015). Hyponatremia in cirrhosis: pathophysiology and management. World J. Gastroenterol. 21, 3197-3205. doi: 10.3748/wjg.v21. i11.3197

Jonassen, T. E., Brønd, L., Torp, M., Graebe, M., Nielsen, S., Skøtt, O., et al. (2003). Effects of renal denervation on tubular sodium handling in rats with CBL-induced liver cirrhosis. Am. J. Physiol. Renal Physiol. 284, F555-F563. doi: 10.1152/ajprenal.00258.2002

Jones, S., and Thornton, J. M. (1996). Principles of protein-protein interactions. Proc. Natl. Acad. Sci. U.S.A. 93, 13-20. doi: 10.1073/pnas.93.1.13

Jung, H. J., and Kwon, T. H. (2010). Membrane trafficking of collecting duct water channel protein AQP2 regulated by Akt/AS160. Electrolyte Blood Press. 8, 59-65. doi: 10.5049/EBP.2010.8.2.59

Jung, J. S., Preston, G. M., Smith, B. L., Guggino, W. B., and Agre, P. (1994). Molecular structure of the water channel through aquaporin CHIP. The hourglass model. J. Biol. Chem. 269, 14648-14654.

Kamath, C., Govindan, J., Premawardhana, A. D., Wood, S. J., Adlan, M. A., and Premawardhana, L. D. (2013). Nephrogenic diabetes insipidus partially responsive to oral desmopressin in a subject with lithium-induced multiple endocrinopathy. Clin. Med. 13, 407-410. doi: 10.7861/clinmedicine.13-4-407

Kamsteeg, E. J., Duffield, A. S., Konings, I. B. M., Spencer, J., Pagel, P., Deen, P. M. T., et al. (2007). MAL decreases the internalization of the aquaporin-2 water channel. Proc. Natl. Acad. Sci. U.S.A. 104, 16696-16701. doi: $10.1073 /$ pnas.0708023104

Kamsteeg, E. J., Heijnen, I., van Os, C. H., and Deen, P. M. (2000). The subcellular localization of an aquaporin-2 tetramer depends on the stoichiometry of phosphorylated and nonphosphorylated monomers. J. Biol. Chem. 151, 919-930. doi: 10.1083/jcb.151.4.919

Kamsteeg, E. J., Hendriks, G., Boone, M., Konings, I. B., Oorschot, V., van der Sluijs, P., et al. (2006). Short-chain ubiquitination mediates the regulated endocytosis of the aquaporin-2 water channel. Proc. Natl. Acad. Sci. U.S.A. 103, 18344-18349. doi: 10.1073/pnas.0604073103

Kamsteeg, E. J., Savelkoul, P. J., Hendriks, G., Konings, I. B., Nivillac, N. M., Lagendijk, A. K., et al. (2008). Missorting of the Aquaporin-2 mutant E258K to multivesicular bodies/lysosomes in dominant NDI is associated with its monoubiquitination and increased phosphorylation by $\mathrm{PKC}$ but is due to the loss of E258. Pflugers Arch. 455, 1041-1054. doi: 10.1007/s00424-007-0364-6

Kamsteeg, E. J., Wormhoudt, T. A., Rijss, J. P., van Os, C. H., and Deen, P. M. (1999). An impaired routing of wild-type aquaporin-2 after tetramerization with an aquaporin-2 mutant explains dominant nephrogenic diabetes insipidus. EMBO J. 18, 2394-2400. doi: 10.1093/emboj/18.9.2394

Kang, D. Y., Park, J. I., Cho, W. S., Jeong, M. H., Cho, G. W., Park, H. T., et al. (2004). Identification of vasopressin-induced genes in AQP2-transfected MDCK cells by suppression subtractive hybridization. Biochem. Biophys. Res. Commun. 324, 1234-1241. doi: 10.1016/j.bbrc.2004.09.185

Katsura, T., Gustafson, C. E., Ausiello, D. A., and Brown, D. (1997). Protein kinase A phosphorylation is involved in regulated exocytosis of aquaporin-2 in transfected LLC-PK1 cells. Am. J. Physiol. Renal Physiol. 272, F817-F822.

Katsura, T., Verbavatz, J. M., Farinas, J., Ma, T., Ausiello, D. A., Verkman, A. S., et al. (1995). Constitutive and regulated membrane expression of aquaporin 1 and aquaporin 2 water channels in stably transfected LLC-PK1 epithelial cells. Proc. Natl. Acad. Sci. U.S.A. 92, 7212-7216. doi: 10.1073/pnas.92.16.7212

Katz, V. L., and Bowes, W. A. Jr. (1987). Transient diabetes insipidus and preeclampsia. South. Med. J. 80, 524-525. doi: 10.1097/00007611-19870400000030

Keskin, O., Gursoy, A., Ma, B., and Nussinov, R. (2008). Principles of proteinprotein interactions: what are the preferred ways for proteins to interact? Chem. Rev. 108, 1225-1244. doi: 10.1021/cr040409x

Khairallah, W., Fawaz, A., Brown, E. M., and El-Hajj Fuleihan, G. (2007). Hypercalcemia and diabetes insipidus in a patient previously treated with lithium. Nat. Clin. Pract. Nephrology 3, 397-404. doi: 10.1038/ncpneph0525

Kim, G. H., Choi, N. W., Jung, J. Y., Song, J. H., Lee, C. H., Kang, C. M., et al. (2008). Treating lithium-induced nephrogenic diabetes insipidus with a COX-2 inhibitor improves polyuria via upregulation of AQP2 and NKCC2. Am. J. Physiol. Renal Physiol. 294, F702-F709. doi: 10.1152/ajprenal. 00366.2007

Kim, G. H., Lee, J. W., Oh, Y. K., Chang, H. R., Joo, K. W., Na, K. Y., et al. (2004a). Antidiuretic effect of hydrochlorothiazide in lithium-induced nephrogenic diabetes insipidus is associated with upregulation of aquaporin-2, $\mathrm{Na}-\mathrm{Cl}$ cotransporter, and epithelial sodium channel. J. Am. Soc. Nephrol. 15, 2836-2843. doi: 10.1097/01.ASN.0000143476.93376.04

Kim, H. Y., Choi, H. J., Lim, J. S., Park, E. J., Jung, H. J., Lee, Y. J., et al. (2011a). Emerging role of Akt substrate protein AS160 in the regulation of AQP2 translocation. Am. J. Physiol. Renal Physiol. 301, F151-161.

Kim, S. O., Oh, K. J., Lee, H. S., Ahn, K., Kim, S. W., and Park, K. (2011b). Expression of aquaporin water channels in the vagina in premenopausal women. J. Sex. Med. 8, 1925-1930. doi: 10.1111/j.1743-6109.2011. 02284.x

Kim, S. W., Kim, J. W., Choi, K. C., Ma, S. K., Oh, Y., Jung, J. Y., et al. (2004b). Indomethacin enhances shuttling of aquaporin-2 despite decreased abundance in rat kidney. J. Am. Soc. Nephrol. 15, 2998-3005. doi: 10.1097/01.ASN.0000145877.28811.82

Kishida, K., Kuriyama, H., Funahashi, T., Shimomura, I., Kihara, S., Ouchi, N., et al. (2000). Aquaporin adipose, a putative glycerol channel in adipocytes. J. Biol. Chem. 275, 20896-20902. doi: 10.1074/jbc.M001119200

Kishore, B. K., Carlson, N. G., Ecelbarger, C. M., Kohan, D. E., Müller, C. E., Nelson, R. D., et al. (2015). Targeting renal purinergic signalling for the treatment of lithium-induced nephrogenic diabetes insipidus. Acta physiologica 214, 176-188. doi: 10.1111/apha.12507

Kishore, B. K., Terris, J. M., and Knepper, M. A. (1996). Quantitation of aquaporin2 abundance in microdissected collecting ducts: axial distribution and control by AVP. Am. J. Physiol. 271, F62-F70.

Kishore, B. K., Wade, J. B., Schorr, K., Inoue, T., Mandon, B., and Knepper, M. A. (1998). Expression of synaptotagmin VIII in rat kidney. Am. J. Physiol. Renal Physiol. 275, F131-F142.

Kjaersgaard, G., Madsen, K., Marcussen, N., and Jensen, B. L. (2014). Lithium induces microcysts and polyuria in adolescent rat kidney independent of cyclooxygenase-2. Physiol. Rep. 2:e00202. doi: 10.1002/phy2.202

Klokkers, J., Langehanenberg, P., Kemper, B., Kosmeier, S., von Bally, G., Riethmüller, C., et al. (2009). Atrial natriuretic peptide and nitric oxide signaling antagonizes vasopressin-mediated water permeability in inner medullary collecting duct cells. Am. J. Physiol. Renal Physiol. 297, F693-F703. doi: 10.1152/ajprenal.00136.2009 
Klussmann, E. (2015). Protein-protein interactions of PDE4 family members - Functions, interactions and therapeutic value. Cell Signal. doi: 10.1016/j.cellsig.2015.10.005. [Epub ahead of print].

Klussmann, E., and Rosenthal, W. (2001). Role and identification of protein kinase A anchoring proteins in vasopressin-mediated aquaporin-2 translocation. Kidney Int. 60, 446-449. doi: 10.1046/j.1523-1755.2001.060002446.x

Klussmann, E., and Rosenthal, W. (2008). Protein-protein interactions as new drug targets. Preface. Handb. Exp. Pharmacol. 186, v-vi. doi: 10.1007/978-3-540$72843-6$

Klussmann, E., Maric, K., and Rosenthal, W. (2000). The mechanisms of aquaporin control in the renal collecting duct. Rev. Physiol. Biochem. Pharmacol. 141, 33-95. doi: 10.1007/BFb0119577

Klussmann, E., Maric, K., Wiesner, B., Beyermann, M., and Rosenthal, W. (1999). Protein kinase A anchoring proteins are required for vasopressin-mediated translocation of aquaporin-2 into cell membranes of renal principal cells. J. Biol. Chem. 274, 4934-4938. doi: 10.1074/jbc.274.8.4934

Klussmann, E., Tamma, G., Lorenz, D., Wiesner, B., Maric, K., Hofmann, F., et al. (2001). An inhibitory role of Rho in the vasopressin-mediated translocation of aquaporin-2 into cell membranes of renal principal cells. J. Biol. Chem. 276, 20451-20457. doi: 10.1074/jbc.M010270200

Knoers, N. (1993). "Nephrogenic diabetes insipidus," in GeneReviews(R), eds R. A. Pagon, M. P. Adam, H. H. Ardinger, S. E. Wallace, A. Amemiya, L. J. H. Bean, T. D. Bird, C. T. Fong, H. C. Mefford, R. J. H. Smith, and K. Stephens, (Seattle WA: Pediatr Nephrol), 1146-1152.

Knoers, N. V., and Deen, P. M. (2001). Molecular and cellular defects in nephrogenic diabetes insipidus. Pediatr. Nephrol. 16, 1146-1152. doi: $10.1007 / \mathrm{s} 004670100051$

Kobayashi, K., and Yasui, M. (2010). Cellular and subcellular localization of aquaporins $1,3,8$, and 9 in amniotic membranes during pregnancy in mice. Cell Tissue Res. 342, 307-316. doi: 10.1007/s00441-010-1065-6

Kortenoeven, M. L., and Fenton, R. A. (2014). Renal aquaporins and water balance disorders. Biochim. Biophys. Acta 1840, 1533-1549. doi: 10.1016/j.bbagen.2013.12.002

Kortenoeven, M. L., Schweer, H., Cox, R., Wetzels, J. F., and Deen, P. M. (2011). Lithium reduces aquaporin-2 transcription independent of prostaglandins. Am. J. Physiol. Renal Physiol. 302, C131-C140. doi: 10.1152/ajpcell.00197.2011

Kortenoeven, M. L., Schweer, H., Cox, R., Wetzels, J. F., and Deen, P. M. (2012a). Lithium reduces aquaporin-2 transcription independent of prostaglandins. Am. J. Physiol. Cell Physiol. 302, C131-C140. doi: 10.1152/ajpcell.00197.2011

Kortenoeven, M. L., Sinke, A. P., Hadrup, N., Trimpert, C., Wetzels, J. F., Fenton, R. A., et al. (2013). Demeclocycline attenuates hyponatremia by reducing aquaporin-2 expression in the renal inner medulla. Am. J. Physiol. Renal Physiol. 305, F1705-F1718. doi: 10.1152/ajprenal.00723.2012

Kortenoeven, M. L., Trimpert, C., Brand, M. V., Li, Y., Wetzels, J. F., and Deen, P. M. (2012b). In mpkCCD cells, long-term regulation of aquaporin2 by vasopressin occurs independent of protein kinase A and CREB, but may involve Epac. Am. J. Physiol. Renal Physiol. 302, F1395-F1401. doi: 10.1152/ajprenal.00376.2011

Kosinska Eriksson, U., Fischer, G., Friemann, R., Enkavi, G., Tajkhorshid, E., and Neutze, R. (2013). Subangstrom resolution X-ray structure details aquaporin-water interactions. Science 340, 1346-1349. doi: 10.1126/science.12 34306

Krane, C. M., Fortner, C. N., Hand, A. R., McGraw, D. W., Lorenz, J. N., Wert, S. E., et al. (2001a). Aquaporin 5-deficient mouse lungs are hyperresponsive to cholinergic stimulation. Proc. Natl. Acad. Sci. U.S.A. 98, 14114-14119. doi: 10.1073/pnas.231273398

Krane, C. M., Melvin, J. E., Nguyen, H. V., Richardson, L., Towne, J. E., Doetschman, T., et al. (2001b). Salivary acinar cells from aquaporin 5-deficient mice have decreased membrane water permeability and altered cell volume regulation. J. Biol. Chem. 276, 23413-23420. doi: 10.1074/jbc.M008760200

Kuwahara, M., Fushimi, K., Terada, Y., Bai, L., Marumo, F., and Sasaki, S. (1995). cAMP-dependent phosphorylation stimulates water permeability of aquaporincollecting duct water channel protein expressed in Xenopus oocytes. J. Biol. Chem. 270, 10384-10387. doi: 10.1074/jbc.270.18.10384

Kuwahara, M., Iwai, K., Ooeda, T., Igarashi, T., Ogawa, E., Katsushima, Y., et al. (2001). Three families with autosomal dominant nephrogenic diabetes insipidus caused by aquaporin-2 mutations in the C-terminus. Am. J. Hum. Genet. 69, 738-748. doi: $10.1086 / 323643$
Kwon, T. H., Nielsen, J., Masilamani, S., Hager, H., Knepper, M. A., Frokiaer, J., et al. (2002). Regulation of collecting duct AQP3 expression: response to mineralocorticoid. Am. J. Physiol. Renal Physiol. 283, F1403-F1421. doi: 10.1152/ajprenal.00059.2002

Laforenza, U., Scaffino, M. F., and Gastaldi, G. (2013). Aquaporin-10 represents an alternative pathway for glycerol efflux from human adipocytes. PLoS ONE 8:e54474. doi: 10.1371/journal.pone.0054474

Lam, A. K., Ko, B. C., Tam, S., Morris, R., Yang, J. Y., Chung, S. K., et al. (2004). Osmotic response element-binding protein (OREBP) is an essential regulator of the urine concentrating mechanism. J. Biol. Chem. 279, 48048-48054. doi: 10.1074/jbc.M407224200

Lande, M. B., Jo, I., Zeidel, M. L., Somers, M., and Harris, H. W. Jr. (1996). Phosphorylation of aquaporin-2 does not alter the membrane water permeability of rat papillary water channel-containing vesicles. J. Biol. Chem. 271, 5552-5557. doi: 10.1074/jbc.271.10.5552

Lang, P., Gesbert, F., Delespine-Carmagnat, M., Stancou, R., Pouchelet, M., and Bertoglio, J. (1996). Protein kinase A phosphorylation of RhoA mediates the morphological and functional effects of cyclic AMP in cytotoxic lymphocytes. EMBO J. 15, 510-519.

Langeberg, L. K., and Scott, J. D. (2015). Signalling scaffolds and local organization of cellular behaviour. Nat. Rev. Mol. Cell Biol. 16, 232-244. doi: $10.1038 / \mathrm{nrm} 3966$

Larsen, H. S., Ruus, A. K., Schreurs, O., and Galtung, H. K. (2010). Aquaporin 11 in the developing mouse submandibular gland. Eur. J. Oral Sci. 118, 9-13. doi: 10.1111/j.1600-0722.2009.00708.x

Lauridsen, T. G., Vase, H., Starklint, J., Graffe, C. C., Bech, J. N., Nielsen, S., et al. (2010). Increased renal sodium absorption by inhibition of prostaglandin synthesis during fasting in healthy man. A possible role of the epithelial sodium channels. BMC Nephrol. 11, 28. doi: 10.1186/1471-2369-11-28

Le, I. P., Schultz, S., Andresen, B. T., Dewey, G. L., Zhao, P., Listenberger, L., et al. (2012). Aquaporin-2 levels in vitro and in vivo are regulated by VACM-1, a cul 5 gene. Cell. Physiol. Biochem. 30, 1148-1158. doi: 10.1159/000343305

Lee, E. H., Heo, J. S., Lee, H. K., Han, K. H., Kang, H. G., Ha, I. S., et al. (2010). A case of Bartter syndrome type I with atypical presentations. Korean J. Pediatr. 53, 809-813. doi: 10.3345/kjp.2010.53.8.809

Lee, Y. J., and Kwon, T. H. (2009). Ubiquitination of aquaporin-2 in the kidney. Electrolyte Blood Press. 7, 1-4. doi: 10.5049/EBP.2009.7.1.1

Lee, Y. J., Lee, J. E., Choi, H. J., Lim, J. S., Jung, H. J., Baek, M. C., et al. (2011). E3 ubiquitin-protein ligases in rat kidney collecting duct: response to vasopressin stimulation and withdrawal. Am. J. Physiol. Renal Physiol. 301, F883-F896. doi: 10.1152/ajprenal.00117.2011

Li, J. H., Chou, C. L., Li, B., Gavrilova, O., Eisner, C., Schnermann, J., et al. (2009a). A selective EP4 PGE2 receptor agonist alleviates disease in a new mouse model of X-linked nephrogenic diabetes insipidus. J. Clin. Invest. 119, 3115-3126. doi: 10.1172/JCI39680

Li, J., and Verkman, A. S. (2001). Impaired hearing in mice lacking aquaporin-4 water channels. J. Biol. Chem. 276, 31233-31237. doi: 10.1074/jbc.M104368200

Li, S. Z., McDill, B. W., Kovach, P. A., Ding, L., Go, W. Y., Ho, S. N., et al. (2007). Calcineurin-NFATc signaling pathway regulates AQP2 expression in response to calcium signals and osmotic stress. Am. J. Physiol. Renal Physiol. 292, C1606-C1616. doi: 10.1152/ajpcell.00588.2005

Li, W., Zhang, Y., Bouley, R., Chen, Y., Matsuzaki, T., Nunes, P., et al. (2011). Simvastatin enhances aquaporin-2 surface expression and urinary concentration in vasopressin-deficient Brattleboro rats through modulation of Rho GTPase. Am. J. Physiol. Renal Physiol. 301, F309-F318. doi: 10.1152/ajprenal.00001.2011

Li, Y. H., Eto, K., Horikawa, S., Uchida, S., Sasaki, S., Li, X. J., et al. (2009b). Aquaporin-2 regulates cell volume recovery via tropomyosin. Int. J. Biochem. Cell 41, 2466-2476. doi: 10.1016/j.biocel.2009.07.017

Liao, J. K., and Laufs, U. (2005). Pleiotropic effects of statins. Annu. Rev. Pharmacol. Toxicol. 45, 89-118. doi: 10.1146/annurev.pharmtox.45.120403.095748

Liebenhoff, U., and Rosenthal, W. (1995). Identification of Rab3-, Rab5aand synaptobrevin II-like proteins in a preparation of rat kidney vesicles containing the vasopressin-regulated water channel. FEBS Lett. 365, 209-213. doi: 10.1016/0014-5793(95)00476-P

Lin, T. E., Adams, K. F. Jr., and Patterson, J. H. (2014). Potential roles of vaptans in heart failure: experience from clinical trials and considerations 
for optimizing therapy in target patients. Heart Fail. Clin. 10, 607-620. doi: 10.1016/j.hfc.2014.07.009

Liu, K., Kozono, D., Kato, Y., Agre, P., Hazama, A., and Yasui, M. (2005). Conversion of aquaporin 6 from an anion channel to a water-selective channel by a single amino acid substitution. Proc. Natl. Acad. Sci. U.S.A. 102, 2192-2197. doi: 10.1073/pnas.0409232102

Liu, Z., Shen, J., Carbrey, J. M., Mukhopadhyay, R., Agre, P., and Rosen, B. P. (2002). Arsenite transport by mammalian aquaglyceroporins AQP7 and AQP9. Proc. Natl. Acad. Sci. U.S.A. 99, 6053-6058. doi: 10.1073/pnas.092131899

Lloyd, D. J., Hall, F. W., Tarantino, L. M., and Gekakis, N. (2005). Diabetes insipidus in mice with a mutation in aquaporin-2. PLoS Genet. 1:e20. doi: 10.1371/journal.pgen.0010020

López-Rodríguez, C., Antos, C. L., Shelton, J. M., Richardson, J. A., Lin, F., Novobrantseva, T. I., et al. (2004). Loss of NFAT5 results in renal atrophy and lack of tonicity-responsive gene expression. Proc. Natl. Acad. Sci. U.S.A. 101, 2392-2397. doi: 10.1073/pnas.0308703100

Lu, H. A. J., Sun, T. X., Matsuzaki, T., Yi, X. H., Eswara, J., Bouley, R., et al. (2007). Heat shock protein 70 interacts with aquaporin-2 and regulates its trafficking. J. Biol. Chem. 282, 28721-28732. doi: 10.1074/jbc.M611101200

Lu, H., Sun, T. X., Bouley, R., Blackburn, K., McLaughlin, M., and Brown, D. (2004). Inhibition of endocytosis causes phosphorylation (S256)-independent plasma membrane accumulation of AQP2. Am. J. Physiol. Renal Physiol. 286, F233-F243. doi: 10.1152/ajprenal.00179.2003

Ma, T., Frigeri, A., Hasegawa, H., and Verkman, A. S. (1994). Cloning of a water channel homolog expressed in brain meningeal cells and kidney collecting duct that functions as a stilbene-sensitive glycerol transporter. J. Biol. Chem. 269, 21845-21849.

Ma, T., Fukuda, N., Song, Y., Matthay, M. A., and Verkman, A. S. (2000). Lung fluid transport in aquaporin-5 knockout mice. J. Clin. Invest. 105, 93-100. doi: 10.1172/JCI8258

Ma, T., Hara, M., Sougrat, R., Verbavatz, J. M., and Verkman, A. S. (2002). Impaired stratum corneum hydration in mice lacking epidermal water channel aquaporin-3. J. Biol. Chem. 277, 17147-17153. doi: 10.1074/jbc.M2009 25200

Ma, T., Song, Y., Gillespie, A., Carlson, E. J., Epstein, C. J., and Verkman, A. S. (1999). Defective secretion of saliva in transgenic mice lacking aquaporin-5 water channels. J. Biol. Chem. 274, 20071-20074. doi: 10.1074/jbc.274.29.20071

Ma, T., Yang, B., Gillespie, A., Carlson, E. J., Epstein, C. J., and Verkman, A. S. (1997). Generation and phenotype of a transgenic knockout mouse lacking the mercurial-insensitive water channel aquaporin-4. J. Clin. Invest. 100, 957-962. doi: 10.1172/JCI231

Ma, T., Yang, B., Gillespie, A., Carlson, E. J., Epstein, C. J., and Verkman, A. S. (1998). Severely impaired urinary concentrating ability in transgenic mice lacking aquaporin-1 water channels. J. Biol. Chem. 273, 4296-4299. doi: 10.1074/jbc.273.8.4296

Ma, T., Yang, B., Kuo, W. L., and Verkman, A. S. (1996). cDNA cloning and gene structure of a novel water channel expressed exclusively in human kidney: evidence for a gene cluster of aquaporins at chromosome locus 12q13. Genomics 35, 543-550. doi: 10.1006/geno.1996.0396

Maher, B. M., Dhonnchu, T. N., Burke, J. P., Soo, A., Wood, A. E., and Watson, R. W. (2009). Statins alter neutrophil migration by modulating cellular Rho activity-a potential mechanism for statins-mediated pleotropic effects? J. Leukoc. Biol. 85, 186-193. doi: 10.1189/jlb.0608382

Mandon, B., Chou, C. L., Nielsen, S., and Knepper, M. A. (1996). Syntaxin4 is localized to the apical plasma membrane of rat renal collecting duct cells: possible role in aquaporin-2 trafficking. J. Clin. Invest. 98, 906-913. doi: 10.1172/JCI118873

Mandon, B., Nielsen, S., Kishore, B. K., and Knepper, M. A. (1997). Expression of syntaxins in rat kidney. Am. J. Physiol. Renal Physiol. 273, F718-730.

Manley, G. T., Fujimura, M., Ma, T., Noshita, N., Filiz, F., Bollen, A. W., et al. (2000). Aquaporin-4 deletion in mice reduces brain edema after acute water intoxication and ischemic stroke. Nat. Med. 6, 159-163. doi: 10.1038/ 72256

Marples, D., Knepper, M. A., Christensen, E. I., and Nielsen, S. (1995). Redistribution of aquaporin-2 water channels induced by vasopressin in rat kidney inner medullary collecting duct. Am. J. Physiol. 269, C655-C664.

Marples, D., Schroer, T. A., Ahrens, N., Taylor, A., Knepper, M. A., and Nielsen, S. (1998). Dynein and dynactin colocalize with AQP2 water channels in intracellular vesicles from kidney collecting duct. Am. J. Physiol. Renal Physiol. 274, F384-F394.

Marr, N., Bichet, D. G., Hoefs, S., Savelkoul, P. J., Konings, I. B., De Mattia, F., et al. (2002a). Cell-biologic and functional analyses of five new Aquaporin-2 missense mutations that cause recessive nephrogenic diabetes insipidus. J. Am. Soc. Nephrol. 13, 2267-2277. doi: 10.1097/01.ASN.0000027355.41663.14

Marr, N., Bichet, D. G., Lonergan, M., Arthus, M. F., Jeck, N., Seyberth, H. W., et al. (2002b). Heteroligomerization of an Aquaporin-2 mutant with wildtype Aquaporin-2 and their misrouting to late endosomes/lysosomes explains dominant nephrogenic diabetes insipidus. Hum. Mol. Genet. 11, 779-789. doi: 10.1093/hmg/11.7.779

Martín-Belmonte, F., Puertollano, R., Millán, J., and Alonso, M. A. (2000). The MAL proteolipid is necessary for the overall apical delivery of membrane proteins in the polarized epithelial Madin-Darby canine kidney and fischer rat thyroid cell lines. Mol. Biol. Cell 11, 2033-2045. doi: 10.1091/mbc.11.6.2033

Matsumura, Y., Uchida, S., Rai, T., Sasaki, S., and Marumo, F. (1997) Transcriptional regulation of aquaporin-2 water channel gene by cAMP. J. Am. Soc. Nephrol. 8, 861-867.

McDill, B. W., Li, S. Z., Kovach, P. A., Ding, L., and Chen, F. (2006). Congenital progressive hydronephrosis (cph) is caused by an S256L mutation in aquaporin-2 that affects its phosphorylation and apical membrane accumulation. Proc. Natl. Acad. Sci. U.S.A. 103, 6952-6957. doi: 10.1073/pnas.0602087103

McSorley, T., Stefan, E., Henn, V., Wiesner, B., Baillie, G. S., Houslay, M. D., et al. (2006). Spatial organisation of AKAP18 and PDE4 isoforms in renal collecting duct principal cells. Eur. J. Cell Biol. 85, 673-678. doi: 10.1016/j.ejcb.2006.01.005

Merves, M., Bobbitt, B., Parker, K., Kishore, B. K., and Choo, D. (2000). Developmental expression of aquaporin 2 in the mouse inner ear. Laryngoscope 110, 1925-1930. doi: 10.1097/00005537-200011000-00030

Mhatre, A. N., Steinbach, S., Hribar, K., Hoque, A. T., and Lalwani, A. K. (1999). Identification of aquaporin 5 (AQP5) within the cochlea: cDNA cloning and in situ localization. Biochem. Biophys. Res. Commun. 264, 157-162. doi: 10.1006/bbrc. 1999.1323

Mika, D., and Conti, M. (2015). PDE4D phosphorylation: a coincidence detector integrating multiple signaling pathways. Cell Signal. doi: 10.1016/j.cellsig.2015.11.001. [Epub ahead of print].

Mistry, A. C., Mallick, R., Klein, J. D., Weimbs, T., Sands, J. M., and Fröhlich, O. (2009). Syntaxin specificity of aquaporins in the inner medullary collecting duct. Am. J. Physiol. Renal Physiol. 297, F292-F300. doi: 10.1152/ajprenal.00196.2009

Moeller, H. B., MacAulay, N., Knepper, M. A., and Fenton, R. A. (2009). Role of multiple phosphorylation sites in the $\mathrm{COOH}$-terminal tail of aquaporin-2 for water transport: evidence against channel gating. Am. J. Physiol. Renal Physiol. 296, F649-F657. doi: 10.1152/ajprenal.90682.2008

Moeller, H. B., Olesen, E. T., and Fenton, R. A. (2011). Invited Review- regulation of the water channel aquaporin-2 by post-translational modifications. Am. J. Physiol. Renal Physiol. 300, F1062-F1073.

Moeller, H. B., Praetorius, J., Rützler, M. R., and Fenton, R. A. (2010). Phosphorylation of aquaporin-2 regulates its endocytosis and proteinprotein interactions. Proc. Natl. Acad. Sci. U.S.A. 107, 424-429. doi: 10.1073/pnas.0910683107

Moeller, H. B., Rittig, S., and Fenton, R. A. (2013). Nephrogenic diabetes insipidus: essential insights into the molecular background and potential therapies for treatment. Endocr. Rev. 34, 278-301. doi: 10.1210/er.2012-1044

Morath, R., Klein, T., Seyberth, H. W., and Nüsing, R. M. (1999). Immunolocalization of the four prostaglandin E2 receptor proteins EP1, EP2, EP3, and EP4 in human kidney. J. Am. Soc. Nephrol. 10, 1851-1860.

Morello, J. P., Salahpour, A., Laperrière, A., Bernier, V., Arthus, M. F., Lonergan, M., et al. (2000). Pharmacological chaperones rescue cell-surface expression and function of misfolded V2 vasopressin receptor mutants. J. Clin. Invest. 105, 887-895. doi: 10.1172/JCI8688

Morishita, T., Tsutsui, M., Shimokawa, H., Sabanai, K., Tasaki, H., Suda, O., et al. (2005a). Nephrogenic diabetes insipidus in mice lacking all nitric oxide synthase isoforms. Proc. Natl. Acad. Sci. U.S.A. 102, 10616-10621. doi: 10.1073/pnas.0502236102

Morishita, Y., Matsuzaki, T., Hara-chikuma, M., Andoo, A., Shimono, M., Matsuki, A., et al. (2005b). Disruption of aquaporin-11 produces polycystic kidneys 
following vacuolization of the proximal tubule. Mol. Cell. Biol. 25, 7770-7779. doi: 10.1128/MCB.25.17.7770-7779.2005

Morishita, Y., Sakube, Y., Sasaki, S., and Ishibashi, K. (2004). Molecular mechanisms and drug development in aquaporin water channel diseases: aquaporin superfamily (superaquaporins): expansion of aquaporins restricted to multicellular organisms. J. Pharmacol. Sci. 96, 276-279. doi: 10.1254/jphs.FMJ04004X7

Mouillac, B., and Mendre, C. (2014). Vasopressin receptors and pharmacological chaperones: from functional rescue to promising therapeutic strategies. Pharmacol. Res. 83, 74-78. doi: 10.1016/j.phrs.2013.10.007

Mulders, S. M., Bichet, D. G., Rijss, J. P., Kamsteeg, E. J., Arthus, M. F., Lonergan, M., (1998). An aquaporin-2 water channel mutant which causes autosomal dominant nephrogenic diabetes insipidus is retained in the Golgi complex. J. Clin. Invest. 102, 57-66. doi: 10.1172/JCI2605

Mulders, S. M., Knoers, N. V., Van Lieburg, A. F., Monnens, L. A., Leumann, E., Wühl, E., et al. (1997). New mutations in the AQP2 gene in nephrogenic diabetes insipidus resulting in functional but misrouted water channels. J. Am. Soc. Nephrol. 8, 242-248.

Multari, G., Werner, B., Cervoni, M., Lubrano, R., Costantino, F., Demiraj, V., et al. (2001). Peritoneal dialysis in an infant with type 1 diabetes and hyperosmolar coma. J. Endocrinol. Invest. 24, 104-106. doi: 10.1007/ BF03343822

Namba, T., Sugimoto, Y., Negishi, M., Irie, A., Ushikubi, F., Kakizuka, A., et al. (1993). Alternative splicing of C-terminal tail of prostaglandin E receptor subtype EP3 determines G-protein specificity. Nature 365, 166-170. doi: $10.1038 / 365166 \mathrm{a} 0$

Narayen, G., and Mandal, S. N. (2012). Vasopressin receptor antagonists and their role in clinical medicine. Indian J. Endocrinol. Metab. 16, 183-191. doi: $10.4103 / 2230-8210.93734$

Nathan, B. R. (2007). Cerebral correlates of hyponatremia. Neurocrit. Care 6, 72-78. doi: 10.1385/NCC:6:1:72

Nedvetsky, P. I., Stefan, E., Frische, S., Santamaria, K., Wiesner, B., Valenti, G., et al. (2007). A Role of Myosin Vb and Rab11-FIP2 in the Aquaporin-2 Shuttle. Traffic 8, 110-123. doi: 10.1111/j.1600-0854.2006.00508.x

Nedvetsky, P. I., Tabor, V., Tamma, G., Beulshausen, S., Skroblin, P., Kirschner, A., et al. (2010). Reciprocal regulation of aquaporin-2 abundance and degradation by protein kinase A and p38-MAP kinase. J. Am. Soc. Nephrol. 21, 1645-1656. doi: 10.1681/ASN.2009111190

Nedvetsky, P. I., Tamma, G., Beulshausen, S., Valenti, G., Rosenthal, W., and Klussmann, E. (2009). Regulation of aquaporin-2 trafficking. Handb. Exp. Pharmacol. 133-157. doi: 10.1007/978-3-540-79885-9_6

Nejsum, L. N., Elkjaer, M., Hager, H., Frokiaer, J., Kwon, T. H., and Nielsen, S. (2000). Localization of aquaporin-7 in rat and mouse kidney using RT-PCR, immunoblotting, and immunocytochemistry. Biochem. Biophys. Res. Commun. 277, 164-170. doi: 10.1006/bbrc.2000.3638

Nejsum, L. N., Kwon, T. H., Jensen, U. B., Fumagalli, O., Frøkiaer, J., Krane, C. M., et al. (2002). Functional requirement of aquaporin-5 in plasma membranes of sweat glands. Proc. Natl. Acad. Sci. U.S.A. 99, 511-516. doi: 10.1073/pnas.012588099

Nejsum, L. N., Zelenina, M., Aperia, A., Frøkiaer, J., and Nielsen, S. (2005). Bidirectional regulation of AQP2 trafficking and recycling: involvement of AQP2-S256 phosphorylation. Am. J physiol. Renal Physiol. 288, F930-F938. doi: 10.1152/ajprenal.00291.2004

Nelson, R. D., Stricklett, P., Gustafson, C., Stevens, A., Ausiello, D., Brown, D., et al. (1998). Expression of an AQP2 Cre recombinase transgene in kidney and male reproductive system of transgenic mice. Am. J. Physiol. Renal Physiol. 275, C216-C226.

Nielsen, J., Hoffert, J. D., Knepper, M. A., Agre, P., Nielsen, S., and Fenton, R. A. (2008a). Proteomic analysis of lithium-induced nephrogenic diabetes insipidus: mechanisms for aquaporin 2 down-regulation and cellular proliferation. Proc. Natl. Acad. Sci. U.S.A. 105, 3634-3639. doi: 10.1073/pnas. 0800001105

Nielsen, J., Kwon, T. H., Christensen, B. M., Frøkiaer, J., and Nielsen, S. (2008b). Dysregulation of renal aquaporins and epithelial sodium channel in lithiuminduced nephrogenic diabetes insipidus. Semin. Nephrol. 28, 227-244. doi: 10.1016/j.semnephrol.2008.03.002

Nielsen, S., and Agre, P. (1995). The aquaporin family of water channels in kidney. Kidney Int.. 48, 1057-1068. doi: 10.1038/ki.1995.389
Nielsen, S., Frøkiaer, J., Marples, D., Kwon, T. H., Agre, P., and Knepper, M. A. (2002). Aquaporins in the kidney: from molecules to medicine. Physiol. Rev. 82, 205-244. doi: 10.1152/physrev.00024.2001

Nielsen, S., Marples, D., Birn, H., Mohtashami, M., Dalby, N. O., Trimble, M., et al. (1995). Expression of VAMP-2-like protein in kidney collecting duct intracellular vesicles. Colocalization with Aquaporin-2 water channels. J. Clin. Invest. 96, 1834-1844. doi: 10.1172/JCI118229

Nielsen, S., Smith, B. L., Christensen, E. I., Knepper, M. A., and Agre, P. (1993). CHIP28 water channels are localized in constitutively water-permeable segments of the nephron. J. Cell Biol. 120, 371-383. doi: 10.1083/jcb. 120.2.371

Nishimoto, G., Zelenina, M., Li, D., Yasui, M., Aperia, A., Nielsen, S., et al. (1999). Arginine vasopressin stimulates phosphorylation of aquaporin-2 in rat renal tissue. Am. J. Physiol. Renal Physiol. 276, F254-F259.

Noda, Y., Horikawa, S., Furukawa, T., Hirai, K., Katayama, Y., Asai, T., et al. (2004a). Aquaporin-2 trafficking is regulated by PDZ-domain containing protein SPA-1. FEBS Lett. 568, 139-145. doi: 10.1016/j.febslet.2004.05.021

Noda, Y., Horikawa, S., Kanda, E., Yamashita, M., Meng, H., Eto, K., et al. (2008). Reciprocal interaction with G-actin and tropomyosin is essential for aquaporin2 trafficking. J. Biol. Chem. 182, 587-601. doi: 10.1083/jcb.200709177

Noda, Y., Horikawa, S., Katayama, Y., and Sasaki, S. (2004b). Water channel aquaporin-2 directly binds to actin. Biochem. Biophys. Res. Commun. 322, 740-745. doi: 10.1016/j.bbrc.2004.07.195

Noda, Y., Horikawa, S., Katayama, Y., and Sasaki, S. (2005). Identification of a multiprotein ?motor? complex binding to water channel aquaporin-2. Biochem. Biophys. Res. Commun. 330, 1041-1047. doi: 10.1016/j.bbrc.2005.03.079

Nomura, N., Nunes, P., Bouley, R., Nair, A. V., Shaw, S., Ueda, E., et al. (2014). High-throughput chemical screening identifies AG-490 as a stimulator of aquaporin 2 membrane expression and urine concentration. Am. J. Physiol. Cell Physiol. 307, C597-C605. doi: 10.1152/ajpcell.00154.2014

Nørregaard, R., Jensen, B. L., Li, C., Wang, W., Knepper, M. A., Nielsen, S., et al. (2005). COX-2 inhibition prevents downregulation of key renal water and sodium transport proteins in response to bilateral ureteral obstruction. Am. J. Physiol. Renal Physiol. 289, F322-F333. doi: 10.1152/ajprenal.00061.2005

Nørregaard, R., Jensen, B. L., Topcu, S. O., Wang, G., Schweer, H., Nielsen, S., et al. (2010). Urinary tract obstruction induces transient accumulation of COX2-derived prostanoids in kidney tissue. Am. J. Physiol. Regul. Integr. Comp. Physiol. 298, R1017-R1025. doi: 10.1152/ajpregu.00336.2009

Nørregaard, R., Madsen, K., Hansen, P. B., Bie, P., Thavalingam, S., Frøkiær, J., et al. (2011). COX-2 disruption leads to increased central vasopressin stores and impaired urine concentrating ability in mice. Am. J. Physiol. Renal Physiol. 301, F1303-F1313. doi: 10.1152/ajprenal.00665.2010

Noveanu, M., Breidthardt, T., Potocki, M., Reichlin, T., Twerenbold, R., Uthoff, H., et al. (2011). Direct comparison of serial B-type natriuretic peptide and NT-proBNP levels for prediction of short- and long-term outcome in acute decompensated heart failure. Crit. Care 15:R1. doi: 10.1186/cc9398

Ohshiro, K., Yaoita, E., Yoshida, Y., Fujinaka, H., Matsuki, A., Kamiie, J., et al. (2001). Expression and immunolocalization of AQP6 in intercalated cells of the rat kidney collecting duct. Arch. Histol. Cytol. 64, 329-338. doi: 10.1679/aohc.64.329

Okutsu, R., Rai, T., Kikuchi, A., Ohno, M., Uchida, K., Sasaki, S., et al. (2008). AKAP220 colocalizes with AQP2 in the inner medullary collecting ducts. Kidney Int. 74, 1429-1433. doi: 10.1038/ki.2008.402

Olesen, E. T., and Fenton, R. A. (2013). Is There a role for PGE2 in urinary concentration? J. Am. Soc. Nephrol. 24, 169-178. doi: 10.1681/ASN.2012020217

Olesen, E. T., Rützler, M. R., Moeller, H. B., Praetorius, H. A., and Fenton, R. A. (2011). Vasopressin-independent targeting of aquaporin-2 by selective Eprostanoid receptor agonists alleviates nephrogenic diabetes insipidus. Proc. Natl. Acad. Sci. U.S.A. 108, 12949-12954. doi: 10.1073/pnas.1104691108

Otvos, L. Jr., and Wade, J. D. (2014). Current challenges in peptide-based drug discovery. Front. Chem. 2:62. doi: 10.3389/fchem.2014.00062

Pallone, T. L., Edwards, A., Ma, T., Silldorff, E. P., and Verkman, A. S. (2000). Requirement of aquaporin-1 for $\mathrm{NaCl}$-driven water transport across descending vasa recta. J. Clin. Invest. 105, 215-222. doi: 10.1172/JCI8214

Park, E. J., Lim, J. S., Jung, H. J., Kim, E., Han, K. H., and Kwon, T. H. (2013). The role of $70-\mathrm{kDa}$ heat shock protein in dDAVP-induced AQP2 trafficking in kidney collecting duct cells. Am. J. Physiol. Renal Physiol. 304, F958-F971. doi: 10.1152/ajprenal.00469.2012 
Park, Y. J., Baik, H. W., Cheong, H. I., and Kang, J. H. (2014). Congenital nephrogenic diabetes insipidus with a novel mutation in the aquaporin 2 gene. Biomed. Rep. 2, 596-598. doi: 10.3892/br.2014.283

Peters, H. P., Robben, J. H., Deen, P. M., and Wetzels, J. F. (2007). Water in health and disease: new aspects of disturbances in water metabolism. Neth. J. Med. 65, 325-332.

Pisitkun, T., Jacob, V., Schleicher, S. M., Chou, C. L., Yu, M. J., and Knepper, M. A. (2008). Akt and ERK1/2 pathways are components of the vasopressin signaling network in rat native IMCD. Am. J. Physiol. Renal Physiol. 295, F1030-F1043. doi: 10.1152/ajprenal.90339.2008

Preston, G. M., and Agre, P. (1991). Isolation of the cDNA for erythrocyte integral membrane protein of 28 kilodaltons: member of an ancient channel family. Proc. Natl. Acad. Sci. U.S.A. 88, 11110-11114. doi: 10.1073/pnas.88.24. 11110

Preston, G. M., Carroll, T. P., Guggino, W. B., and Agre, P. (1992). Appearance of water channels in Xenopus oocytes expressing red cell CHIP28 protein. Science 256, 385-387. doi: 10.1126/science.256.5055.385

Procino, G., Barbieri, C., Carmosino, M., Rizzo, F., Valenti, G., and Svelto, M. (2010). Lovastatin-induced cholesterol depletion affects both apical sorting and endocytosis of aquaporin-2 in renal cells. Am. J. Physiol. Renal Physiol. 298, F266-F278. doi: 10.1152/ajprenal.00359.2009

Procino, G., Barbieri, C., Carmosino, M., Tamma, G., Milano, S., De Benedictis, L., et al. (2011a). Fluvastatin modulates renal water reabsorption in vivo through increased AQP2 availability at the apical plasma membrane of collecting duct cells. Pflugers Archiv. 462, 753-766. doi: 10.1007/s00424-011-1007-5

Procino, G., Barbieri, C., Tamma, G., De Benedictis, L., Pessin, J. E., Svelto, M., et al. (2008). AQP2 exocytosis in the renal collecting duct - involvement of SNARE isoforms and the regulatory role of Munc18b. J. Cell. Sci. 121, 2097-2106. doi: $10.1242 /$ jcs.022210

Procino, G., Carmosino, M., Marin, O., Brunati, A. M., Contri, A., Pinna, L. A., et al. (2003). Ser-256 phosphorylation dynamics of Aquaporin 2 during maturation from the ER to the vesicular compartment in renal cells. FASEB J. 17, 1886-1888.

Procino, G., Mastrofrancesco, L., Sallustio, F., Costantino, V., Barbieri, C., Pisani, F., et al. (2011b). AQP5 is expressed in type-B intercalated cells in the collecting duct system of the rat, mouse and human kidney. Cell. Physiol. Biochem. 28, 683-692. doi: 10.1159/000335762

Procino, G., Mastrofrancesco, L., Tamma, G., Lasorsa, D. R., Ranieri, M., Stringini, G., et al. (2012). Calcium-sensing receptor and aquaporin 2 interplay in hypercalciuria-associated renal concentrating defect in humans. An in vivo and in vitro study. PLoS ONE 7:e33145. doi: 10.1371/journal.pone.0033145

Procino, G., Milano, S., Carmosino, M., Barbieri, C., Nicoletti, M. C., Li, J. H., et al. (2014). Combination of secretin and fluvastatin ameliorates the polyuria associated with $\mathrm{X}$-linked nephrogenic diabetes insipidus in mice. Kidney Int. 86, 127-138. doi: 10.1038/ki.2014.10

Procino, G., Portincasa, P., Mastrofrancesco, L., Castorani, L., Bonfrate, L., Addabbo, F., et al. (2015). Simvastatin increases AQP2 urinary excretion in hypercholesterolemic patients: a pleiotropic effect of interest for patients with impaired AQP2 trafficking. Clin. Pharmacol. Ther. doi: 10.1002/cpt.305. [Epub ahead of print].

Qureshi, S., Galiveeti, S., Bichet, D. G., and Roth, J. (2014). Diabetes insipidus: celebrating a century of vasopressin therapy. Endocrinology 155, 4605-4621. doi: 10.1210/en.2014-1385

Radin, M. J., Yu, M. J., Stoedkilde, L., Miller, R. L., Hoffert, J. D., Frokiaer, J., et al. (2012). Aquaporin-2 regulation in health and disease. Vet. Clin. Pathol. 41, 455-470. doi: 10.1111/j.1939-165x.2012.00488.x

Raina, S., Preston, G. M., Guggino, W. B., and Agre, P. (1995). Molecular cloning and characterization of an aquaporin cDNA from salivary, lacrimal, and respiratory tissues. J. Biol. Chem. 270, 1908-1912. doi: 10.1074/jbc.270.4.1908

Rao, R., Patel, S., Hao, C., Woodgett, J., and Harris, R. (2010). GSK3beta mediates renal response to vasopressin by modulating adenylate cyclase activity. J. Am. Soc. Nephrol. 21, 428-437. doi: 10.1681/ASN.2009060672

Rao, R., Zhang, M. Z., Zhao, M., Cai, H., Harris, R. C., Breyer, M. D., et al. (2005). Lithium treatment inhibits renal GSK-3 activity and promotes cyclooxygenase 2-dependent polyuria. Am. J. Physiol. Renal Physiol. 288, F642-F649. doi: 10.1152/ajprenal.00287.2004

Regan, J. W. (2003). EP2 and EP4 prostanoid receptor signaling. Life Sci. 74, 143-153. doi: 10.1016/j.lfs.2003.09.031
Rej, S., Shulman, K., Herrmann, N., Harel, Z., Fischer, H. D., Fung, K., et al. (2014). Prevalence and correlates of renal disease in older lithium users: a population-based study. Am. J. Geriatr. Psychiatry 22, 1075-1082. doi: 10.1016/j.jagp.2014.01.015

Ren, H., Yang, B., Molina, P. A., Sands, J. M., and Klein, J. D. (2015). NSAIDs alter phosphorylated forms of AQP2 in the inner medullary tip. PLoS ONE 10:e0141714. doi: 10.1371/journal.pone.0141714

Rice, W. L., Zhang, Y., Chen, Y., Matsuzaki, T., Brown, D., and Lu, H. A. (2012). Differential, Phosphorylation Dependent Trafficking of AQP2 in LLC-PK1 Cells. PLoS ONE 7:e32843. doi: 10.1371/journal.pone.0032843

Rikitake, Y., and Liao, J. K. (2005). Rho GTPases, statins, and nitric oxide. Circ. Res. 97, 1232-1235. doi: 10.1161/01.RES.0000196564.18314.23

Rinschen, M. M., Klokkers, J., Pavenstädt, H., Neugebauer, U., Schlatter, E., and Edemir, B. (2011). Different effects of CsA and FK506 on aquaporin-2 abundance in rat primary cultured collecting duct cells. Pflugers Arch. 462, 611-622. doi: 10.1007/s00424-011-0994-6

Rinschen, M. M., Yu, M. J., Wang, G., Boja, E. S., Hoffert, J. D., Pisitkun, T., et al. (2010). Quantitative phosphoproteomic analysis reveals vasopressin V2receptor-dependent signaling pathways in renal collecting duct cells. Proc. Natl. Acad. Sci. U.S.A. 107, 3882-3887. doi: 10.1073/pnas.0910646107

Robben, J. H., Sze, M., Knoers, N. V., and Deen, P. M. (2006). Rescue of vasopressin V2 receptor mutants by chemical chaperones: specificity and mechanism. Mol. Biol. Cell 17, 379-386. doi: 10.1091/mbc.E05-06-0579

Robben, J. H., Sze, M., Knoers, N. V., and Deen, P. M. (2007). Functional rescue of vasopressin V2 receptor mutants in MDCK cells by pharmacochaperones: relevance to therapy of nephrogenic diabetes insipidus. American journal of physiology. Renal Physiol. 292, F253-F260. doi: 10.1152/ajprenal.00247.2006

Rojek, A., Füchtbauer, E. M., Kwon, T. H., Frokiaer, J., and Nielsen, S. (2006). Severe urinary concentrating defect in renal collecting duct-selective AQP2 conditional-knockout mice. Proc. Natl. Acad. Sci. U.S.A. 103, 6037-6042. doi: 10.1073/pnas.0511324103

Roudier, N., Ripoche, P., Gane, P., Le Pennec, P. Y., Daniels, G., Cartron, J. P., et al. (2002). AQP3 deficiency in humans and the molecular basis of a novel blood group system, GIL. J. Biol. Chem. 277, 45854-45859. doi: 10.1074/jbc.M208999200

Saadoun, S., Papadopoulos, M. C., Hara-Chikuma, M., and Verkman, A. S. (2005). Impairment of angiogenesis and cell migration by targeted aquaporin-1 gene disruption. Nature 434, 786-792. doi: 10.1038/nature03460

Sabolic, I., Katsura, T., Verbavatz, J. M., and Brown, D. (1995). The AQP2 water channel: effect of vasopressin treatment, microtubule disruption, and distribution in neonatal rats. J. Membr. Biol. 143, 165-175. doi: 10.1007/BF00233445

Sanches, T. R., Volpini, R. A., Massola Shimizu, M. H., Braganca, A. C., OshiroMonreal, F., Seguro, A. C., et al. (2012). Sildenafil reduces polyuria in rats with lithium-induced NDI. Am. J. Physiol. Renal Physiol. 302, F216-F225. doi: 10.1152/ajprenal.00439.2010

Sands, J. M., and Blount, M. A. (2014). Novel activators of aquaporin 2 membrane expression for the treatment of nephrogenic diabetes insipidus: less is more. Focus on "High-throughput chemical screening identifies AG-490 as a stimulator of aquaporin 2 membrane expression and urine concentration." Am. J. Physiol. Cell Physiol. 307, C595-C596. doi: 10.1152/ajpcell.001 84.2014

Saparov, S. M., Liu, K., Agre, P., and Pohl, P. (2007). Fast and selective ammonia transport by aquaporin-8. J. Biol. Chem. 282, 5296-5301. doi: 10.1074/jbc.M609343200

Sato, E., Nakamura, T., Amaha, M., Nomura, M., Matsumura, D., Yamagishi, H., et al. (2014). Effect of tolvaptan in patients with chronic kidney disease due to diabetic nephropathy with heart failure. Int. Heart J. 55, 533-538. doi: 10.1536/ihj.14-190

Schächterle, C., Christian, F., Fernandes, J. M., and Klussmann, E. (2015). Screening for Small Molecule Disruptors of AKAP-PKA Interactions. Methods Mol. Biol. 1294, 151-166. doi: 10.1007/978-1-4939-2537-7_12

Schäfer, G., Milic, J., Eldahshan, A., Götz, F., Zühlke, K., Schillinger, C., et al. (2013). Highly functionalized terpyridines as competitive inhibitors of AKAP-PKA interactions. Angew. Chem. Int. Ed Engl. 52, 12187-12191. doi: 10.1002/anie.201304686

Schnermann, J., Chou, C. L., Ma, T., Traynor, T., Knepper, M. A., and Verkman, A. S. (1998). Defective proximal tubular fluid reabsorption in transgenic 
aquaporin-1 null mice. Proc. Natl. Acad. Sci. U.S.A. 95, 9660-9664. doi: 10.1073/pnas.95.16.9660

Shaw, S., and Marples, D. (2002). A rat kidney tubule suspension for the study of vasopressin-induced shuttling of AQP2 water channels. Am. J. Physiol. Renal Physiol. 283, F1160-F1166. doi: 10.1152/ajprenal.00207.2002

Sheng, C., Dong, G., Miao, Z., Zhang, W., and Wang, W. (2015). State-ofthe-art strategies for targeting protein-protein interactions by small-molecule inhibitors. Chem. Soc. Rev. 44, 8238-8259. doi: 10.1039/C5CS00252D

Shi, P. P., Cao, X. R., Qu, J., Volk, K. A., Kirby, P., Williamson, R. A., et al. (2007). Nephrogenic diabetes insipidus in mice caused by deleting $\mathrm{COOH}-$ terminal tail of aquaporin-2. Am. J. Physiol. Renal Physiol. 292, F1334-F1344. doi: 10.1152/ajprenal.00308.2006

Shukla, A., Hager, H., Corydon, T. J., Bean, A. J., Dahl, R., Vajda, Z., et al. (2001). SNAP-25-associated Hrs-2 protein colocalizes with AQP2 in rat kidney collecting duct principal cells. Am. J. Physiol. Renal Physiol. 281, F546-F556.

Sim, J. H., Himmel, N. J., Redd, S. K., Pulous, F. E., Rogers, R. T., Black, L. N., et al. (2014). Absence of PKC-alpha attenuates lithium-induced nephrogenic diabetes insipidus. PLOS ONE 9:e101753. doi: 10.1371/journal.pone.0101753

Simon, H., Gao, Y., Franki, N., and Hays, R. M. (1993). Vasopressin depolymerizes apical F-actin in rat inner medullary collecting duct. Am. J. Physiol. Renal Physiol. 265, C757-C762.

Sinke, A. P., Kortenoeven, M. L., de Groot, T., Baumgarten, R., Devuyst, O., Wetzels, J. F., et al. (2014). Hydrochlorothiazide attenuates lithiuminduced nephrogenic diabetes insipidus independently of the sodiumchloride cotransporter. Am. J. Physiol. Renal Physiol. 306, F525-F533. doi: 10.1152/ajprenal.00617.2013

Skroblin, P., Grossmann, S., Schäfer, G., Rosenthal, W., and Klussmann, E. (2010). Mechanisms of protein kinase a anchoring. Int. Rev. Cell Mol. Biol. 283, 235-330. doi: 10.1016/S1937-6448(10)83005-9

Sohara, E., Rai, T., Miyazaki, J., Verkman, A. S., Sasaki, S., and Uchida, S. (2005). Defective water and glycerol transport in the proximal tubules of AQP7 knockout mice. Am. J. Physiol. Renal Physiol. 289, F1195-F1200. doi: 10.1152/ajprenal.00133.2005

Sohara, E., Rai, T., Sasaki, S., and Uchida, S. (2006a). Physiological roles of AQP7 in the kidney: lessons from AQP7 knockout mice. Biochim. Biophys. Acta 1758, 1106-1110. doi: 10.1016/j.bbamem.2006.04.002

Sohara, E., Rai, T., Yang, S. S., Uchida, K., Nitta, K., Horita, S., et al. (2006b). Pathogenesis and treatment of autosomal-dominant nephrogenic diabetes insipidus caused by an aquaporin 2 mutation. Proc. Natl. Acad. Sci. USA. 103, 14217-14222. doi: 10.1073/pnas.0602331103

Sokol, H. W., and Zimmerman, E. A. (1982). The hormonal status of the Brattleboro rat. Ann. N. Y. Acad. Sci. 394, 535-548. doi: 10.1111/j.17496632.1982.tb37468.x

Song, Y., and Verkman, A. S. (2001). Aquaporin-5 dependent fluid secretion in airway submucosal glands. J. Biol. Chem. 276, 41288-41292. doi: 10.1074/jbc.M107257200

Stefan, E., Wiesner, B., Baillie, G. S., Mollajew, R., Henn, V., Lorenz, D., et al. (2007). Compartmentalization of cAMP-dependent signaling by phosphodiesterase-4D is involved in the regulation of vasopressin-mediated water reabsorption in renal principal cells. J. Am. Soc. Nephrol. 18, 199-212. doi: 10.1681/ASN.2006020132

Stødkilde, L., Nørregaard, R., Fenton, R. A., Wang, G., Knepper, M. A., and Frokiær, J. (2011). Bilateral ureteral obstruction induces early downregulation and redistribution of AQP2 and phosphorylated AQP2. Am. J. Physiol. Renal Physiol. 301, F226-F235. doi: 10.1152/ajprenal.00664.2010

Storm, R., Klussmann, E., Geelhaar, A., Rosenthal, W., and Maric, K. (2003). Osmolality and solute composition are strong regulators of AQP2 expression in renal principal cells. Am. J. Physiol. Renal Physiol. 284, F189-F198. doi: 10.1152/ajprenal.00245.2002

Strange, K., Willingham, M. C., Handler, J. S., and Harris, H. W. Jr. (1988). Apical membrane endocytosis via coated pits is stimulated by removal of antidiuretic hormone from isolated, perfused rabbit cortical collecting tubule. J. Membrane Biol. 103, 17-28. doi: 10.1007/BF01871929

Sugimoto, Y., and Narumiya, S. (2007). Prostaglandin E receptors. J. Biol. Chem. 282, 11613-11617. doi: 10.1074/jbc.R600038200

Sugimoto, Y., Namba, T., Honda, A., Hayashi, Y., Negishi, M., Ichikawa, A., et al. (1992). Cloning and expression of a cDNA for mouse prostaglandin E receptor EP3 subtype. J. Biol. Chem. 267, 6463-6466.
Sugimoto, Y., Namba, T., Shigemoto, R., Negishi, M., Ichikawa, A., and Narumiya, S. (1994). Distinct cellular localization of mRNAs for three subtypes of prostaglandin E receptor in kidney. Am. J. Physiol. Renal Physiol. 266, F823-F828.

Sun, T. X., Van Hoek, A., Huang, Y., Bouley, R., McLaughlin, M., and Brown, D. (2002). Aquaporin-2 localization in clathrin-coated pits: inhibition of endocytosis by dominant-negative dynamin. Am. J. Physiol. Renal Physiol. 282, F998-F1011. doi: 10.1152/ajprenal.00257.2001

Szaszák, M., Christian, F., Rosenthal, W., and Klussmann, E. (2008). Compartmentalized cAMP signalling in regulated exocytic processes in non-neuronal cells. Cell. Signal. 20, 590-601. doi: 10.1016/j.cellsig.2007. 10.020

Szygula-Jurkiewicz, B., Szczurek, W., Król, B., and Zembala, M. (2014). The role of statins in chronic heart failure. Kardiochir. Torakochirurgia Pol. 11, 301-305. doi: 10.5114/kitp.2014.45681

Tajika, Y., Matsuzaki, T., Suzuki, T., Ablimit, A., Aoki, T., Hagiwara, H., et al. (2005). Differential regulation of AQP2 trafficking in endosomes by microtubules and actin filaments. Histochem. Cell Biol. 124, 1-12. doi: 10.1007/s00418-005-0010-3

Tajika, Y., Matsuzaki, T., Suzuki, T., Aoki, T., Hagiwara, H., Kuwahara, M., et al. (2004). Aquaporin-2 is retrieved to the apical storage compartment via early endosomes and phosphatidylinositol 3-kinase-dependent pathway. Endocrinology 145, 4375-4383. doi: 10.1210/en.2004-0073

Takeda, S., Lin, C. T., Morgano, P. G., McIntyre, S. J., and Dousa, T. P. (1991). High activity of low-Michaelis-Menten constant $3^{\prime}, 5^{\prime}$-cyclic adenosine monophosphate-phosphodiesterase isozymes in renal inner medulla of mice with hereditary nephrogenic diabetes insipidus. Endocrinology 129, 287-294. doi: 10.1210/endo-129-1-287

Tamma, G. (2003). cAMP-induced AQP2 translocation is associated with RhoA inhibition through RhoA phosphorylation and interaction with RhoGDI. J. Cell. Sci. 116, 1519-1525. doi: 10.1242/jcs.00355

Tamma, G. (2005). Actin remodeling requires ERM function to facilitate AQP2 apical targeting. J. Cell. Sci. 118, 3623-3630. doi: 10.1242/jcs.02495

Tamma, G., Klussmann, E., Maric, K., Aktories, K., Svelto, M., Rosenthal, W., et al. (2001). Rho inhibits cAMP-induced translocation of aquaporin-2 into the apical membrane of renal cells. Am. J. Physiol. Renal Physiol. 281, F1092-F1101. doi: 10.1152/ajprenal.0091.2001

Tamma, G., Klussmann, E., Procino, G., Svelto, M., Rosenthal, W., and Valenti, G. (2003a). cAMP-induced AQP2 translocation is associated with RhoA inhibition through RhoA phosphorylation and interaction with RhoGDI. J. Cell Sci. 116, 1519-1525. doi: 10.1242/jcs.00355

Tamma, G., Lasorsa, D., Ranieri, M., Mastrofrancesco, L., Valenti, G., and Svelto, M. (2011a). Integrin signaling modulates AQP2 trafficking via Arg-Gly-Asp (RGD) Motif. Cell. Physiol. Biochem. 27, 739-748. doi: 10.1159/000330082

Tamma, G., Procino, G., Mola, M. G., Svelto, M., and Valenti, G. (2008). Functional involvement of Annexin-2 in cAMP induced AQP2 trafficking. Pflugers Arch. 456, 729-736. doi: 10.1007/s00424-008-0453-1

Tamma, G., Procino, G., Svelto, M., and Valenti, G. (2011b). Cell culture models and animal models for studying the patho-physiological role of renal aquaporins. Cell. Mol. Life Sci. 69, 1931-1946. doi: 10.1007/s00018-011-0903-3

Tamma, G., Robben, J. H., Trimpert, C., Boone, M., and Deen, P. M. T. (2010). Regulation of AQP2 localization by Ser256 and S261 phosphorylation and ubiquitination. Am. J. Physiol. Cell Physiol. 300, C636-C646. doi: 10.1152/ajpcell.00433.2009

Tamma, G., Wiesner, B., Furkert, J., Hahm, D., Oksche, A., Schaefer, M., et al. (2003b). The prostaglandin E2 analogue sulprostone antagonizes vasopressininduced antidiuresis through activation of Rho. J. Cell. Sci. 116, 3285-3294.

Terris, J., Ecelbarger, C. A., Marples, D., Knepper, M. A., and Nielsen, S. (1995). Distribution of aquaporin-4 water channel expression within rat kidney. Am. J. Physiol. 269, F775-F785.

Thai, T. L., Blount, M. A., Klein, J. D., and Sands, J. M. (2012). Lack of protein kinase C-alpha leads to impaired urine concentrating ability and decreased aquaporin-2 in angiotensin II-induced hypertension. Am. J. Physiol. Renal Physiol. 303, F37-F44. doi: 10.1152/ajprenal.00098.2012

Tian, Y., Sandberg, K., Murase, T., Baker, E. A., Speth, R. C., and Verbalis, J. G. (2000). Vasopressin V2 receptor binding is down-regulated during renal escape from vasopressin-induced antidiuresis. Endocrinology 141, 307-314. doi: 10.1210/en.141.1.307 
Tröger, J., Moutty, M. C., Skroblin, P., and Klussmann, E. (2012). A-kinase anchoring proteins as potential drug targets. Br. J. Pharmacol. 166, 420-433. doi: 10.1111/j.1476-5381.2011.01796.x

Umenishi, F., Narikiyo, T., Vandewalle, A., and Schrier, R. (2006). cAMP regulates vasopressin-induced AQP2 expression via protein kinase Aindependent pathway. Biochim. Biophys. Acta 1758, 1100-1105. doi: 10.1016/j.bbamem.2006.06.001

Umenishi, F., Verbavatz, J. M., and Verkman, A. S. (2000). cAMP regulated membrane diffusion of a green fluorescent protein-aquaporin 2 chimera. Biophys. J. 78, 1024-1035. doi: 10.1016/S0006-3495(00)76661-6

Usta, I. M., Barton, J. R., Amon, E. A., Gonzalez, A., and Sibai, B. M. (1994). Acute fatty liver of pregnancy: an experience in the diagnosis and management of fourteen cases. Am. J. Obstet. Gynecol. 171, 1342-1347. doi: 10.1016/00029378(94)90158-9

Vacca, A., Frigeri, A., Ribatti, D., Nicchia, G. P., Nico, B., Ria, R., et al. (2001). Microvessel overexpression of aquaporin 1 parallels bone marrow angiogenesis in patients with active multiple myeloma. Br. J. Haematol. 113, 415-421. doi: 10.1046/j.1365-2141.2001.02738.x

Valenti, G., Procino, G., Carmosino, M., Frigeri, A., Mannucci, R., Nicoletti, I., et al. (2000). The phosphatase inhibitor okadaic acid induces AQP2 translocation independently from AQP2 phosphorylation in renal collecting duct cells. J Cell Sci. 113(Pt 11), 1985-1992.

Valtin, H., Coffey, A. K., O’Sullivan, D. J., Homma, S., and Dousa, T. P. (1990). Causes of the urinary concentrating defect in mice with nephrogenic diabetes insipidus. Physiol. Bohemoslov. 39, 103-111.

van Balkom, B. W. M., Boone, M., Hendriks, G., Kamsteeg, E. J., Robben, J. H., Stronks, H. C., et al. (2009). LIP5 Interacts with Aquaporin 2 and facilitates its lysosomal degradation. J. Am. Soc. Nephrol. 20, 990-1001. doi: 10.1681/ASN.2008060648

van Balkom, B. W., Hoffert, J. D., Chou, C. L., and Knepper, M. A. (2004). Proteomic analysis of long-term vasopressin action in the inner medullary collecting duct of the Brattleboro rat. Am. J. Physiol. Renal Physiol. 286, F216-F224. doi: 10.1152/ajprenal.00307.2003

van Balkom, B. W., Savelkoul, P. J., Markovich, D., Hofman, E., Nielsen, S., van der Sluijs, P., et al. (2002). The role of putative phosphorylation sites in the targeting and shuttling of the aquaporin-2 water channel. J. Biol. Chem. 277, 41473-41479. doi: 10.1074/jbc.M207525200

Verbalis, J. G. (2006). Whole-body volume regulation and escape from antidiuresis. Am. J. Med. 119, S21-29. doi: 10.1016/j.amjmed.2006.05.004

Verhulst, A., D'Haese, P. C., and De Broe, M. E. (2004). Inhibitors of HMG-CoA reductase reduce receptor-mediated endocytosis in human kidney proximal tubular cells. J. Am. Soc. Nephrol. 15, 2249-2257. doi: 10.1097/01.ASN.0000136778.32499.05

Verkman, A. S., Lencer, W. I., Brown, D., and Ausiello, D. A. (1988). Endosomes from kidney collecting tubule cells contain the vasopressin-sensitive water channel. Nature 333, 268-269. doi: 10.1038/333268a0

Verney, E. B. (1947). The antidiuretic hormone and the factors which determine its release. Proc. R. Soc. Lond. B Biol. Sci 135, 25-106. doi: 10.1098/rspb.1947.0037

Villoutreix, B. O., Kuenemann, M. A., Poyet, J. L., Bruzzoni-Giovanelli, H., Labbé, C., Lagorce, D., et al. (2014). Drug-like protein-protein interaction modulators: challenges and opportunities for drug discovery and chemical biology. Mol. Inform. 33, 414-437. doi: 10.1002/minf.201400040

Vossenkämper, A., Nedvetsky, P. I., Wiesner, B., Furkert, J., Rosenthal, W., and Klussmann, E. (2007). Microtubules are needed for the perinuclear positioning of aquaporin-2 after its endocytic retrieval in renal principal cells. Am. J. Physiol. Cell Physiol. 293, C1129-C1138. doi: 10.1152/ajpcell.00628.2006

Wade, J. B. (2011). Statins affect AQP2 traffic. Am. J. Physiol. Renal Physiol. 301, F308. doi: 10.1152/ajprenal.00248.2011

Wallia, A., Bizhanova, A., Huang, W., Goldsmith, S. L., Gossett, D. R., and Kopp, P. (2013). Acute diabetes insipidus mediated by vasopressinase after placental abruption. J. Clin. Endocrinol. Metab. 98, 881-886. doi: 10.1210/jc.2012-3548

Wang, C. C., Ng, C. P., Shi, H., Liew, H. C., Guo, K., Zeng, Q., et al. (2010). A role for VAMP8/endobrevin in surface deployment of the water channel aquaporin 2. Mol. Cell. Biol. 30, 333-343. doi: 10.1128/MCB.00814-09

Wang, W., Li, C., Summer, S. N., Falk, S., Wang, W., Ljubanovic, D., et al. (2008). Role of AQP1 in endotoxemia-induced acute kidney injury. Am. J. Physiol. Renal Physiol. 294, F1473-F1480. doi: 10.1152/ajprenal.00036.2008
Wells, C. D., Liu, M. Y., Jackson, M., Gutowski, S., Sternweis, P. M., Rothstein, J. D., et al. (2002). Mechanisms for reversible regulation between G13 and Rho exchange factors. J. Biol. Chem. 277, 1174-1181. doi: 10.1074/jbc.M1052 74200

Wesche, D., Deen, P. M., and Knoers, N. V. (2012). Congenital nephrogenic diabetes insipidus: the current state of affairs. Pediatr. Nephrol. 27, 2183-2204. doi: 10.1007/s00467-012-2118-8

Wilson, D. M., Perry, H. O., Sams, W. M. Jr., and Dousa, T. P. (1973). Selective inhibition of human distal tubular function by demeclocycline. Curr. Ther. Res. Clin. Exp. 15, 737-740.

Wilson, J. L., Miranda, C. A., and Knepper, M. A. (2013). Vasopressin and the regulation of aquaporin-2. Clin. Exp. Nephrol. 17, 751-764. doi: 10.1007/s10157-013-0789-5

Wu, H., Chen, L., Zhang, X., Zhou, Q., Li, J. M., Berger, S., Borok, Z., et al. (2013). Aqp5 is a new transcriptional target of Dotla and a regulator of Aqp2. PLoS ONE 8:e53342. doi: 10.1371/journal.pone.0053342

Wu, W., Kitamura, S., Truong, D. M., Rieg, T., Vallon, V., Sakurai, H., et al. (2009). Betal-integrin is required for kidney collecting duct morphogenesis and maintenance of renal function. Am. J. Physiol. Renal Physiol. 297, F210-F217. doi: 10.1152/ajprenal.90260.2008

Wüller, S., Wiesner, B., Löffler, A., Furkert, J., Krause, G., Hermosilla, R., et al. (2004). Pharmacochaperones post-translationally enhance cell surface expression by increasing conformational stability of wild-type and mutant vasopressin V2 receptors. J. Biol. Chem. 279, 47254-47263. doi: 10.1074/jbc.M408154200

Yakata, K., Hiroaki, Y., Ishibashi, K., Sohara, E., Sasaki, S., Mitsuoka, K., et al. (2007). Aquaporin-11 containing a divergent NPA motif has normal water channel activity. Biochim. Biophys. Acta 1768, 688-693. doi: 10.1016/j.bbamem.2006.11.005

Yamaguchi, Y., Katoh, H., Yasui, H., Aoki, J., Nakamura, K., and Negishi, M. (2000). Galpha(12) and galpha(13) inhibit $\mathrm{Ca}(2+)$-dependent exocytosis through Rho/Rho-associated kinase-dependent pathway. J. Neurochem. 75, 708-717. doi: 10.1046/j.1471-4159.2000.0750708.x

Yan, L., Xie, F., Lu, J., Ni, Q., Shi, C., Tang, C., et al. (2015). The treatment of vasopressin V2-receptor antagonists in cirrhosis patients with ascites: a meta-analysis of randomized controlled trials. BMC Gastroenterol. 15:65. doi: 10.1186/s12876-015-0297-z

Yang, B., Gillespie, A., Carlson, E. J., Epstein, C. J., and Verkman, A. S. (2001). Neonatal mortality in an aquaporin-2 knock-in mouse model of recessive nephrogenic diabetes insipidus. J. Biol. Chem. 276, 2775-2779. doi: 10.1074/jbc.M008216200

Yang, B., Song, Y., Zhao, D., and Verkman, A. S. (2005). Phenotype analysis of aquaporin-8 null mice. Am. J. Physiol. Cell Physiol. 288, C1161-C1170. doi: 10.1152/ajpcell.00564.2004

Yang, B., van Hoek, A. N., and Verkman, A. S. (1997). Very high single channel water permeability of aquaporin-4 in baculovirus-infected insect cells and liposomes reconstituted with purified aquaporin-4. Biochemistry 36, 7625-7632. doi: 10.1021/bi970231r

Yasui, M. (2009). pH regulated anion permeability of aquaporin-6. Handb. Exp. Pharmacol. 299-308. doi: 10.1007/978-3-540-79885-9_15

Yasui, M., Hazama, A., Kwon, T. H., Nielsen, S., Guggino, W. B., and Agre, P. (1999a). Rapid gating and anion permeability of an intracellular aquaporin. Nature 402, 184-187.

Yasui, M., Kwon, T. H., Knepper, M. A., Nielsen, S., and Agre, P. (1999b). Aquaporin-6: An intracellular vesicle water channel protein in renal epithelia. Proc. Natl. Acad. Sci. U.S.A. 96, 5808-5813.

Yasui, M., Zelenin, S. M., Celsi, G., and Aperia, A. (1997). Adenylate cyclase-coupled vasopressin receptor activates AQP2 promoter via a dual effect on CRE and AP1 elements. Am. J. Physiol. Renal Physiol. 272, F443-F450.

Yeung, C. H., and Cooper, T. G. (2010). Aquaporin AQP11 in the testis: molecular identity and association with the processing of residual cytoplasm of elongated spermatids. Reproduction 139, 209-216. doi: 10.1530/REP09-0298

Yip, K. P. (2006). Epac-mediated $\mathrm{Ca}(2+)$ mobilization and exocytosis in inner medullary collecting duct. Am. J. Physiol. Renal Physiol. 291, F882-F890. doi: 10.1152/ajprenal.00411.2005 
Yu, M. J., Miller, R. L., Uawithya, P., Rinschen, M. M., Khositseth, S., Braucht, D. W. W., et al. (2009). Systems-level analysis of cell-specific AQP2 gene expression in renal collecting duct. Proc. Natl. Acad. Sci. U.S.A. 106, 2441-2446. doi: 10.1073/pnas.0813002106

Yu, X., Li, F., Klussmann, E., Stallone, J. N., and Han, G. (2014). G protein-coupled estrogen receptor 1 mediates relaxation of coronary arteries via cAMP/PKAdependent activation of MLCP. Am. J. Physiol. Endocrinol. Metab. 307, E398E407. doi: 10.1152/ajpendo.00534.2013

Yui, N., Lu, H. A., Chen, Y., Nomura, N., Bouley, R., and Brown, D. (2013). Basolateral targeting and microtubule-dependent transcytosis of the aquaporin-2 water channel. Am. J. Physiol. Cell Physiol. 304, C38-C48. doi: 10.1152/ajpcell.00109.2012

Zelenina, M., Christensen, B. M., Palmér, J., Nairn, A. C., Nielsen, S., and Aperia, A. (2000). Prostaglandin E(2) interaction with AVP: effects on AQP2 phosphorylation and distribution. Am. J. Physiol. Renal Physiol. 278, F388-F394.

Zelenina, M., Zelenin, S., Bondar, A. A., Brismar, H., and Aperia, A. (2002). Water permeability of aquaporin-4 is decreased by protein kinase $\mathrm{C}$ and dopamine. Am. J. Physiol. Renal Physiol. 283, F309-F318. doi: 10.1152/ajprenal.00260.2001
Zhao, H., Yao, X., Wang, T. X., Jin, W. M., Ji, Q. Q., Yang, X., et al. (2012) PKCalpha regulates vasopressin-induced aquaporin-2 trafficking in mouse kidney collecting duct cells in vitro via altering microtubule assembly. Acta Pharmacol. Sin. 33, 230-236. doi: 10.1038/aps.2011.160

Zwang, N. A., Hoffert, J. D., Pisitkun, T., Moeller, H. B., Fenton, R. A., and Knepper, M. A. (2009). Identification of phosphorylation-dependent binding partners of aquaporin-2 using protein mass spectrometry. J. Proteome Res. 8, 1540-1554. doi: $10.1021 /$ pr800894p

Conflict of Interest Statement: The authors declare that the research was conducted in the absence of any commercial or financial relationships that could be construed as a potential conflict of interest.

Copyright $\odot 2016$ Vukićević, Schulz, Faust and Klussmann. This is an open-access article distributed under the terms of the Creative Commons Attribution License (CC $B Y)$. The use, distribution or reproduction in other forums is permitted, provided the original author(s) or licensor are credited and that the original publication in this journal is cited, in accordance with accepted academic practice. No use, distribution or reproduction is permitted which does not comply with these terms. 